\title{
GABRIEL DE OLIVEIRA RODRIGUES
}

CORPOS EM EVIDÊNCIA

Uma perspectiva sobre os ensaios fotográficos de 'G Magazine' 


\section{GABRIEL DE OLIVEIRA RODRIGUES}

CORPOS EM EVIDÊNCIA

Uma perspectiva sobre os ensaios fotográficos de 'G Magazine'

Dissertação apresentada à Escola de Comunicações e Artes da Universidade de São Paulo, como exigência parcial para obtenção do título de Mestre em Ciências da Comunicação, área de concentração de Estudos dos Meios e da Produção Midiática, sob orientação da Profa. Dra. Dulcilia Helena Schroeder Buitoni.

SÃO PAULO

2007 
GABRIEL DE OLIVEIRA RODRIGUES

CORPOS EM EVIDÊNCIA

Uma perspectiva sobre os ensaios fotográficos de 'G Magazine'

DISSERTAÇÃO DE MESTRADO

UNIVERSIDADE DE SÃO PAULO

ESCOLA DE COMUNICAÇÕES E ARTES

MESTRADO EM CIÊNCIAS DA COMUNICAÇÃO

\author{
BANCA EXAMINADORA
}

Profa. Dra. DULCILIA HELENA SCHROEDER BUITONI orientadora

Departamento de Jornalismo e Editoração

da Escola de Comunicações e Artes da Universidade de São Paulo 
Dedico este trabalho

àqueles que acreditam no respeito pelas diferenças características do ser humano, praticando-o;

àqueles que são diferentes por gostarem dos iguais e têm consciência que esta diferença não os torna piores nem melhores que ninguém;

àqueles que, de alguma forma, se empenham pela construção de uma sociedade menos injusta para com grupos sociais minoritários;

a todos que, em diferentes momentos, contribuíram para a conclusão deste trabalho;

a todos que me são caros, que são pedaços de mim, que sempre me ajudam a trilhar meu caminho, que me servem de inspiração. 
São muitas pessoas a agradecer, pois a elaboração deste trabalho contou com a colaboração de conhecidos, amigos e pessoas que, de uma forma ou de outra, se interessaram pelo desenvolvimento do assunto.

Na fase da elaboração da idéia, agradeço ao Prof. Dr. Roberto Boaventura, co-responsável pelo nascimento do projeto.

A Marcio Zaguetti e Clélia Rejane, pelo incentivo de trazer o projeto para São Paulo.

A Joaquim Antonio, pelo encaminhamento inicial do projeto.

À Profa. Dra. Maria do Socorro Nóbrega, pela acolhida na ECA e pelo imprescindível auxílio na adaptação do projeto.

A meus mestres na USP: Profa. Dra. Jeanne Marie Machado de Freitas e Profa. Dra. Mayra Rodrigues Gomes, cujos conhecimentos foram indispensáveis para a construção deste.

A Eduardo Gorck, pelo auxílio inicial dos recursos técnicos.

A Denise Veiga, Kenedy Bezerra e Rosa Goldgrub, pelas perenes palavras de apoio.

E em especial, às três pessoas que acompanharam e nunca desacreditaram da capacidade deste trabalho: Minha orientadora, Profa. Dra. Dulcilia Helena Schroeder Buitoni, pelo sempre solícito atendimento. Profa. Dra. Rosana de Lima Soares, que estabeleceu meu contato na ECA e cujos conhecimentos ministrados foram de suma importância.

E Ana Maria Fadigas, diretora responsável de $\mathrm{G}$ Magazine, que sempre apoiou a minha iniciativa.

Grato a todos pelo apoio. 
"A mais bela de todas as conquistas é quando os fracos e desencorajados levantam suas cabeças e deixam de crer na força de seus opressores". Bertold Brecht, teatrólogo e escritor alemão. 
RESUMO:

Este trabalho propõe uma visão sobre as fotografias publicadas por $G$ Magazine, revista brasileira voltada para o público gay. A perspectiva é identificar o discurso estruturado na linguagem de 'corpos-signos' do nu masculino. A partir de conceitos sobre a comunicação na contemporaneidade, noções de sexualidade apresentadas por Foucault, Freud e Lacan, e de imagem e fotografia para Dubois, Barthes e Peirce, estabeleceremos o paralelo entre os registros lacanianos e as categorias peirceanas. A disposição anatômica dos corpos-signos constrói um discurso conservador sobre a posição do masculino no sistema, concedendo a este o lugar do exercício e manifestação de poder.

\title{
PALAVRAS-CHAVE
}

G Magazine, mídia segmentada, linguagem, sexualidade, corpo-signo, fotografia.

\begin{abstract}
:
This paper proposes a view on the photography published by $G$ Magazine, a Brazilian magazine focused on the gay public. The perspective is to identify the discourse built on the language of naked male 'body-signs'. Based on concepts about the contemporary communication, notions on sexuality stated by Foucault, Freud and Lacan, and on image and photography by Dubois, Barthes and Peirce, we establish a parallel between Lacan's registers and Peirce's categories. The anatomic disposition of the body-signs constructs a conservative discourse on system's male position, providing the main role of practice and manifestation of power.
\end{abstract}

KEY-WORDS

G Magazine, segmented media, language, sexuality, body-sign, photography. 
Um mosaico social $\quad 14$

A cultura das mídias $\quad 18$

A mídia e o sujeito fragmentado 21

Um perfil de $G$ Magazine $\quad 27$

Um olhar sobre $G$ Magazine $\quad 33$

CAPÍTULO II - DA SEXUALIDADE $\quad 41$

Alguns aspectos acerca da sexualidade 42

Uma revista repleta de prazeres proibidos $\quad 45$

Um público-alvo outsider $\quad 49$

A busca pelo falo faltante $\quad 52$

Os três registros de Lacan $\quad 56$

A instituição imaginária da sociedade 68

\section{CAPÍTULO III - DAS IMAGENS}

72

A estrutura do discurso

O sexo como discurso $\quad 80$

A linguagem fotográfica 86

As fotografias em $G$ Magazine $\quad 90$

A linguagem do sexo: um corpus de corpos 96

O nu masculino como linguagem 104

Um discurso de poder 109

A sociedade do espetáculo 115

O poder do masculino 127

CAPÍTULO IV - DAS CATEGORIAS E DOS REGISTROS 136

As convergências entre Peirce e Lacan 137

O símbolo semiótico e o registro simbólico 143

O índice semiótico e o registro imaginário 146

O ícone semiótico e o registro do Real 150

Um gozo no Real 154

ÚLTIMAS CONSIDERAÇÕES $\quad 163$

Um jeito diferente de dizer a mesma coisa 164

Considerações finais 171

$\begin{array}{ll}\text { LISTA DE FIGURAS } & 174\end{array}$

$\begin{array}{ll}\text { REFERÊNCIAS BIBLIOGRÁFICAS } & 175\end{array}$ 
A idéia para realização deste trabalho nasceu de uma descontraída conversa acerca de um antigo projeto de Mestrado que elaborei, que tinha como base a análise do discurso de uma importante figura política nacional, especialmente da metamorfose semântica pela qual este discurso passou ao longo de pouco mais de uma década. Notando minha pouca excitação ao discorrer sobre o tema, foi-me sugerido que eu trabalhasse com um assunto menos sisudo. À época, como eu prestava serviços para a G Magazine, surgiu jocosamente a idéia de eu analisar as fotografias de homens nus publicadas pela revista.

Mais tarde, encarando o assunto de forma séria, nasceu um projeto de Mestrado abraçado pela USP. Ao longo dos últimos três anos foram horas de estudos, leituras e pesquisas, e o resultado de todo esse trabalho está apresentado nas páginas que seguem.

O texto visa a estabelecer um paralelo entre a linguagem utilizada pela $G$ Magazine, revista brasileira mensal volta para o público homossexual masculino e cujo carro-chefe são os ensaios fotográficos de homens nus, e o discurso estabelecido quanto à posição do masculino no sistema. 
A primeira parte do estudo introduz uma análise geral da conjuntura que constrói o contexto onde estão inseridos o veículo que será analisado, bem como todo o processo de comunicação envolvido. É ponto importante neste momento a construção da cultura e do sujeito na sociedade contemporânea. Será discutido o comportamento da mídia perante este mundo globalizado habitado por indivíduos fragmentados.

Após uma visão geral deste quadro, introduzimos nosso objeto de estudo a G Magazine - neste mosaico, e refletiremos sobre o comportamento do veículo para com a linguagem do que chamaremos de 'corpos-signos' em relação ao seu público-alvo, bem como a importância da espetacularização na sociedade de hoje.

Faz-se mister, então, compreender de que forma o corpo-signo fotográfico é representativo de um discurso. Para tanto, na segunda parte do estudo são examinadas noções do papel que a sexualidade (carro-chefe do sentido atribuído à representação em $G$ Magazine) vem a (ou pode) desempenhar no imaginário do público-leitor. O corpo-signo é manipulado imageticamente visando a atingir o imaginário do receptor no que concerne a esta faceta: a sexualidade.

Nesta parte do trabalho, serão analisadas questões da sexualidade humana a partir de fundamentos psicanalíticos, especialmente chamando a atenção a conceitos e questões comportamentais. Os processos de funcionamento da 
sexualidade, tais como a atuação da pulsão sexual, da libido e o papel do fetiche no imaginário do individuo, auxiliarão no entendimento da construção de um discurso baseado na exposição do corpo.

A terceira parte tem enfoque no estudo da linguagem. Partiremos das noções gerais de discurso para, logo após, concentrarmo-nos no discurso do sexo. Mais adiante, consideraremos peculiaridades sobre a linguagem da fotografia, contando com o apoio de teóricos do assunto. A sociedade do espetáculo, ainda, será relevante para este ponto.

Em seguida, um recorte mais específico da linguagem fotográfica utilizada por G Magazine, com a análise do material fotográfico da revista, publicado entre os anos de 2001 e 2004, a exploração de um discurso cujo corpus é o corpo, e o nu masculino como meio de representação de um discurso de poder e de espetacularização também serão assuntos abordados à luz de teóricos da área. Reflexões acerca da linguagem utilizada por $G$ Magazine em suas páginas buscarão uma interpretação geral do discurso estabelecido pelos ensaios fotográficos publicados pela revista.

Especialmente no que se refere à representação do sexo na sociedade contemporânea e seu reflexo no comportamento do indivíduo, reflexões acerca de 
um homem sem gravidade em busca de um gozo a qualquer preço virão ao encontro da proposta apresentada.

A última parte do texto exibe considerações a respeito da aplicação dos parâmetros apresentados ao longo do trabalho. A aproximação entre campos teóricos discutidos ao longo do estudo será de grande valia neste momento.

Como fechamento do trabalho, seguir-se-ão considerações finais acerca do posicionamento discursivo de $G$ Magazine, identificado pela análise das seqüências imagéticas que compõem os ensaios fotográficos da publicação, do conteúdo adquirido pelos corpos-signos exibidos nas páginas da revista e disseminados junto ao público-leitor. 


\section{CAPÍTULO I DO CONTEXTO}




\section{Um mosaico social.}

O texto que segue tem por objetivo abrir um espaço para considerações sobre representações na mídia na contemporaneidade, face a uma sociedade globalizada constituída de sujeitos fragmentados. Estes pressupostos são retirados do ambiente pós-moderno nos estudos de Humanidades. Este trabalho pretende examinar mais cuidadosamente imagens - fotografias - publicadas por uma revista mensal impressa voltada a um público específico, desde a forma como a linguagem se apresenta até o discurso sustentado por esta linguagem no veículo.

Estudiosos de hoje, especialmente do campo das Humanidades, defendem uma visão de sociedade contemporânea, "pós-moderna", estruturada a partir de uma divisão do contingente humano em grupos de afinidades, formadores de um verdadeiro mosaico de indivíduos de um todo social culturalmente fragmentado. As peças deste mosaico estabelecem a identidade cultural do grupo a partir da ênfase em um traço semelhante entre si e na diferença deste com relação aos demais segmentos sociais, definindo caracteres delineadores a serem aderidos por aqueles que integram o grupo.

Como na representação de um mosaico, estes segmentos fragmentados coexistem, encaixando-se e compondo um mesmo espaço físico - quadro observado especialmente hoje, representado nas 'tribos urbanas' que convivem nas grandes

metrópoles. Esta perspectiva sobre a sociedade vai diretamente de encontro à 
divisão por classes, conforme teoria explanada por Karl Marx e Friedrich Engels em meados do século XIX, especialmente no Manifesto Comunista (1848).

Jesús Martín-Barbero menciona uma "teoria da sociedade-massa", que veio à luz dos intelectuais entre as décadas de 1930/40, mas o autor salienta que esta expressão já se fazia presente no vocabulário de analistas sociais desde os meados do século XIX (MARTÍN-BARBERO 2003:55-6). Luiz Gonzaga Motta nos ajuda a entender melhor como este processo funciona, estabelecendo que a organização de nossa sociedade dá-se na perspectiva da existência de núcleos sociais formados por pessoas com interesses comuns. Segundo o autor,

"a divisão entre classe dominante e classe dominada não corresponde mais às intrincadas relações de produção. O rápido processo de urbanização (...) e, especialmente, o processo de globalização da economia criaram novas instâncias de representação e tornaram as sociedades contemporâneas uma teia de inter-relacionamentos flutuantes" (MOTTA 2002:14).

Assim, cada indivíduo não mais estaria preso unicamente a uma classe, mas manteria relacionamentos flutuantes com diversos grupos, podendo fazer parte de diferentes destes núcleos mencionados por Motta, de acordo com sua interação como sujeito com o meio social. Alguns poucos exemplos poderiam ser ligações com grupos defensores de fundamentos étnicos, político-partidários, comunitários, 
religiosos, esportivos, de orientação sexual, um número sem-fim de fragmentações sociais... Um indivíduo pode socialmente tomar parte em vários destes segmentos. Estes grupos naturalmente vão lutar por sua liberdade e autonomia culturais, buscando na unidade ideológica a base para defender seu espaço e criando, assim, verdadeiras 'marcas registradas' que os diferenciam dos demais fragmentos sociais.

O indivíduo, por poder compor mais de um destes grupos, acaba por se fragmentar, constituído de facetas identificadoras e apresentando traços distintivos de todos os grupos aos quais pertence. É esta uma das principais características do sujeito fragmentado e multifacetado, que veio à luz pelo advento da chamada pós-modernidade, esboçado na vertente dos Estudos Culturais e tão verbalizado por estudiosos como Stuart Hall, dentre outros.

Para este sujeito pós-moderno, fragmentado e multifacetado, torna-se fundamental o estabelecimento de um processo de identificação com um (ou mais) segmento(s) do coletivo social, ao(s) qual(is) ele se associará e do(s) qual(is) será representante no mosaico. Para o segmento social, é importante fixar suas raízes culturais diferenciadoras dos demais grupos, para posterior identificação dos indivíduos com a ideologia, para que o sujeito se sinta mais convicto e seguro e encontre sua posição dentro do grande mosaico como um integrante daquele grupo específico. 
Segundo Marilia Scalzo (2003), os leitores costumam manter uma relação quase passional com suas revistas favoritas. Não é à toa que gostem de andar com elas debaixo do braço, como se fossem uma espécie de emblema ou sinal de identificação. Muito do fascínio deste tipo de publicação vem justamente da capacidade que ele tem de construir fortes laços de empatia com seu público.

Marília Scalzo discute o jornalismo de revista, as técnicas de construção de um texto mais arejado, específico ao gênero, e chama atenção para os elementos básicos da esmerada linguagem visual, tão característica do produto. Neste ponto, a fotografia toma importância especial como linguagem de forte apelo imagético. 


\section{A cultura das mídias.}

É importante salientar a idéia que Luiz Gonzaga Motta traz à tona, enfatizando que a teia de inter-relacionamentos flutuantes que se tornou a sociedade de hoje cria novas instâncias de representação para se comunicar. Esta citação vai ao encontro do que Lucia Santaella chama de cultura das mídias. Em artigo, a autora coloca esta cultura das mídias como um estágio transitório entre a moribunda cultura de massas e a ascendente cultura digital alavancada pela era da informática. Santaella assenta que a cultura das mídias "não se confunde nem com a cultura de massas, de um lado, nem com a cultura virtual ou cibercultura de outro. É, isto sim, uma cultura intermediária, situada entre ambas" (SANTAELLA 2003a:24). A principal característica deste estágio intermediário foi efetuar o papel de transição gradual entre a cultura das massas e a virtual, refletindo diretamente esta transição nos processos comunicacionais de produção, distribuição e consumo de material das mídias.

A teia social de inter-relacionamentos, desta forma, aproveita-se desta cultura das mídias para estabelecer a comunicação entre os indivíduos, não por trazer à tona um novo meio de comunicação, mas sim uma nova forma, um novo processo de codificação de mensagem, estabelecendo uma linguagem, até então atípica, para a construção de um discurso voltado para um consumo cada vez mais específico, cada vez menos massificado. O mosaico social, assim, se mantém como sistema humano, com aglomerados distintos ocupando posições e desempenhando 
funções específicas para o andamento da sociedade. A comunicação desta era virtual, ajustando-se a esta conjuntura social 'pós-moderna', será produzida e distribuída visando mais ao consumo de um fragmento do mosaico específico, direcionada para o modus vivendi do grupo, e menos focada na lógica de um coletivo massificado.

Ainda segundo Santaella, não é o meio o principal agente de modificação cultural, mas, antes, são

"os tipos de signos que circulam nesses meios, os tipos de mensagens e processos de comunicação que neles se engendram os verdadeiros responsáveis não só por moldar o pensamento e a sensibilidade dos seres humanos, mas também por propiciar 0 surgimento de novos ambientes sócio-culturais" (Idem; grifo meu).

Assim, Santaella enfatiza no signo utilizado para se comunicar a verdadeira mola mestra das metamorfoses culturais refletidas na mídia, enfocando a questão da determinação da linguagem como fator central à comunicação e à cultura. Não é a forma física de passagem da mensagem que estabelece a cultura, mas sim o conteúdo desta mensagem veiculada o principal agente de mudanças neste movimento humano.

Então, aqueles grupos sociais emaranhados na teia social contemporânea aproveitam-se deste processo desencadeado pelo advento da cultura das mídias 
para se comunicarem utilizando-se de linguagem específica. Há o uso de signos com peso significante ímpar, peculiar no mosaico determinado por variantes sócioculturais identificadoras do grupo. 


\section{A mídia e o sujeito fragmentado.}

A voracidade da vigente economia neoliberal, capitalista e globalizada, não permitiria que esta forte tendência de mercado da comunicação direcionada a grupos peculiares fosse menosprezada. Com isto, vemos emergir um novo campo, bastante atraente e frutífero aos interesses da lucratividade: a informação voltada a grupos sociais.

Refletindo sobre as funções das mídias, Motta cita que "a política não é a única instância de ação da imprensa. Ela desempenha igualmente funções econômicas, especialmente comerciais, quando estimula, por meio de seus anúncios, o consumo de bens" (MOTTA 2002:15). Comumente na sociedade ocidental, calcada na cultura da exposição (em especial na imagem), as mídias desempenham um papel-chave na disseminação de uma idéia. Isso se dá em decorrência das características facilitadoras de largo alcance, instantaneidade no processo de comunicação e visibilidade que a maioria dos veículos podem oferecer na atualidade, atrativos indispensáveis para se produzir uma boa propaganda, que atinja seu público-alvo consumidor com rapidez e eficiência.

O estímulo ao consumo é forte e lucrativa tendência das mídias, que interferem diretamente no estilo de vida da sociedade. Para Motta, a mídia "tem um papel cultural na medida em que veicula e consolida hábitos, costumes, gostos" (Idem). Em uma sociedade-mosaico, a vida socialmente fragmentada é 
exibida, dentre outras formas, pela veiculação de propaganda direcionada a hábitos, costumes e gostos peculiares, apresentando bens de consumo direcionados a públicos bastante específicos, consolidando aspectos sócio-culturais modeladores e utilizando uma linguagem com a qual o grupo-alvo se identifica.

Assim, uma das formas utilizadas pelos grupos de afinidades sócio-culturais, no sentido de enraizar e fortalecer o tom de uniformidade de seu caráter cultural com relação a outros grupos, dá-se através da produção e veiculação de mídia informativa específica - cujos mentores e mantenedores usualmente são figuras atuantes dos próprios grupos -, por meio da qual se estrutura um elo de comunicação entre cada parte do todo. Por meio deste processo, propagandeia-se a ideologia identificadora do fragmento. As mídias cumprirão, desta forma, um papel de legitimadoras de vários aspectos, desde comportamentais até de tendências de consumo. Estes grupos sociais não serão responsáveis pela criação de novos meios de comunicação, mas, antes, do estabelecimento de uma linguagem - uma cadeia de significantes utilizada por estes meios com públicoalvo específico - identificadora do perfil cultural que caracteriza e serve de caracterizador do grupo, diferenciando-o dos demais que compõem a complexa e fragmentada sociedade pós-moderna.

Atualmente, esta tendência de mercado encontra vários exemplos notáveis. Programas de TV com 'pastores-apresentadores' evangelizando fiéis à distância, 
servindo como protagonistas em uma espécie de 'espetáculo televisivo da fé'. Em horário matinal, apresentadoras ensinam receitas culinárias e dão dicas para tornar o cotidiano doméstico mais prático, estas em um cenário estruturado para reproduzir o ambiente de um lar pequeno-burguês ideal. Atrações nestes moldes têm se tornado cada vez mais numerosas nas grades das TVs abertas.

Na mídia impressa o fenômeno não é diferente. Seguindo uma tendência que teve seu início ainda no século XIX, só fez prosperar no século XX e parece manter o mesmo direcionamento nesta primeira década do século XXI, pode-se constatar hoje um número sem fim de publicações voltadas a grupos sociais específicos. Estes veículos tratarão de assuntos delimitados por um campo semiótico preciso que serve de identificador do fragmento social. Exemplos contemporâneos são as revistas voltadas a admiradores e curiosos (tais como Placar para o esporte, Set para o cinema, Caras para a vida privada dos famosos), a profissionais (Info para a área da informática, Exame para os economistas) e para etnias e faixas etárias (Raça Brasil para os negros, Capricho para as adolescentes), bem como uma série de outros temas de interesse dos mais variados segmentos da complexa sociedade 'pós-moderna'.

Motta salienta que

"a mídia passou a ser a instituição política e ideologicamente mais notável da sociedade, suplantando outros poderes (...) e superando 
instituições poderosas, como a igreja e a escola, na produção e disseminação das ideologias, condicionando tudo à lógica midiática" (MOTTA 2002:16).

O poder da mídia na contemporaneidade é indiscutível, tornando-se esta referencial de credibilidade maior que instituições milenares, profundamente arraigadas na sociedade. A imprensa passa a cumprir o papel de criadora e disseminadora de conhecimentos, ferramenta essencial para o nascimento e manutenção de qualquer sistema sígnico no mundo de hoje, mecanismo indispensável para a manutenção de diferenças culturais entre os grupos que compõem o mosaico social.

Tomaz Tadeu da Silva organizou em livro uma série de ensaios que servem de introdução aos estudos do comportamento na contemporaneidade, por alguns chamada a era da pós-modernidade, sob uma ampla definição da hoje vertente dos Estudos Culturais. Em um destes ensaios, Richard Johnson (2000) esclarece como se dá na prática, de forma generalizada, o processo desencadeado pela imprensa como disseminadora, como ferramenta para legitimação de um sistema sígnico. Citando uma revista voltada ao público adolescente feminino, Johnson explica que este veículo "recolhe e representa alguns elementos das culturas privadas da feminilidade através das quais as jovens vivem suas vidas". Após o recolhimento e o recorte da pauta, que se encaixará nos direcionamentos 
ideológicos do público-alvo, trabalha-se todo esse conjunto de informações e temse como resultado nas bancas a revista,

"um material bruto para milhares de leitoras-garotas que produzem suas próprias re-apropriações dos elementos que foram, anteriormente, tomados de empréstimo de sua cultura vivida e de suas formas de subjetividade" (JOHNSON 2000:47-8).

Este 'material bruto' trazido a público pela revista pretende compreender o modus vivendi, os traços identificadores do sistema de coisas que auxilia o indivíduo (no caso, a adolescente) na composição de sua cultura privada, do seu dia-a-dia, através do que o autor chama de 're-apropriação' do que fora recolhido sobre seus interesses. Haverá, naturalmente um processo de identificação do indivíduo com o discurso do grupo representado no veículo, encaixando este indivíduo no mosaico social, convencendo-o de que ele é parte daquele conjunto. Neste momento, o poder de manipulação daqueles que controlam a comunicação torna-se evidente, e este será mais bem observado analisando-se os tons do discurso de cada veículo.

Toda essa mídia utilizar-se-á de linguagem voltada à defesa da cultura específica do seu público-alvo, constituindo-se num reflexo codificado do imaginário representativo de um coletivo social, enfocando as questões dos costumes, gostos e hábitos de consumo. Desta forma, o veículo constitui-se em molde identificador/formador de características e comportamentos do indivíduo, 
recolhendo da cultura cotidiana privada deste traços pessoais - um material bruto - para ser decodificado e publicado. 0 produto final pretende ser o reflexo do sistema de coisas que compõe o cotidiano cultural do grupo social representado por aquela mídia, devidamente trabalhado para atingir objetivos específicos.

A fragmentação expressa na linguagem utilizada em determinados veículos é tão marcante que a razão de ser da publicação parece ser a satisfação do gosto do leitor. Esta nova tendência determina uma audiência mais selecionada, descaracterizando o clássico modelo de comunicação de massa, baseado no envio de um número limitado de mensagens a uma audiência homogênea.

A multiplicação do conteúdo das mensagens torna a audiência mais seletiva e, ao mesmo tempo, selecionada pelo veículo. A audiência selecionada tende a escolher as mensagens com as quais culturalmente se identifica, aprofundando a sua fragmentação como grupo do mosaico e intensificando tanto o relacionamento do grupo social entre si - pelo desenvolvimento do natural processo de identificação -, como o diálogo entre emissor e receptor. Com este fenômeno, a mídia especificamente voltada a um público-alvo culturalmente diferenciado e delineado por um campo de interesses identificador do segmento na sociedade é fato cada vez mais comum na produção e veiculação de material na área da comunicação. Dentre os vários exemplos desta mídia segmentada temos a G Magazine. 


\section{Um perfil de G Magazine.}

A Fractal Edições Ltda., sediada na cidade de São Paulo, publica material voltado basicamente ao público homossexual masculino em formato de portal eletrônico (G on-line) e revista impressa com periodicidade mensal (G Magazine), utilizando-se de linguagem específica, identificadora do segmento em questão. Nota-se nestes casos aquele mesmo processo mencionado por Richard Johnson, anteriormente abordado em linhas gerais neste trabalho, de recolhimento e recorte de pauta focada nos aspectos culturais do fragmento social, trabalhando todo um conjunto de informações.

Destes dois produtos da editora, em especial a G Magazine tornou-se um dos mais conhecidos empreendimentos no ramo de mídia impressa para público específico deste país, concentrada no mercado de publicações voltadas ao homossexual masculino. A revista é editada ininterruptamente desde outubro de 1997, tendo sempre como manchete uma chamada de capa cujo foco está centrado em um ensaio fotográfico que exibe o nu masculino de - geralmente um protagonista.

Em entrevista exclusiva concedida em julho de 2005 para elaboração deste trabalho, a jornalista Ana Maria Fadigas, diretora responsável pela revista, salienta que "a G, acima de qualquer polêmica, trata de assuntos de interesse do segmento gay", indicando o conteúdo geral da publicação. 
O veículo atualmente é publicado contendo 100 páginas. As edições são compostas por dois ensaios fotográficos (um principal chamado "capa", o outro intercalado com os temas "desejo", "fetiche" e "lolito"), protagonizados por homens que se desnudam frente às câmeras, ocupando aproximadamente 15 páginas seguidas cada. $\mathrm{O}$ ensaio principal compõe o foco da capa da revista desde a sua primeira edição, contendo uma fotografia do protagonista e a chamada principal com o nome e alguma informação pertinente ao modelo e/ou ao ensaio. Outras chamadas, por vezes acompanhadas de imagens em segundo plano, chamam menor atenção a outras matérias contidas naquela edição.

O carro-chefe de G Magazine é, sem dúvida, o material fotográfico. Mas, além dos ensaios, os números da publicação contêm um editorial assinado pela diretora responsável, páginas dedicadas a colunas (social, médica, jurídica, de aconselhamentos), matérias de comportamento e reportagens especiais que versam sobre temas variados (de moda a saúde, de direitos civis a turismo, de produtos e serviços a culinária), mas todos têm em comum o fato de serem foco de interesse de um público-alvo, o homossexual masculino.

Como exemplo, na edição 76 (janeiro de 2004) foram veiculadas matérias como Aos seus pés!, que trata de cuidados específicos para a saúde dos pés com dicas de dermatologistas e centros de estética; Quem tem medo de Dorian Grey?, utilizando-se de paralelo com uma obra de Oscar Wilde para tratar do 
envelhecimento entre os gays; uma entrevista com a atriz Grace Gianoukas intitulada Insana, de terça, quarta, quinta..., na qual a atriz fala de seus espetáculos teatrais e de como encara o público gay; uma reportagem sobre Gerentes de saunas, narrando histórias passadas por profissionais que gerenciam este tipo de estabelecimento voltado especificamente para o público gay; e a matéria de turismo Hot trip to Belo Horizonte, com sugestões de roteiros para gays, lésbicas, bissexuais e transgêneros, contando além das belezas da cidade, programas noturnos voltados a este público.

Além deste conteúdo, a revista também publica páginas exclusivas de material publicitário, geralmente de empresas ou profissionais que prestam serviços voltados às necessidades do segmento específico de leitores. Importante citar neste aspecto o amplo predomínio numérico das propagandas de serviços ligados diretamente à sexualidade, como lançamentos e comércio de filmes eróticos, anúncios de estabelecimentos como saunas masculinas, cinemas pornográficos e agências de namoro e de prostituição atuantes em várias capitais e grandes cidades do interior do país.

Interessante, neste ponto, salientar que o pacote recebido em casa pelos assinantes de G Magazine com a edição mensal não contém absolutamente nenhum indício do seu conteúdo: é um pacote plástico escuro no formato da revista, com uma etiqueta com o nome e endereço do destinatário e uma caixa 
postal como identificador do remetente. O 'prazer proibido' contido ali é escondido do coletivo, protegendo o sujeito-leitor da cobrança social de qualquer ônus pela manifestação do instinto. Ao contrário, nas bancas as edições são expostas usualmente nas prateleiras mais altas, lugar comum de publicações de conteúdo não-indicado a menores de idade -, cobertas apenas por um invólucro plástico transparente.

A equipe responsável pela produção da revista é enxuta, se comparada a outras redações de veículos de maior porte no Brasil. Os últimos números de 2004 trazem a jornalista Ana Maria Fadigas como diretora responsável - situação que se mantém até o momento de elaboração deste trabalho. Ao todo, na sede da revista, na região do Brooklin, em São Paulo, trabalham cerca de 20 pessoas entre editores, assistentes e produtores. À época, o editor-chefe era Jayme Camargo, pai, o editor era Sergio Miguez, editor especial de casting Klifit Pugini, editor de arte Fabiano Spadari, assistente de arte Angélica Pinheiro, e Gláucia Terazzi como produtora editorial, dentre outros.

A lista de colaboradores da revista - pessoas que fazem reportagens ou mantêm colunas, mas que não necessariamente desempenham suas funções junto à redação - alcançava 30 nomes. Dentre estes, alguns que usualmente aparecem na mídia, como o psicólogo e terapeuta Klecius Borges, a transformista Nany People, o colunista social David Brazil e o escritor João Silvério Trevisan. 
Os fotógrafos, profissionais responsáveis pelos enquadramentos e por todas as técnicas de cristalização de uma imagem, são parte importante da equipe. Colaboradores como Alessandra Levtchenko, Batista Lima, Moises Pazianotto, Robert Gomes e Victor Almeida foram destaque na produção das seqüências imagéticas entre 2001 e 2004. Neste cerne, especialmente o Bauer Studio destacase particularmente: em disparado responde pela maioria dos ensaios fotográficos publicados durante este período. No currículo do estúdio constam vários trabalhos publicitários, além de imagens que já estamparam, por exemplo, a capa de revistas de renome como Veja. 


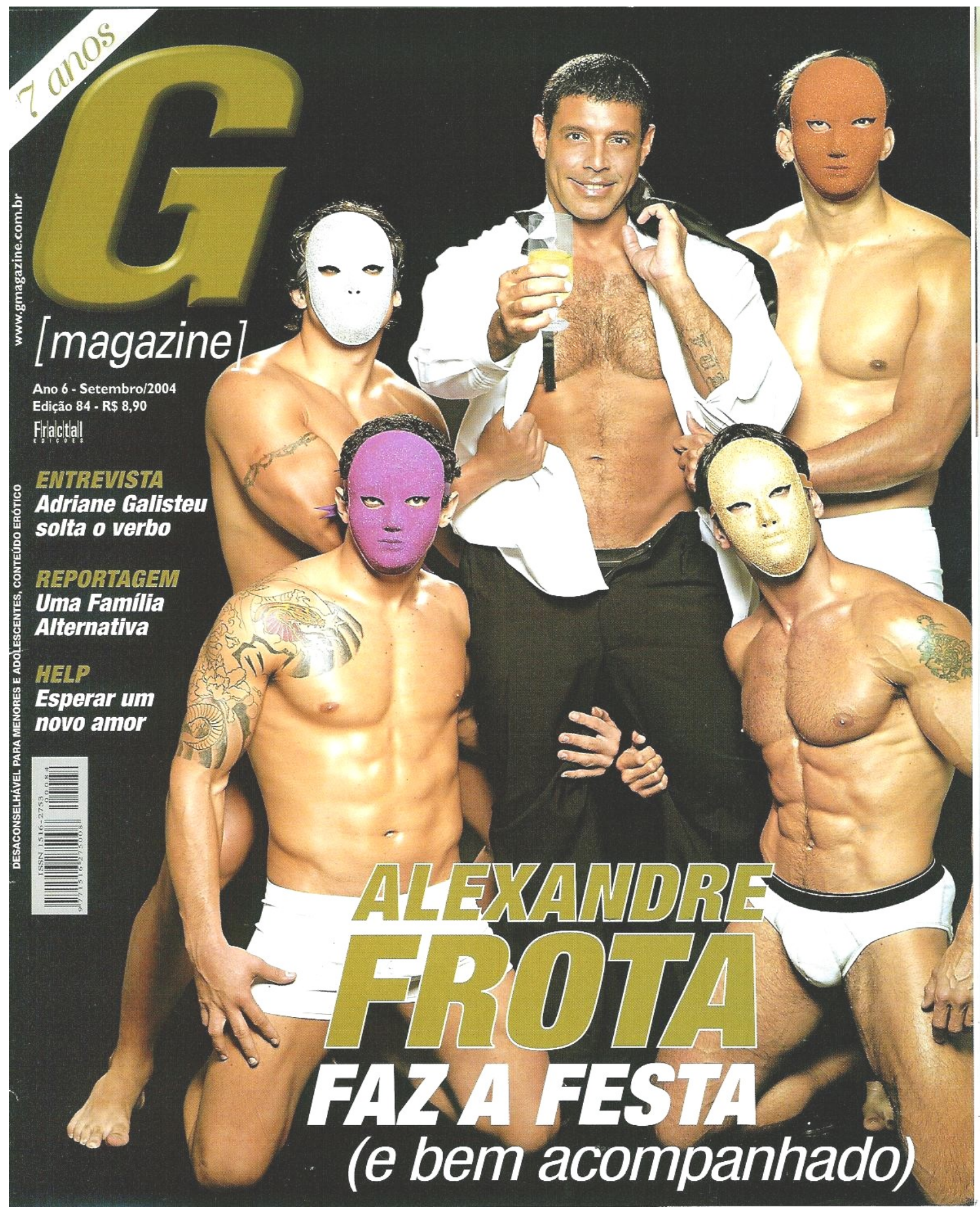

G 84, capa.

Capa da edição 84 de G Magazine, datada de setembro de 2004. Os números deste mês usualmente são festivos, pois comemoram o aniversário da publicação. Na capa em questão, edição comemorativa do sétimo ano da revista. 


\section{Um olhar sobre G Magazine.}

A abertura de espaço na mídia para visibilidade do segmento homossexual, bem como para discussão de vários temas relacionados ao modus vivendi gay contemporâneo e sua interação com o meio social, sem dúvida, tem se intensificado nos últimos tempos. Um fator que influenciou tal visibilidade foram as discussões desencadeadas nos últimos anos junto à população, especialmente pela inserção de personagens homossexuais na teledramaturgia brasileira, alguns inclusive representando na ficção a vivência de relacionamentos homo-afetivos. Como é sabido, no Brasil as telenovelas são um poderoso aspecto cultural formador de opinião, e tais inserções da questão homossexual nas tramas levou a discussão sobre o assunto a grande parte dos lares do país. G Magazine desempenha papel importante para o aumento desta visibilidade aqui no Brasil.

Desta forma, ao observarmos a revista, podemos perceber a existência do processo mencionado por Richard Johnson na elaboração do material que chega aos consumidores. O veículo inicia seu trabalho coletando dados, 'apropriando-se' de formas privadas da cultura, especialmente traços relativos à sexualidade deste grupo, recorta e codifica estes traços da cultura identificadora do fragmento social e os representa num espaço que cumpre o papel de mídia informativa destinada a um definido grupo de leitores. 
A G Magazine já conseguiu levar às bancas como protagonistas de seus ensaios pessoas do mundo do espetáculo, que possuem um determinado grau de visibilidade junto ao grande público e, o mais importante, junto ao segmento especialmente atendido pela revista como público-leitor. Já foram estampados ensaios de personalidades do mundo artístico (atores, cantores, dançarinos), bem como atletas (jogadores de vôlei, de futebol, corredores) e figuras que esporadicamente conquistam certa exposição junto ao grande público (especialmente participantes ou concorrentes de quadros ou 'reality shows' em programas de TV).

No mês de setembro de 2006, a revista alcança a sua edição de número 108, completando seu nono aniversário. É notório, na trajetória desta revista, que a grande maioria dos ensaios fotográficos traz como protagonistas homens com características que expressam uma certa linearidade físico-comportamental.

Por exemplo, em 2004 as 12 edições de G Magazine estamparam em suas capas 13 protagonistas (a edição de outubro conta com dois protagonistas no ensaio principal), sendo destes 11 brancos e dois negros. Destes 13 modelos, dois terços estão na faixa etária abaixo dos 30 anos, nove alcançaram (ou mantiveram) a imagem conhecida na mira do grande público por intermédio de participações, nos últimos anos, na programação das grades de horário veiculadas pela TV aberta - mais especificamente em horários considerados nobres. Todos são 
praticantes freqüentes de algum tipo de atividade física, principal responsável pela manutenção de corpos considerados 'modelos' pelo padrão físico contemporâneo de beleza. Este molde firma-se notadamente nos últimos anos.

Conforme reconhecido por Ana Maria Fadigas, a necessidade de um "famoso" protagonizando o ensaio de capa das edições é crucial para o sucesso do produto. Em nossa entrevista, ela salienta que um marco na história da G Magazine foi a edição 10 (agosto de 1998), cujo ensaio principal teve como modelo Matheus Carrieri, um ator que já participou de produções artísticas - em especial na dramaturgia - de grandes redes de televisão do Brasil.

Os números anteriores, segundo a diretora, não estampavam homens de maior renome junto ao mundo do espetáculo. Até hoje, "as vendas da revista são fortemente impulsionadas pela presença de um 'famoso' na capa", salienta Ana Maria, que enfatiza: "As edições com negros geralmente caem no número de vendas. Há menos ofertas de negros e mais velhos. Quando sai do 'núcleo', metem o pau".

Este "núcleo" corresponde ao perfil anatômico largamente predominante dos protagonistas dos ensaios da revista - homens com menos de 30 anos, brancos, olhos e/ou cabelos claros -, que não corresponde ao estereótipo físico da miscigenação étnica com profundas raízes em povos negros e índios, além dos 
brancos europeus, característica do Brasil. Tal comportamento, a priori, indica o estabelecimento de um perfil étnico-etário como dominante ou preferido. Estes protagonistas olham diretamente para o espectador ao longo do ensaio.

Este conjunto de informações parece indicar um perfil linear básico de indivíduo apto a ocupar o lugar de modelo de capa da G Magazine. Segundo uma avaliação preliminar, além dos preceitos físicos acima citados, a estrutura física robusta e delineada e uma recente exposição pública da imagem em programas populares de televisão parecem diferenciais para a escolha de um protagonista de ensaio fotográfico na revista.

Esta é a linguagem mais vastamente utilizada no carro-chefe da revista: o ensaio fotográfico de capa. Esta linearidade de linguagem, expressa por uma certa constância no arquétipo dos corpos-signos exibidos nas seqüências fotográficas, legitima-se como fatores culturais identificadores do que seria o gosto geral do segmento.

O diferencial de 'famosos' na capa, citado por Ana Maria Fadigas, é uma via de mão-dupla. Há dados importantes sobre a ligação entre a mídia e as pessoas do mundo do espetáculo, bem como sobre a necessidade de exposição freqüente da figura destas pessoas junto aos veículos da mídia. 
Pepe Baeza afirma que grande parte dos personagens do espetáculo midiático acaba por utilizar alguns veículos como extensão de sua área profissional, dando cabo da necessidade de manutenção constante de sua imagem na mídia. Também segundo Baeza, os veículos que cumprem tal papel fazem parte de um ramo da imprensa que se constitui de "publicaciones especializadas en las que lo de menos es el rigor en la valoración crítica, y lo de más la creación y explotación de mitos" (BAEZA 2001:107).

Tal criação e exploração de mitos mencionada pelo autor é positiva para ambos os envolvidos: para o personagem-mito, criando e mantendo estereótipos e, principalmente, a imagem em evidência; e para o veículo, especializado em trabalhar com o imaginário social. O processo de mitificação em torno de alguns signos é parte integrante da cultura do fragmento. Estes 'mitos' criados e/ou mantidos pela linguagem da mídia são verdadeiros referenciais culturais constituintes da identidade do público, firmados pelo posicionamento do signo dentro do sistema de representação apresentado pela mídia.

As seqüências de corpos masculinos nus são os signos escolhidos pela publicação para estabelecer culturalmente sua principal comunicação junto ao seu público-alvo: é a linguagem que a revista utiliza para se aproximar do seu público. 
Aplicando-se as idéias de Lucia Santaella sobre a cultura das mídias, a G Magazine não se destaca por se constituir em um meio inovador, mas pela utilização de um discurso imagético especificamente direcionado a um público. A utilização desta linguagem, com todas as suas características representativas, estrutura o tom discursivo deste veículo, o qual se pretende reflexo cultural do grupo homossexual masculino brasileiro contemporâneo, tornando-se, na prática, um exemplo do processo esclarecido por Santaella.

A capa de todas as edições de G Magazine estampa a expressão "conteúdo erótico". Refletindo leituras a respeito da fotografia e de seu conteúdo, o presente trabalho fará algumas considerações a este respeito.

Para efeito de classificação do conteúdo das fotografias da revista, basearemo-nos nas análises de alguns teóricos da imagem e da fotografia. Reflexões de Roland Barthes em A câmara clara auxiliarão a estabelecermos a fronteira de classificação de fotografias com teor sexual.

Os ensaios fotográficos de G Magazine exibem homens em nu explícito, frontal e com ereção. A aplicação da divisão proposta por Barthes, bem como análises de Arlindo Machado acerca do assunto, possibilitarão uma perspectiva de enquadramento de conteúdo sobre nosso objeto de estudo. 
Surgem, assim, questões angulares: O discurso de G Magazine pode ser considerado transgressor? Que mensagem passa G Magazine? Quais os conceitos agregados a suas formas de expressão?

Para alcançarmos nossos objetivos, trilharemos um caminho de interpretação de imagens publicadas pela revista. Sobre a base da análise das fotografias poder-se-ão aplicar reflexões sobre sexualidade, buscando compreender de que forma mecanismos presentes na estrutura do comportamento humano atuam para a elaboração do direcionamento expresso pela linguagem presente no veículo, compondo o discurso imagético da revista.

O trabalho parte da análise de fotografias que fazem parte de seqüências de ensaios da G Magazine a partir de sua edição de número 40, datada de janeiro de 2001, até a edição 87, publicada em dezembro de 2004. Este período dos quatro primeiros anos do século XXI parece suficiente para exibir neste estudo um quadro bastante atualizado da forma como a revista codifica e publica seu conteúdo. As edições do número 01 ao 39 (que comportam o período entre outubro de 1997 e dezembro de 2000), bem como as posteriores de dezembro de 2004, não serão analisadas neste estudo.

Tal recorte fez-se necessário no intuito de refletir nas páginas deste texto um quadro mais atualizado possível. A visibilidade do segmento homossexual no 
mundo ocidental tem-se intensificado especialmente nos últimos anos. Aqui no Brasil, uma conjuntura de acontecimentos colaborou para o aumento deste processo. O fato de a Prefeitura do Município de São Paulo ter colocado no seu calendário oficial de eventos a anual Parada do Orgulho Gay, que em 2006 foi pelo terceiro ano consecutivo considerada oficialmente a maior do mundo, é prova da importância político-financeira que o público homossexual tem conquistado.

A G Magazine segue este mesmo crescimento acelerado de visibilidade nos últimos anos. Inclusive, durante um determinado período, como resultado de uma parceria da editora com um poderoso grupo de televisão, as edições da revista eram promovidas pelo comparecimento dos protagonistas dos ensaios de capa em um dos mais populares programas de auditório do Brasil. A melhoria do acabamento do produto final publicado pode ser facilmente observada, por exemplo, na qualidade superior da produção do material que chega às bancas. Desde a impressão, passando pela quantidade de páginas até a qualidade das fotografias, a revista apresenta um desenvolvimento notável com relação as suas primeiras edições.

Os resultados deste trabalho poderão contribuir com futuras pesquisas nas áreas de Antropologia, Sociologia, Filosofia da Linguagem, bem como de Economia e Marketing, e principalmente no aprimoramento dos estudos sobre as formas de Comunicação na sociedade contemporânea. 


\section{CAPÍTULO II}

DA SEXUALIDADE 


\section{Alguns aspectos acerca da sexualidade.}

A capa de todas as edições de G Magazine estampa a expressão "conteúdo erótico", alertando o leitor sobre o teor do conteúdo da revista, especialmente dos ensaios fotográficos por ela publicados. As seqüências de fotografias com homens posando nus, entregando seus corpos à contemplação, são marca registrada do veículo, que sempre as expõe como manchete e, portanto, estas configuram-se na parte mais importante de toda a edição.

Na contemporaneidade, o sexo é elemento de valorização de mercadorias, servindo de forte chamariz para o imaginário do grande público. Posto que a $G$ Magazine é revista cujo carro-chefe é a publicação de material com teor sexual visando à manifestação de prazeres, torna-se angular que tenhamos bases norteadoras sobre a sexualidade que possam nos auxiliar durante a análise da linguagem utilizada pelo veículo.

Para Jacques Lacan, importante pensador francês do século $X X$, os caracteres de distinção sexual dados pela Biologia (o masculino e o feminino) são todos secundários, tendo o corpo a simples função de reproduzir pelo reconhecimento do semelhante. Para Lacan, humanamente há um órgão que marca uma diferença (hífen - pênis). Uns o têm (presença), outros não o têm (ausência). O positivo e o negativo não significam suficiência ou carência, são 
apenas marcadores de diferenças. A libido é responsável pela ligação da pulsão sexual com o inconsciente, onde a relação dos sexos é representada.

De acordo com Laplanche e Pontalis, em seu Vocabulário da Psicanálise, para Sigmund Freud a pulsão é o processo dinâmico que consiste numa pressão ou força que faz o organismo tender para um objetivo. A pulsão sempre tem sua fonte numa excitação corporal (estado de tensão), e sua meta é suprimir o estado de tensão que reina na fonte pulsional. Tal meta será atingida no objeto, ou graças a ele (LAPLANCHE \& PONTALIS 1995:394-404).

Dentre as pulsões há a pulsão sexual, que é uma pressão interna que atua num campo muito mais vasto que as atividades sexuais. Sua força-motriz é a libido, suas metas são variáveis, mais especialmente ligadas ao funcionamento das zonas erógenas, e seu objeto é escolhido em função das vicissitudes da história do sujeito.

Desta forma, cada sujeito naturalmente sofre tensões que o impõem a escolha de um objeto para suprimir a pressão interna. Em um estado de excitação corporal do indivíduo, a libido responde ao contato com o objeto e cria uma demanda a ser suprida. Este objeto não é padronizado, sendo escolhido a partir da sucessão instável de imprevisibilidades da vida do sujeito. 
Assim, no que se refere a todo o vasto campo das práticas e das preferências sexuais de cada indivíduo, muitos autores diriam que não há bases psíquicas para se instaurar coletivamente um padrão de comportamento. Cada indivíduo, com base nas vicissitudes da sua história, naturalmente tenderá a um objeto para suprimir sua tensão. Lacan declara que

"a relação sexual fica entregue ao aleatório do campo do Outro. Fica entregue às explicações que se Ihe dêem. Fica entregue à velha de quem se precisa - não é uma fábula vã - para que Daphnis aprenda como se tem que fazer para fazer amor" (LACAN 1998:188).

A moral social vigente, com raízes na religiosidade judaico-cristã, barra o sujeito de sentir determinados prazeres, em especial ligados ao sexo. Práticas sexuais que não visem à reprodução são condenadas como 'desnaturais'. O agente principal desta condenação são doutrinas religiosas conservadoras, que geralmente classifica os atos sexuais que visam ao prazer como pecaminosos.

$\mathrm{Na}$ contrapartida desta moral, o sujeito em meio à civilização continua sentindo a tensão que o leva a uma demanda, e procura formas de suprimir a pressão exercida. Então, a própria sociedade encontrou uma solução para este problema e adaptou meios para que o sujeito possa manifestar os prazeres proibidos sem ter de responder pela infração ao código moral. G Magazine cumpre papel importante neste processo. 


\section{Uma revista repleta de prazeres proibidos.}

Em O mal-estar na civilização, Sigmund Freud examina, dentre outras coisas, as formas como prazeres barrados pela moral social são desfrutados pelo sujeito, mesmo que de formas um tanto mascaradas. O homem, então civilizado por eclipsar instintos impostos pelo tabu (lei), priva seu ego de externar determinadas formas de prazer, condenáveis aos olhos da moral social, especialmente a judaico-cristã vigente na sociedade ocidental.

Com uma vida na qual os instintos devem permanecer ocultos, aliada à consciência da morte e à trajetória de sofrimento imposta pelo viver, dificilmente o homem produziria felicidade. Assim, a busca pela felicidade transforma-se no objetivo para o viver. Por intermédio desta constante procura, ao homem permitese, em meio à civilização, demonstrar somente aquelas felicidades aprovadas socialmente.

Mas, os instintos primitivos continuam latentes e desejados, no entanto, não podem ser apresentados com a mesma intensidade com que são produzidos. O superego - a consciência - tem o papel de punir tais manifestações, punindo também o simples desejo de manifestar alguns prazeres. Estes permanecem pulsantes no sujeito. 
Este sujeito, castrado, privado de seus instintivos sentimentos, busca subterfúgios para suprir as demandas barradas. Hoje, este papel vem sendo desempenhado principalmente pelos meios de comunicação, possibilitando ao sujeito partido inclusive a manifestação de prazer, ainda que não completamente.

A utilização da mídia para manifestação dos prazeres tem sido um caminho viável para a construção discursiva que visa a integrar o sujeito a seu meio social sem que Ihe sejam impostas diretamente as morais civilizantes. Através do aprimoramento constante do conhecimento das necessidades de consumo do sujeito, a mídia produz um discurso sempre pronto e presente para amenizar os sofrimentos cotidianos.

O prazer sexual, sem dúvida, entra no jogo de manipulação da mídia, visando à satisfação da demanda de prazeres barrados do indivíduo. Tendo em vista o rígido código moral judaico-cristão com relação ao assunto, a sociedade ocidental contemporânea encontra na contemplação midiática um meio de manifestação de prazeres, não sendo diretamente imposta ao sujeito contemplador os ônus de tal manifestação.

Neste processo de contemplação prazerosa como meio de suprir demandas barradas pela lei inclui-se a $G$ Magazine, mídia propagadora de 'imagens proibidas', como objeto por intermédio do qual o sujeito castrado poderá 
manifestar prazeres a ele barrados. A revista torna-se a mola propulsora, a ignição que dará partida ao processo de manifestação de um prazer sexual socialmente marcado como fora do padrão moral estabelecido. Este mesmo mecanismo funciona nas revistas que publicam o nu feminino.

O prazer sexual advindo do consumo contemplativo dos ensaios fotográficos publicados pelo veículo poderá ser manifestado sem um ônus social ao sujeito. A publicação, embebida em significação de profundo teor sexual, está diretamente voltada a atingir sua meta, ligada ao funcionamento das zonas erógenas do sujeito-leitor. 


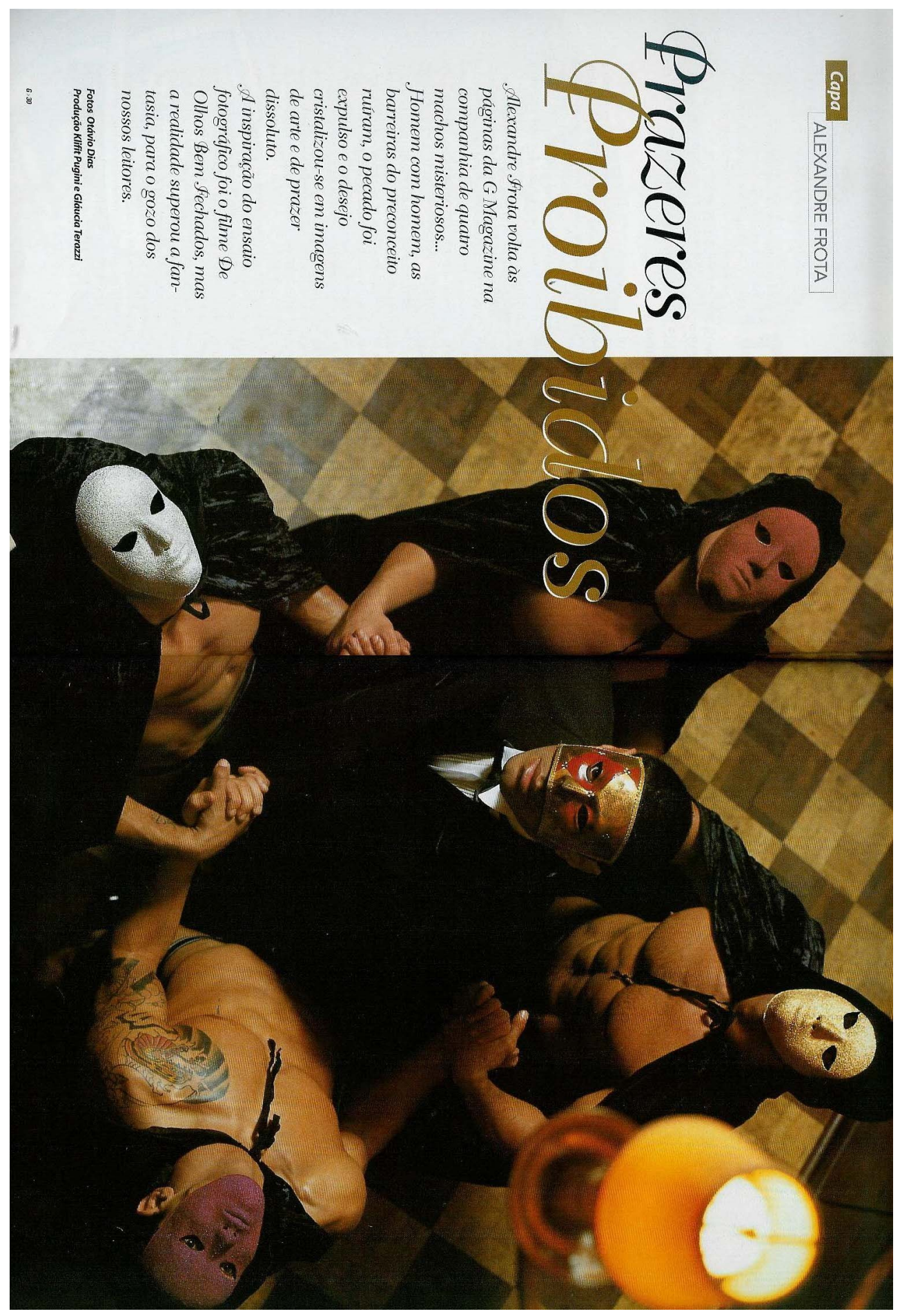

G 84 , p. $30-1$

Ensaio de capa intitulado Prazeres Proibidos, inspirado no filme 'De olhos bem fechados', de Stanley Kubrick: G Magazine visando à satisfação da demanda por prazeres barrados pela moral social, a contemplação midiática torna-se meio de manifestação de prazeres, não sendo imposto ao sujeito contemplador o ônus de tal manifestação. 


\section{Um público-alvo outsider.}

A demanda pela manifestação de prazeres socialmente proibidos é inerente ao ser humano. O suprimento desta demanda usualmente reflete em um comportamento barrado pela moral civilizante, de preceitos judaico-cristãos em nossa sociedade ocidental. No caso do grupo homossexual, a vivência da sua própria sexualidade os caracteriza como uma minoria em meio a uma cultura centrada no discurso da prática da heterossexualidade. Neste sentido, o segmento gay ocupa socialmente uma posição paralela à dos 'outsiders' analisados por Norbert Elias.

Mencionando o exemplo específico da comunidade britânica de Winston Parva - onde havia uma divisão entre as famílias que há algumas gerações povoavam o local e ditavam as regras do sistema (os estabelecidos) e os forasteiros que se chegavam à comunidade como novos habitantes (os outsiders) -, o autor analisa, sob a luz da dicotomia marxista opressores-oprimidos, uma série de relações estabelecidas socialmente naquele povoado, observáveis no cotidiano de qualquer comunidade ocidental dos dias de hoje.

Elias enfatiza a distância mantida entre os grupos em Winston Parva, pois "o grupo estabelecido atribuía a seus membros características humanas superiores; excluía todos os membros do outro grupo do contato social não profissional" (ELIAS 2000:20). A utilização de signos em determinados contextos 
servia de controle social por parte dos estabelecidos, estigmatizando e marginalizando os outsiders.

Para aplicação neste estudo, os estabelecidos (a maioria heterossexual de componentes da sociedade) impõem marcas aos outsiders (a minoria homossexual), utilizando-se de várias armas no exercício deste processo, dentre elas a linguagem. A criação e fixação, no imaginário social, de figuras e situações estereotipadas para representar o segmento homossexual perante a sociedade (algumas delas reforçadas pela própria G Magazine, como analisaremos adiante neste estudo) colaboram para a manutenção do diferencial entre os segmentos e, portanto, das posições distintas por eles ocupadas no sistema. A utilização destes estereótipos de forma pejorativa, especialmente quando o tom do discurso envolve o humor crítico não-construtivo e a freqüente exposição deste molde pela mídia ao público de massa, enraízam na sociedade o comportamento depreciativo para com o grupo homossexual.

Elias afirma que a capacidade de manipular a rede simbólica construída pelo discurso, com todas as suas representações, dá a quem a possuir o poder de legitimar uma ideologia perante o coletivo e, por conseqüência, ditar as regras de toda uma sociedade. Tal amplo poder de manipulação está usualmente a serviço do poder (dos) estabelecido(s). 
O uso da 'fofoca elogiosa' ou da 'fofoca depreciativa' por parte dos estabelecidos serve como meio de controle social, este ditado pelo discurso. "A estigmatização (...) associa-se a um tipo específico de fantasia coletiva criada pelo grupo estabelecido" (ibid., p. 35), fantasia esta inserida no imaginário social.

Tendo como referencial a estrutura social vigente, a $G$ Magazine configurase, desta forma, em mídia que ocupa uma posição duplamente desfavorecida no sistema: por veicular conteúdo socialmente barrado, um dos prazeres proibidos pelo código de conduta vigente, e por ser um veículo cujo público-alvo é constituído por indivíduos outsiders, componentes de uma parcela minoritária da sociedade, os homossexuais. 


\section{A busca pelo falo faltante.}

A necessidade intrínseca ao ser humano de sentir prazer em meio aos sofrimentos impostos pela existência impõe a este uma noção incômoda de incapacidade, de incompletude, de falta. Deste sentimento de falta, caracterizador de um sujeito partido, surge a busca por algo que faça o humano sentir-se completo, satisfazendo sua demanda por felicidade.

Em seus Escritos, Jacques Lacan elaborou sua teoria de que o sujeito, determinado pela linguagem, começa no lugar do Outro. O sujeito partido é, assim, caracterizado pela falta que seria suprida pelo Outro.

Este sujeito falto iniciará uma busca pela completude, busca esta instaurada pela linguagem. O que dá movimento à busca (ou, sentido à vida) é a procura pelo falo, que jamais será encontrado. Isso se configura na promessa da posse do falo faltante, que sublimaria a inteireza absoluta, a felicidade completa. Tendo em vista que o falo permanecerá faltante durante toda a vida do sujeito, a promessa jamais será cumprida para o sujeito, pois ninguém consegue obter o suprimento desta demanda, e isso mantém todos os humanos na permanente busca pela felicidade.

Compreender esta procura do sujeito pelo falo faltante é de extrema importância para se entender, segundo Lacan, como funciona a sexualidade. Em Os quatro conceitos fundamentais da Psicanálise, o teórico traça um paralelo 
antagônico deste sujeito partido na eterna busca pelo falo com a ameba, no que diz respeito à reprodução.

Segundo o autor, a reprodução não-sexuada da ameba concede a este ser uma condição de imortalidade: ela não necessita de um Outro para manter-se viva, para sentir-se completa, neste sentido apresentando uma característica de auto-suficiência. Tal imortalidade é subtraída do homem pelo fato de ele ser submetido ao ciclo da reprodução sexuada, necessitando do Outro para se reproduzir. A 'lâmina', que simbolicamente corta esta sensação de inteireza pela perda devida à passagem do homem pelo ciclo sexual, é a libido: esta força que leva o sujeito a procurar a satisfação da sua demanda pelo Outro.

Um dos papéis de $G$ Magazine é aguçar a necessidade de suprimento pela demanda causada pela falta do falo. Pretendendo ocupar um papel de detentora do falo, a revista disponibilizaria uma nuance da posse deste. Ao mesmo tempo que instiga a necessidade do suprimento por atiçar a libido dos leitores, a revista provê um vislumbre da posse do falo por meio da exibição dos prazeres proibidos.

Ana Maria Fadigas, jornalista e diretora responsável pela G Magazine, concedeu uma entrevista exclusiva especialmente para elaboração deste trabalho. Na ocasião, ela assumiu a dificuldade de trabalhar com o nu masculino no início da produção da revista. "Eu tinha medo do 'pinto', tive de criar coragem para olhar 
para ele", enfatizou, referindo-se especialmente à exibição do pênis, lugar-comum em todos os ensaios fotográficos da revista.

Por meio de uma - não rara - identificação errônea do pênis com o falo, Ana Maria, falando do papel da revista junto ao seu público-alvo, é enfática ao declarar: "O falo é de vocês!". O pênis, confundido com o falo faltante ao indivíduo, é colocado como uma dádiva da qual G Magazine ilusoriamente pretende-se possuidora e distribuidora entre seus leitores, atiçando a sua necessidade da busca pelo falo e suprindo sua demanda pela manifestação barrada de prazeres.

Como pretensa 'detentora do falo', a revista poderia oferecê-lo aos sujeitos partidos que por ele buscam, tornando-se disseminadora de prazeres proibidos, mecanismo por meio do qual leitores manifestariam seus desejos barrados socialmente. $G$ Magazine desencadearia nestes indivíduos o processo de manifestação de instintos sexuais moralmente reprováveis, reforçando a promessa da completude (nunca) atingida pela (impossível) posse do falo. Esta pseudocaracterística permite uma aproximação de G Magazine com a idéia de fetiche.

O termo 'fetiche' é empregado por diversas áreas. Emprestado da antropologia, nas ciências do comportamento ele designa um substituto mágico do falo faltante. Segundo David Zimerman, em seu Vocabulário contemporâneo de 
Psicanálise, o fetiche para Freud era "uma perversão sexual caracterizada pelo fato de uma parte do corpo (...) ou um objeto exterior (...) serem tomados como objetos exclusivos de uma excitação ou prática perversa de atos sexuais" (ZIMERMAN 2001:149).

Importante salientar que estes objetos são 'tomados como exclusivos de uma excitação', ou seja, cumprem o papel de atiçar a libido do sujeito que identifica nele um meio de reprimir a sua tensão. No processo de significação desencadeado pelo sujeito, os objetos tomam significações essencialmente sexuais e, uma vez atiçados pela libido, causam no organismo do indivíduo uma reação de excitação.

É pelo consumo do material, é pela admiração dos corpos nus nas seqüências fotográficas estampadas nas páginas da revista que o sujeito poderá manifestar seu prazer. O contato visual com a revista, respondendo momentaneamente à demanda da manifestação de prazer incitada pela libido, faz de $G$ Magazine um fetiche sexual para o sujeito que apresenta esta reação, por ser um objeto inanimado por meio do qual um fetichista manifesta seu prazer, supre sua demanda dotando-o de significação sexual. 


\section{Os três registros de Lacan.}

Segundo Jacques Lacan, a libido é a responsável pela ligação da pulsão sexual com o inconsciente, fazendo com que a sexualidade torne-se parte da vida psíquica do sujeito. Assim, para continuarmos analisando a $G$ Magazine, cujos ensaios fotográficos expressam conteúdo de teor sexual, faz-se necessário pesquisar como o autor estrutura o psiquismo humano.

A clínica lacaniana, herdeira de Freud, pressupõe um sujeito psicanalítico longe de ser uma entidade concatenada e central, como um homúnculo dentro da cabeça. O sujeito em Lacan é dividido entre um significante e outro, o que o torna eternamente partido. Este sujeito faltante seguirá a eterna busca pelo Outro (a grande alteridade), estruturando sua existência psíquica em três instâncias, quais são o Real, o Simbólico e o Imaginário.

O entendimento da tricotomia psíquica segundo Lacan é de suma importância para a comunicação, já que este processo, que obrigatoriamente se dá por meio da linguagem (eixo do registro simbólico), pressupõe o envolvimento de toda uma estrutura social (de ordem imaginária) pré-existente ao ato comunicativo, tendo em vista que a utilização dos signos passa por uma legitimação coletiva de suas representações, de ordem simbólica. 
Os corpos estampados nas páginas de $G$ Magazine estão legitimados coletivamente no imaginário social como linguagem que representa simbolicamente um perfil mais geralmente difundido para um segmento específico: o público gay.

Em 1953, Jacques Lacan faz uma conferência intitulada 'O Real, o Simbólico e o Imaginário', ocasião na qual o psicanalista apresentou publicamente as três instâncias do registro psíquico. Em recente artigo, Oscar Angel Cesarotto discorreu sobre a estrutura psíquica lacaniana. Para Cesarotto, "os três registros estão presentes desde o início do ensino de Lacan, até suas últimas intervenções", salientando a importância basilar desta estrutura (CESAROTTO 2005:26).

Começando pelas noções do Imaginário, esta instância desempenhou um papel essencial na constituição do pensamento de Lacan, o que levou alguns a definirem toda sua obra pela maneira como o francês se posicionava perante 0 Imaginário. No seu Seminário XXII (RSI, de 1974-5), Lacan afasta qualquer idéia de fases, acentuando a natureza combinatória da estrutura por ele apresentada.

No seu artigo, Cesarotto explica que

"o imaginário inclui duas acepções. Por um lado, quer dizer falso e, por este viés, aponta à ilusão de autonomia da consciência. Por outro lado, tem a ver 
diretamente com as representações e as imagens, as matérias-primas das identificações" (Idem, p. 25).

A instância do Imaginário acaba sendo o lugar do Eu por excelência, com seus efeitos de ilusão e engodo. O Eu é uma construção imaginária. Isto o caracteriza em sua precariedade, num contínuo processo de identificações parciais (a construção do Eu; a antecipação de uma forma global de corpo pela captação da imagem do outro, matriz imaginária do Eu).

Na teoria freudiana, o Imaginário lacaniano corresponde ao plano do narcisismo. É o momento fundamental da cristalização da imagem do corpo, instalando a matriz do ego no psiquismo. Fora disso, o humano somente existe porque fala. Sobre este aspecto, Lucia Santaella enfatiza que

"o imaginário é basicamente o registro psíquico correspondente ao ego (ao eu) do sujeito, cujo investimento libidinal foi denominado por Freud de Narcisismo. O eu é como Narciso: ama a si mesmo, ama a imagem de si mesmo... que ele vê no outro. Essa imagem que ele projetou no outro e no mundo é a fonte do amor, da paixão, do desejo de reconhecimento, mas também da agressividade e da competição" (SANTAELLA 1999:83).

Lacan constituiu a idéia de que o fato de o sujeito identificar-se com a imagem especular de um outro é "constitutiva do eu ( $m o l)$ no homem, e que o 
desenvolvimento do ser humano está escondido por identificações ideais" (Idem, p. 84). Segundo Santaella, este processo de identificações se chama 'alienação imaginária': é um desenvolvimento no qual o imaginário está inscrito, e não um simples desenvolvimento fisiológico.

O reconhecimento da identidade do eu dá-se através de uma imagem especular em um jogo paradoxal que oscila entre eu e o outro (o bebê que reconhece sua imagem no espelho ao mesmo tempo vê a si mesmo, mas vê também um outro). Para o francês Jacques Aumont (1992),

"en el sentido corriente de la palabra, lo imaginario es el patrimonio de la imaginación, entendida como facultad creativa, productora de imágenes interiores eventualmente exteriorizadas. Prácticamente, es el sinónimo de 'ficticio', de 'inventado', y opuesto a lo real (incluso, as veces, a lo realista). En este sentido banal, la imagen representativa hace ver un mundo imaginario, una diégesis" (AUMONT 1992:125).

O Imaginário é visão de mundo, é construção de uma leitura sobre o mundo por meio de imagens mentais que, inclusive, são determinantes para o processo de identidade do sujeito. Tendo a imagem do corpo como modelo, o Imaginário corresponde a sínteses ilusórias, à criação de totalidades perfeitas, mantendo intocadas todas as diferenças reais. 
Ao mesmo tempo senhor e servo do Imaginário, "o ego se projeta nas imagens em que se espelha: imaginário da natureza, do corpo, das relações sociais", salienta Santaella (1999). Enfim, o registro Imaginário seria

"uma mônada [na filosofia leibnizianista, átomo inextenso, imaterial, indivisível e eterno, com atividade espiritual] que se alimenta da miragem do outro, uma miragem na iminência da dissipação e da perda. Ser eu, sendo, ao mesmo tempo, o outro, é idílico mas também mortífero, pois um dos pólos dessa pretensa unidade está sempre à beira do desaparecimento" (Idem).

Como imagem, o Imaginário recobre a totalidade do mundo, isto é, duplicao, funcionando como uma espécie de filtro. Se o Imaginário fosse azul, por exemplo, o mundo seria totalmente azul. Deste ponto de vista, qualquer visão da realidade é puramente imaginária.

É neste Imaginário que a fotografia, uma imagem sintética, será representada, sendo duplicada de acordo com o filtro e criando uma interpretação idealizada, uma visão subjetiva da realidade. Sob a atuação da libido, o corpo fotografado e publicado por $G$ Magazine é visualmente consumido pelo sujeito que o representa no Imaginário de forma ilusória. Este sujeito identifica-se com a interpretação idealizada da imagem. O ego, na busca por si mesmo, por sua 
identidade, acredita encontrar-se no espelho das criaturas para se perder naquilo que ele não é.

A leitura subjetiva da realidade no Imaginário cria as ilusórias totalidades perfeitas, como a interpretação do corpo fotografado. De posse desta ilusão, o sujeito faltante sente-se momentaneamente de posse do falo que lhe conferiria completude, processo que apenas ocorre na instância do Imaginário.

Visto de fora, temos um mundo volátil e volúvel; visto do olhar daquele que está preso no seu imaginário, temos uma totalidade rotunda e fechada sobre si própria. Nesta última perspectiva, cada imagem torna-se única, e constituindo uma totalidade, impede qualquer ligação real aos outros sujeitos e ao próprio mundo.

Segundo Lacan, cabe à instância do Simbólico a tarefa de abalar este caráter delirante, por ser o princípio da exterioridade (que ele metaforiza como significante, estruturado em torno da lei, constituindo um mundo ordenado e regrado, estruturando a realidade de maneira objetiva).

Mencionando este outro elemento da tricotomia psíquica lacaniana, Cesarotto declara que

"o registro do simbólico tem, na linguagem, sua expressão mais concreta, regendo o sujeito do inconsciente. Ela é a causa e o efeito da cultura, 
onde a lei da palavra interdita o incesto e nos torna completamente diferentes dos animais" (CESAROTTO 2005:25).

Em Lacan, o Simbólico indica um retorno a Freud à luz de questões retiradas das interpretações de estudos lingüísticos de Ferdinand de Saussure e antropológicos de Claude Lévi-Strauss. Nos trabalhos freudianos, a importância deste registro pode ser notada nos textos que ilustram o funcionamento do inconsciente, como nas reflexões acerca do Complexo de Édipo, já que a 'função do pai' está ligada a essa instância.

Lucia Santaella explica que

"o registro simbólico é o lugar do código fundamental da linguagem. Ele é lei, estrutura regulada sem a qual não haveria cultura. Lacan chama isso de grande Outro. O Outro, grafado com maiúscula, foi adotado para mostrar que a relação entre o sujeito e o grande Outro é diferente da relação com o outro recíproco e simétrico ao eu imaginário" (SANTAELLA 1999:84).

Assim, o grande Outro, em todos os sentidos, é lei, mediação, estrutura regulada e reguladora que prescreve o sujeito, impondo-lhe a falta, barreira representada pela linguagem. O sujeito existe por intermédio da linguagem, uma existência que tem de ser comprovada simbolicamente pelo uso da linguagem. 0 
Simbólico parece corresponder à fixação histórica do especular: tudo devém imagem através dele.

O Simbólico confunde-se com a matriciação do existente, como ocorre, por exemplo, pela linguagem, que pode ser descrita como uma matriz. O Simbólico tenta regular, dar 'ordem' ao caos, tentando posicionar todo e cada signo em um determinado lugar na rede de significação.

O Simbólico é demonstrado comumente pela linguagem. Formada por signos, a linguagem tem o papel de codificar conceitos de referenciais em um sistema organizado, concedendo a cada signo uma posição a ocupar e/ou uma função a desempenhar em uma dada realidade. Por isso, é a partir desta instância que as sociedades constroem suas culturas, representando idéias por intermédio de signos e posicionando-os numa rede complexa e organizada que tenta ordenar todas as coisas, atribuindo a estas seus respectivos valores.

É esta instância psíquica a responsável por posicionar o conteúdo das fotografias publicadas por $G$ Magazine em um local específico da rede de significantes. Este posicionamento simbólico concede às imagens ali representadas valores que atuarão no Imaginário do sujeito-leitor, que delas fará uma interpretação ilusória. A atuação da libido no sujeito será determinante para a reação que este apresentará quando exposto à imagem, tendo em vista o teor 
sexual do conteúdo das fotografias em questão. A fotografia, como linguagem, é de natureza simbólica e, de acordo com a leitura ilusória do Imaginário do leitor, poderá suprir a demanda deste pela demonstração de prazer.

Se o Real é a totalidade intotalizável, e o Imaginário é a totalidade ilusória e da ilusão, o Simbólico é o espaço onde este afrontamento ocorre, o espaço de mediação. Ele é da ordem da totalidade, que captura através do simulacro, que se desconhece enquanto tal. O Simbólico é a mediação estruturada entre os devaneios do Imaginário e a espontaneidade selvagem do Real.

Segundo Lacan, o Real é o impossível, o acidental, a interpelação permanente. Dado o seu caráter perturbador, tanto o Imaginário como o Simbólico são formas de evitá-lo, seja por falsa reconciliação imaginária, ou por cristalização numa rede institucional simbólica.

Fechando o ciclo tricotômico de Lacan, Cesarotto explica a instância do Real que, segundo este,

"como terceira dimensão, é sempre aludido pela negativa: seria aquilo que, carecendo de sentido, não pode ser simbolizado, nem integrado imaginariamente. Aquém ou além de qualquer limite, seria incontrolável e fora de cogitação" (CESAROTTO 2005:25). 
Pertence à instância do Real tudo aquilo que não é representável, que não se exprime por intermédio de qualquer signo. O Real é o impossível, aquilo que a linguagem deixa escapar (não suporta) na representação.

Lucia Santaella descreve que

"o registro psíquico do real não deve ser confundido com a noção corrente de realidade. Para Lacan, 0 real é aquilo que sobra como resto do imaginário e que o simbólico é incapaz de capturar. O real é o impossível, aquilo que não pode ser simbolizado e que permanece impenetrável ao sujeito do desejo para quem a realidade tem natureza fantasmática. Diante do real, o imaginário tergiversa e o simbólico tropeça. Real é aquilo que falta na ordem simbólica, os restos que não podem ser eliminados em toda articulação do significante, aquilo que só pode ser aproximado, jamais capturado" (SANTAELLA 1999:85).

Tudo depende, portanto, da instância do Real, que é sempre um limite da simbolização, da representação. Nota-se a sua presença pelo fato de algo falhar no Simbólico, enquanto que no Imaginário tudo funciona, menos a vida, que é lesada brutalmente. O Real é composto por tudo aquilo de que o Imaginário tenta esquivar-se, tenta procurar subterfúgios à fuga do seu idealismo, ao mesmo tempo em que é composto também por tudo aquilo de que o Simbólico não dá 
conta de representar, que foge à possibilidade de uma simbolização por intermédio da linguagem.

O Real é a realidade psíquica, que engloba as fantasias do sujeito. É a base pulsional do 'id' freudiano, sobre a qual se organiza todo o aparelho psíquico; a força que foge da idealização imaginária, bem como da ordenação simbólica. 0 Real é a categoria da pulsão sexual, que leva o sujeito a possuir uma demanda a ser suprida. Todos os instintos primitivos que o sujeito deve manter latentes no meio civilizado são desta ordem. O estado de tensão que leva o indivíduo, por exemplo, a contemplar as seqüências fotográficas de $G$ Magazine reina nesta instância.

Cada um dos elementos do psiquismo lacaniano faz circular os outros dois, não podendo reduzir nenhum deles. É isso mesmo que explica o papel positivo do Imaginário nas teorias vulgares, pois constitui uma falha, ou um buraco, no seio do Simbólico. Enquanto campo do desdobramento narcísico, das imagens, fantasmas e semelhanças, o Simbólico forma um horizonte de espelhamento do Real.

Os três registros lacanianos interferem diretamente no processo de representação de qualquer signo, pois a posição deste na rede simbólica e sua leitura imaginária dependem diretamente do funcionamento da estrutura psíquica 
do sujeito. Da pulsão sexual, passando pelo desejo até a manifestação dos prazeres proibidos, o caminho percorrido passa pelas três instâncias de Lacan.

Mais adiante, um paralelo entre os três registros psicanalíticos lacanianos e as três categorias semióticas peirceanas, sugerido por Lucia Santaella, permitirão uma aproximação da linguagem fotográfica de $G$ Magazine do processo psíquico de interpretação de signos. Este paralelo poderá nos auxiliar na compreensão de como elementos intrínsecos ao sujeito, neste caso a sexualidade do público-alvo do veículo, podem influenciar na interpretação de uma linguagem, bem como o discurso por ela representado. 


\section{A instituição imaginária da sociedade.}

Tratando-se de discurso na mídia, a importância de se conhecer como funciona a estrutura coletiva do Imaginário no social é de extremo valor, tendo em vista a necessidade da manipulação desta esfera para reforço de uma ideologia.

Cornelius Castoriadis, em sua obra intitulada $A$ instituição imaginária da sociedade, discorre sobre as evidências de como os sistemas de organização humana - de natureza social, cultural ou religiosa - somente podem ser entendidos a partir da relação entre a ordem simbólica e o Imaginário. 0 autor destaca a fundamental importância do Imaginário na compreensão dos fenômenos sociais, mostrando como tentativas de entendimento da realidade empreendidas por diversas correntes filosóficas de pensamento não se sustentaram, pois todas, de alguma forma, desprezaram o "componente imaginário de todo símbolo e de todo simbolismo em qualquer nível que se situem" (CASTORIADIS 1986:154).

Castoriadis explica que o Simbólico e o Imaginário têm profundas relações entre si, já que "o imaginário deve utilizar o simbólico não apenas para exprimirse, mas para 'existir', para passar de virtual a qualquer outra coisa". Inversamente, "o simbólico também pressupõe a capacidade imaginária, para ver em uma coisa o que ela não é, de vê-la diferente do que é" (idem). 
O autor salienta que é no Imaginário que uma sociedade procura o complemento necessário para sua ordem, uma vez que no núcleo deste Imaginário é que se encontra um sentido que não é ditado por fatores reais porque, antes disso, é esse Imaginário que confere a esses fatores reais tal importância e tal lugar no universo, ou seja, suas representações. Estes conjuntos de representações que vão se articulando - como se fossem uma rede - têm como efeito a construção da realidade em que vivemos, formando uma rede simbólica e, ao mesmo tempo, uma ordem imaginária. Tal ordem rege os lugares representados pelas coisas na sociedade humana; tal ordem rege o sentido de significação dos signos em uso, estabelecendo hierarquias dentro da linguagem.

Assim, conforme o próprio Castoriadis, "o imaginário da sociedade (...) determina a escolha [do signo] e as conexões das redes simbólicas [por ele estabelecidas]" (ibid, p. 175). O signo em seu uso social ganha vida quando corresponde, no Imaginário da sociedade, à representação de um lugar na rede simbólica ocupado por um 'nó', ou referencial. O indivíduo interage quando o signo utilizado no ato comunicativo representa para ele alguma coisa dentro do seu universo de conhecimento, coisa essa socialmente posicionada, coletivamente passível de significação.

Nota-se, a partir do explanado por Castoriadis, o profundo diálogo estabelecido entre os registros do Simbólico e do Imaginário para que uma 
mensagem seja transmitida. Desta forma, a linguagem estabelece uma rede simbólica, tecida sobre uma base imaginária, para transmitir uma mensagem. Os signos utilizados como portadores simbólicos de significado tecem um discurso que encontra espelhamento em uma ordem imaginária, que concede a importância que as representações simbólicas estabelecidas pelos signos terão.

Os corpos representados nas fotografias publicadas por $G$ Magazine são signos - e os chamaremos neste texto de 'corpos-signos', por reunirem facetas dos registros imaginário [a imagem do corpo] e simbólico [a representação] na transmissão da mensagem. Estes corpos-signos correspondem, no Imaginário do público-alvo da revista, a um lugar na rede simbólica dotado de significação de cunho sexual. É principalmente este aspecto sexual que incita a libido deste fragmento do mosaico social, que busca o suprimento de uma demanda, a ilusória posse momentânea do falo faltante.

O sujeito-leitor de $G$ Magazine entra em uma rede simbólica baseada nos corpos-signos que tecem o discurso da revista, representada naquele corpo apresentado pela fotografia. Este signo da instância do Simbólico corresponde, no Imaginário deste sujeito, ao suprimento momentâneo de uma demanda: a pulsão sexual, da ordem do Real, incitada pela libido que reagiu à ação da representação sígnica no Imaginário. 
Para entendermos melhor as noções de signo, da fotografia como meio de mensagem e do direcionamento em que as mensagens em geral estão embebidas, a próxima parte deste trabalho focará os aspectos do estudo da linguagem, centrando-se mais na linguagem da imagem e, em especial, da fotografia. 


\section{CAPÍTULO III}

DAS IMAGENS 


\section{A estrutura do discurso.}

As seqüências de fotografias com homens posando nus são marca registrada de $G$ Magazine, que sempre exibe como manchete de capa uma chamada acompanhada de uma foto do protagonista do ensaio principal. A fotografia da capa não é pornográfica; a única exceção a esta regra continha uma tarja sobre o pênis do modelo, que poderia ser destacada pelo leitor. O ensaio de capa configura-se na parte mais importante de toda a edição da revista, é o foco central de apelo junto ao público-alvo.

A revista possui como carro-chefe a publicação de material imagético com teor sexual visando à incitação de prazeres. Partindo das bases acerca da sexualidade lançadas no capítulo anterior, o trabalho centra-se a seguir no estudo da linguagem utilizada por $G$ Magazine, na forma como a revista apresenta os corpos-signos ao seu leitor.

O signo - elemento de representação - em seu uso social ganha vida quando corresponde à representação de um lugar na rede simbólica, ocupado por um 'nó'. Em suma, o signo cumpre seu papel a partir do momento em que representa algo para um interlocutor. 0 indivíduo interage quando o signo utilizado no ato comunicativo representa para ele alguma coisa dentro do seu universo de conhecimento, coisa essa socialmente posicionada, coletivamente passível de significação. 
A construção desta rede simbólica no cotidiano será reforçada pelo uso dos signos com um direcionamento específico, ou seja, no discurso. Neste estudo, os signos posicionados são as seqüências de fotografias, e o ideário que elas constroem no imaginário social decorre do discurso apresentado por G Magazine.

Para melhor entendimento do ponto, o Dicionário de Semiótica, de autoria de Joseph Courtés e Julien Greimas, tece noções acerca do conceito de discurso, propondo uma definição bastante ampla e complexa, dividida basicamente em onze tópicos. Segundo os autores, o discurso é (1) sinônimo de enunciado: como um texto, produto real de um emissor; (2) dotado de procedimentos e normas para sua construção: o resultado do encadeamento de frases; (3) dispositivo articulado em diferentes níveis narrativos: como modalidades do enunciado; (4) resultado da competência do enunciador: dependente da competência lingüística de quem emite o código; (5) língua em ato: restrito às condições necessárias para a comunicação; (6) articulações significantes: nascendo na enunciação, dado pelas colocações em discurso; (7) comunicação: como um discurso instrumental; (8) conteúdos investidos na enunciação: a ideologia; (9) socialmente produzidos: literatura médica, política, econômica, lírica etc; (10) tipologia conotativa: trabalhando o jogo entre formas e conteúdo; e finalmente (11) processos semióticos: que põem na enunciação o lugar de geração do discurso. 
De forma geral, as noções de discurso explanadas por Courtés e Greimas iniciam-se no campo do enunciado, ou como produto final social (texto) para, em seguida, desdobrarem-se da definição inicial em uma série de outras definições derivadas umas das outras, até chegarem a tratar da instância da enunciação enquanto o lugar onde o discurso é gerado. Este estudo se centrará no discurso partindo dos conteúdos investidos na enunciação, e socialmente produzidos, tendo em vista se tratar de uma literatura de público-alvo bastante específico.

A G Magazine, impulsionada por toda uma tendência de mercado, consolida-se como mídia impressa voltada para o fragmento social composto pelo grupo de indivíduos homossexuais masculinos brasileiros. Para consolidar esta posição, a revista mantém um discurso imagético repleto de signos de ordem simbólica (os corpos-signos), profundamente arraigados em interpretações produzidas no imaginário social, vinculados à pulsão sexual e à libido. Os mecanismos envolvidos do processo de sexualidade nos auxiliarão a compreender o funcionamento da interpretação desta linguagem dos corpos-signos utilizada pela revista.

A capacidade de direcionar a rede simbólica construída pelo discurso, com todas as suas representações, permite o surgimento/fortalecimento de aspectos do imaginário social capazes de persuadir um coletivo e, por conseqüência, ditar os parâmetros a serem seguidos para a criação de uma identidade no mosaico social. 
Dentre seus objetivos, este estudo pretende identificar como a revista $G$ Magazine constrói seu discurso utilizando como linguagem a fotografia do nu masculino para o seu público-alvo.

A utilização do discurso como mantenedor do poder no sistema não é um tema novo no meio acadêmico. Parte da obra produzida por Michel Foucault, um dos maiores filósofos e historiadores ocidentais do século $X X$, dedica-se a este foco, como também ao discurso específico da sexualidade.

No início da década de 1950, Foucault segue o famoso Seminário de Jacques Lacan. Começa, então, a fase mais produtiva, no sentido acadêmico, na vida do filósofo, fase esta que dura cerca de 30 anos. Em 1971, Foucault assume a cadeira de Jean Hyppolite na disciplina "História dos Sistemas de Pensamento". A aula inaugural de Foucault nessa cadeira foi a famosa "A Ordem do discurso", que veio a se tornar livro, obra primordial para o estudo do discurso na sociedade contemporânea.

Neste meio tempo, Foucault publica Doença Mental e Psicologia (1954), mas foi com História da Loucura (1961), sua tese de doutorado na Sorbone, que o francês firmou-se como filósofo. Neste livro, o autor analisa as todas as práticas sociais impostas pela sociedade ocidental dos séculos XVII e XVIII que levaram à exclusão do convívio daqueles que chamavam de "desprovidos de razão". 
Foucault preferia ser chamado de "arqueólogo", pois procurava sempre analisar o que mais profundo existe numa cultura - arqueólogo do silêncio imposto ao louco, da visão médica (Nascimento da Clínica, 1963), das ciências humanas (As Palavras e as Coisas, 1966), do saber em geral (A Arqueologia do Saber, 1969), escrutinando as bases argumentativas que cada uma dessas visões utilizava para legitimar suas leituras do mundo.

Vigiar e Punir (1975) é um amplo estudo sobre as atuais formas de disciplina impostas pela sociedade. Foucault resumia a estrutura prisional existente a "uma técnica de produção de corpos dóceis". O conceito da prisão teria por objetivo o marginal do proletariado; as ilegalidades da classe dominada eram confinadas, aprisionadas. Foucault analisou os processos disciplinares empregados nas prisões, considerando-os exemplos da imposição, às pessoas, de padrões "normais" de conduta estabelecida pelas ciências sociais.

A partir desse trabalho, explicitou-se a noção de que as formas de pensamento são também relações de poder, que implicam a coerção e imposição. Foucault assume um leve relance de filosofia marxista na linguagem. Assim, é possível lutar contra a dominação representada por certos padrões de pensamento e comportamento, mas torna-se impossível escapar a todas e quaisquer relações de poder. 
Michel Foucault, infelizmente, deixou inacabado seu mais ambicioso projeto, A História da Sexualidade, por meio da qual o autor pretendia mostrar como a sociedade ocidental faz do sexo um instrumento de poder, seja por meio da repressão, seja da expressão. O primeiro dos seis volumes anunciados foi publicado em 1976 sob o título $A$ vontade de saber, e despertou duras críticas. Este volume é pedra angular para o presente estudo. Em 1984, pouco antes de morrer, Foucault publicou outros dois volumes, rompendo um silêncio de oito anos: $O$ uso dos prazeres (tratando da sexualidade na Grécia Antiga) e $O$ cuidado de si (cujo foco é a Roma Antiga).

Ao longo de sua obra, Michel Foucault apresenta a manipulação do discurso como poderosa ferramenta para a legitimação da estrutura do poder. O francês dedica a trilogia História da Sexualidade para delinear a rede simbólica de significantes ligados à sexualidade como ferramenta largamente utilizada com esta finalidade: a manutenção do poder no sistema.

G Magazine utiliza-se de uma rede simbólica profundamente ligada à sexualidade para estruturar sobre esta o seu discurso. O corpo-signo nu, matériaprima dos ensaios fotográficos publicados pela revista, é a linguagem adotada pelo veículo para passar sua mensagem ao seu público-alvo. O discurso do sexo como atividade é, portanto, uma constante na revista. A partir desta constatação, faz-se 
mister uma abordagem mais específica do sexo em discurso, norteado com base nas análises extraídas dos estudos 'arqueológicos' de Michel Foucault acerca do assunto. 


\section{O sexo como discurso.}

O controle sobre a comunicação pode mover povos inteiros em prol de uma filosofia, seja este poder colocado pela expressão (como na Alemanha da década de 1930) ou pela repressão (como nos regimes militares na América Latina entre as décadas de 1950 e 1980). Conforme vimos, este ponto foi um dos cernes da produção científica do filósofo e historiador francês Michel Foucault: a utilização do discurso para a manutenção do poder em suas posições estabelecidas.

Em sua trilogia História da Sexualidade nos é mostrada a visão foucaultiana sobre como o discurso do sexo tem servido de instrumento de manutenção do poder, seja pela repressão ou pela expressão excessiva de signos ligados à sexualidade humana.

Ao longo da História, de acordo com Foucault, o sexo vem sendo utilizado como discurso por aqueles que detêm o poder de decisão. Repetidamente estes se valem da rede simbólica constituída sobre a sexualidade para tramarem uma forma de manterem sua posição no sistema, uma forma de legitimar o lugar que ocupam e não modificar funções na estrutura do sistema, preservando o funcionamento do eixo.

Foucault, ao longo de sua famosa obra História da Sexualidade, analisou como o imaginário da sociedade é manipulado com o objetivo do estabelecimento 
de um jogo de manutenção de poder. Abrangendo desde o apogeu dos impérios grego e romano até - e especialmente - o mundo ocidental pós-Iluminismo, o autor analisa como este imaginário posiciona signos na rede simbólica, dando vida a estes signos em uso, ponto também trabalhado pelo mesmo autor em $A$ ordem do discurso.

De acordo com Foucault, tal jogo, por sua vez, é instituído pelo discurso, e o autor vai utilizar como exemplo as características discursivas que envolveram a sexualidade, especialmente nos últimos três séculos, para comprovar sua teoria, partindo de uma perspectiva repressora quanto ao assunto na modernidade a uma expressão exacerbada na contemporaneidade. A perspectiva foucaultiana quanto à manipulação por meio do discurso do sexo é importante norteador deste trabalho, tendo em vista a linguagem utilizada pela G Magazine.

Na sua obra sobre a história do sexo, Foucault começa abordando a repressão burguesa ao longo do século XVII com relação à sexualidade, tendo o pudor como norteador do sistema de exclusão. Nesta época, o discurso sobre o sexo era primeiramente incitado para, logo após, ser reprimido. A noção do prazer aliada ao pecado auxiliava muito neste processo: o sexo é bom, mas causa sobre aqueles que o utilizam de forma errada a imputação do castigo divino. 
A partir do século XVIII, há uma 'explosão discursiva' em torno do tema. 0 sexo em discurso passa a ser mecanismo de poder para o fortalecimento da potência interna do Estado, sendo neste momento o pudor substituído pelo 'sistema de utilidade'. Uma nação forte tem uma população numerosa e, portanto, mão-de-obra para seu desenvolvimento, sendo o sexo ferramenta biológica necessária para implantação/manutenção desta força.

No século XIX há o que o autor chama de a 'implantação perversa', e a proliferação do discurso sobre a sexualidade dá-se no eixo da 'lei da aliança' e da 'ordem do desejo'. O primeiro eixo visa ao casamento e à reprodução, indo ao encontro dos valores burgueses de família, apoiados pela moral religiosa judaicocristã vigente na sociedade ocidental. O segundo visa ao prazer vulgar, que Foucault vai chamar de 'perversão', com o surgimento dos primeiros indicadores, sob o ponto de vista científico, de comportamentos sexuais que visavam ao prazer, não tendo como finalidade específica a reprodução biológica.

Assim, as facetas da sexualidade que fugissem ao objetivo da procriação deixariam de ser encaradas como pecados contra a natureza e, gradativamente, ocupam o status de anormalidades patológicas (dentre elas a homossexualidade, que a Organização Mundial da Saúde declarou oficialmente não se tratar de uma doença apenas em meados da década de 1980). A Igreja cede lugar à Medicina, e o poder passa a ser exercido pela interdição. Quem praticasse quaisquer atos 
sexuais que não tivessem por finalidade a reprodução - caso dos atos homossexuais, por exemplo -, era preso, como ocorreu com o escritor inglês Oscar Wilde na década de 1890.

Já no século XX, Michel Foucault menciona a expressão exacerbada da sexualidade como um dispositivo de saturação. Cria-se, a partir deste quadro, o jogo paralelo entre poderes e prazeres, como um mecanismo de dupla incitação. Há posições no sistema para as quais determinados comportamentos sexuais são acessíveis, possíveis, passíveis de ocorrer.

Legitima-se, com este discurso, um jogo que estabelece um traçado paralelo entre a posição que o indivíduo ocupa no sistema (e o poder que a ele se concede por ocupar tal posição) e a sexualidade que o indivíduo poderá exercer (os prazeres a ele outorgados). A determinadas pessoas são barradas certas formas de demonstração de prazer, pois a posição por elas ocupada no sistema social não as concede, dentro do imaginário social, ocuparem tal posição.

Este início do século XXI parece dar continuidade à expressão da sexualidade, mantendo também a dualidade estabelecida entre poderes e prazeres, ambas indicadas por Michel Foucault. $\mathrm{O}$ expressivo aumento da veiculação de material de incitação erótico-pornográfica, tanto em mídia impressa como televisiva ou cibernética, comprovam tal leitura. 
Os periódicos cujo principal atrativo é o nu proliferam, bem como cenas de nudez (parcial ou total) ou atos sexuais - mais ou menos explícitos - na teledramaturgia em horário nobre na televisão aberta no Brasil, em apresentações de dançarinos com movimentos libidinosos em programas de auditório, enfim, um sem número de exemplos. A representação - em tons mais ou menos explícitos do sexo é um verdadeiro bombardeio nos meios de comunicação.

Neste ínterim, a $G$ Magazine consolida-se como veículo na produção brasileira de material que trabalha com o nu e, portanto, com questões diretamente ligadas a um discurso da sexualidade. A existência do veículo ao longo de quase 10 anos, hoje já com mais de 100 edições publicadas, comprova a representatividade do produto junto a seu público em um ramo marcado pela efemeridade e inconstância dos veículos, especialmente os impressos em um país de pouca tradição de leitura.

A revista utilizar-se-á da fotografia com conteúdo sexual como teia significante sobre a qual ela construirá o seu discurso. Desta forma, torna-se flagrante o uso do sexo em discurso, por parte de G Magazine, para expor sua visão de mundo ao seu público-alvo. 
Esta publicação configura-se em exemplo da explosão discursiva do sexo mencionada por Michel Foucault na sociedade contemporânea. Por intermédio das seqüências dos ensaios fotográficos, carros-chefe das suas edições, a revista constrói sua rede simbólica de significantes e transmite aos leitores uma mensagem utilizando a linguagem de grande apelo e, portanto, vasto consumo junto ao público adulto: o sexo.

O discurso do sexo utilizado por $G$ Magazine constrói-se sobre uma rede de significantes imagéticos: os ensaios fotográficos. Uma abordagem de como se estrutura esta linguagem peculiar, de como funcionam mecanismos de representação por intermédio da imagem estática captada e cristalizada na fotografia é passo importante para a continuidade deste estudo. 


\section{A linguagem fotográfica.}

A fotografia, quando utilizada na imprensa, torna-se preciosa ferramenta de persuasão para a criação ou fortalecimento de mitos e estereótipos junto a um meio social. Tal poder Ihe é conferido, dentre outras características, por intermédio do apelo que a fotografia tem, desde os seus primórdios, de ligação com a realidade, como um espelho do que é real (DUBOIS 2004:27), associação esta que persiste muito ainda nos dias de hoje, de documento de teor factual. Susan Sontag esclarece que a fotografia hoje "é, sobretudo, rito social, defesa contra a ansiedade e instrumento de poder" (SONTAG 1981:132; grifo meu).

Esta fotografia, possuidora de aspectos tão peculiares, será a linguagem utilizada por $G$ Magazine para passar sua mensagem a seu público-alvo. Em suas páginas principais, a revista publica representações de corpos-signos, que por sua vez se configuram em construtores de um discurso específico.

Philippe Dubois, em $O$ ato fotográfico, por vários momentos aproxima a consideração das imagens fotográficas aos três níveis de significação explanados na teoria semiótica de Charles Sanders Peirce (DUBOIS 2004:45). Para Peirce, a decodificação de signos passa por três estágios, ou categorias do pensamento fenomenológico: primeiridade (índice - signo que denota o referente baseado na conexão física entre ambos), secundidade (ícone - signo que denota o referente simplesmente em virtude das características que ele possui, quer esse referente 
exista realmente, quer não) e terceiridade (símbolo - signo que denota seu referente em virtude de uma lei, associação de idéias, convenção) (SANTAELLA 2003b).

O leitor vai posicionar aquele corpo-signo na teia simbólica de significantes, dando luz a uma leitura subjetiva - imaginária - de uma realidade desencadeada pela exposição à fotografia: a existência daquela imagem. As 'imagens mentais preconcebidas' acerca da sexualidade, mencionadas por Kossoy (1999), é que farão com que o sujeito que interage com a fotografia a posicione na teia simbólica e, conseqüentemente, imponha a ela um valor imaginário.

Se a fotografia, como índice, é signo por conexão física com o referencial, a interpretação de uma imagem fotográfica carrega fortemente o sentido de significação do que nela está cristalizado como imagem para o espectador. 0 mesmo Dubois esclarece que

"quando determinada fotografia oferece a nossos olhos interrogadores a visão de determinada personagem, por exemplo, um homem de uniforme ao lado de um cavalo arreado, só temos certeza de uma coisa: esse homem, esse cavalo, esse arreio existiram, estiveram efetivamente ali, um dia, naquela posição. Mas é tudo o que a foto nos diz. Nada sabemos sobre a significação (geral ou particular) que se deve atribuir a essa existência" (DUBOIS 2004:84). 
Assim, a fotografia é um indício (estabelecido pela conexão física) da existência dos elementos nela porventura cristalizados, mas que sozinha não confere significação a tais elementos, deixando-os sem qualquer tipo de explicação, interpretação ou comentário. Cabe ao espectador preencher estas lacunas que o índice fotográfico deixa abertas: cabe a quem observa a imagem fotográfica fazer uma interpretação dela, baseada em valores de ordem subjetiva, individuais ou coletivamente legitimados, impressões mentais sobre o referencial ali retratado que fogem ao enquadramento daquela imagem.

Porém, quando contextualizada, a fotografia - como qualquer outro signo ganha direcionamentos de sentido de acordo com o discurso ao qual ela serve como linguagem. $\mathrm{O}$ fato de um texto qualquer - verbal ou imagético - estar inserido na revista já direciona seu sentido. Uma única fotografia em G Magazine, na verdade, é uma fatia de uma seqüência que, por sua vez, constrói uma lógica de sentido: o discurso da revista. Ou seja, cada fotografia encontra um encaixe na seqüência do ensaio, embebendo-se do direcionamento na construção desta seqüência, bem como da revista. Como um elo em uma corrente, o signo fotográfico em $G$ Magazine está seqüencialmente ligado ao anterior como sucessor, bem como ao seguinte como antecessor, construindo uma série coesa, ocupando seu lugar e sua função no todo do sentido, quer dizer, no discurso do veículo. 
Assim, é prudente examinar fotografias na $G$ Magazine tendo em mente que cada uma destas imagens é, individualmente, apenas uma fatia de um discurso. A observância da repetição de certos aspectos específicos destas imagens nos auxiliará a identificar o caminho percorrido pela estruturação do discurso por parte da revista, a princípio um discurso representativo para um público específico, que possui uma sexualidade outsider: o homossexual masculino. 


\section{As fotografias em G Magazine.}

Para alcançarmos os objetivos deste trabalho, efetuaremos a análise imagética de algumas fotografias publicadas por G Magazine entre janeiro de 2001 e dezembro de 2004. Estas fotografias, escolhidas como representações do universo gay, são partes das seqüências que formaram os ensaios fotográficos veiculados pela revista neste período.

O trabalho analisa a fotografia e sua aplicação a algumas representações publicadas na revista. Tendo em vista o conteúdo sexual das imagens, com o auxílio dos fundamentos sobre sexualidade avaliar-se-á o discurso de G Magazine, mantido por intermédio da linguagem de corpos-signos - as seqüências fotográficas - exibida nas páginas da revista e utilizada para estruturar simbolicamente o seu discurso.

Como primeiro passo, faz-se necessária uma classificação mais específica do teor geral das fotografias constantes destes ensaios. A $G$ Magazine, segundo advertência expressa nas suas capas, é uma publicação de 'conteúdo erótico'. Para fins de classificação deste gênero, este estudo partirá do conceito de Roland Barthes em A câmara clara.

Nesta obra o autor delineia o que seria o limite entre o erótico e 0 pornográfico. Segundo ele, 
"a pornografia representa, costumeiramente, o sexo, faz dele um objeto imóvel (fetiche), incensado como um deus que não sai do seu nicho. A foto erótica, ao contrário (...), não faz do sexo um objeto central; ela pode muito bem não mostrá-lo; ela leva o espectador para fora de seu enquadramento" (BARTHES 1984:88-9).

Para Barthes, a imagem erótica tem um tom de implícito, de não exibir abertamente o sexo como objeto central. A fotografia erótica, assim, dependeria do seu espectador que, interagindo com a imagem, sairia do enquadramento desta. Adauto Novaes salienta que "o olhar deseja sempre mais do que the é dado a ver" (NOVAES 1995:9). A partir desta interação, o espectador busca fora do enquadramento o que 'não Ihe é dado a ver': dar-se-ia a concepção imagética do sexo no imaginário do espectador. Quem olha o erótico, imagina o sexo nele implicitamente representado.

Já no caso da pornografia, ainda segundo Barthes, esta interação para fora do enquadramento entre a imagem e o imaginário do espectador para uma 'visualização' do sexo não se faz necessária: o sexo está ali, explicitamente, exibindo-se para ser visto por todos. Um pouco antes na mesma obra, Barthes define fotografia pornográfica

"como uma vitrine que mostrasse, iluminada, apenas uma única jóia, ela é inteiramente constituída pela apresentação de uma única coisa, o sexo: jamais objeto segundo, intempestivo, que venha ocultar 
pela metade, retardar ou distrair" (BARTHES 1984:67).

Na pornografia, para Barthes, o sexo-jóia está em evidência, iluminado na vitrine com todas as luzes e focos voltados para ele. O sexo é o ponto central desta exibição, apresentado em primeiro plano, sem precisar ser imaginado pelo espectador, "jamais objeto segundo", como a jóia na vitrine da loja.

Ao contrário da imagem erótica, que desloca o espectador para fora do seu enquadramento, a imagem pornográfica, explícita, consuma a interação com seu observador apresentando, no seu próprio enquadramento, o sexo como foco central. Neste mesmo sentido, Arlindo Machado reforça as palavras de Barthes quando salienta que na

"fotografia pornográfica (...) o que o espectador vê na foto não é simplesmente a [pessoa] nua, mas uma [pessoa] nua que posa para ele, que expõe sua plástica para ele, que the sorri e Ihe deposita o olhar, que se oferece toda à sua embriaguez voyeurista" (MACHADO 1984:100).

O corpo da fotografia pornográfica se oferece ao espectador. Ela não simplesmente apresenta o sexo, mas apresenta o sexo para o seu observador, pelo olhar do(s) protagonista(s) da fotografia, pela exposição crua do que a moral social judaico-cristã convencionou que deve ser encoberto, pela manifestação explícita de prazeres proibidos. Tendo em mente tais idéias, segue reprodução de uma página de G Magazine para análise. 


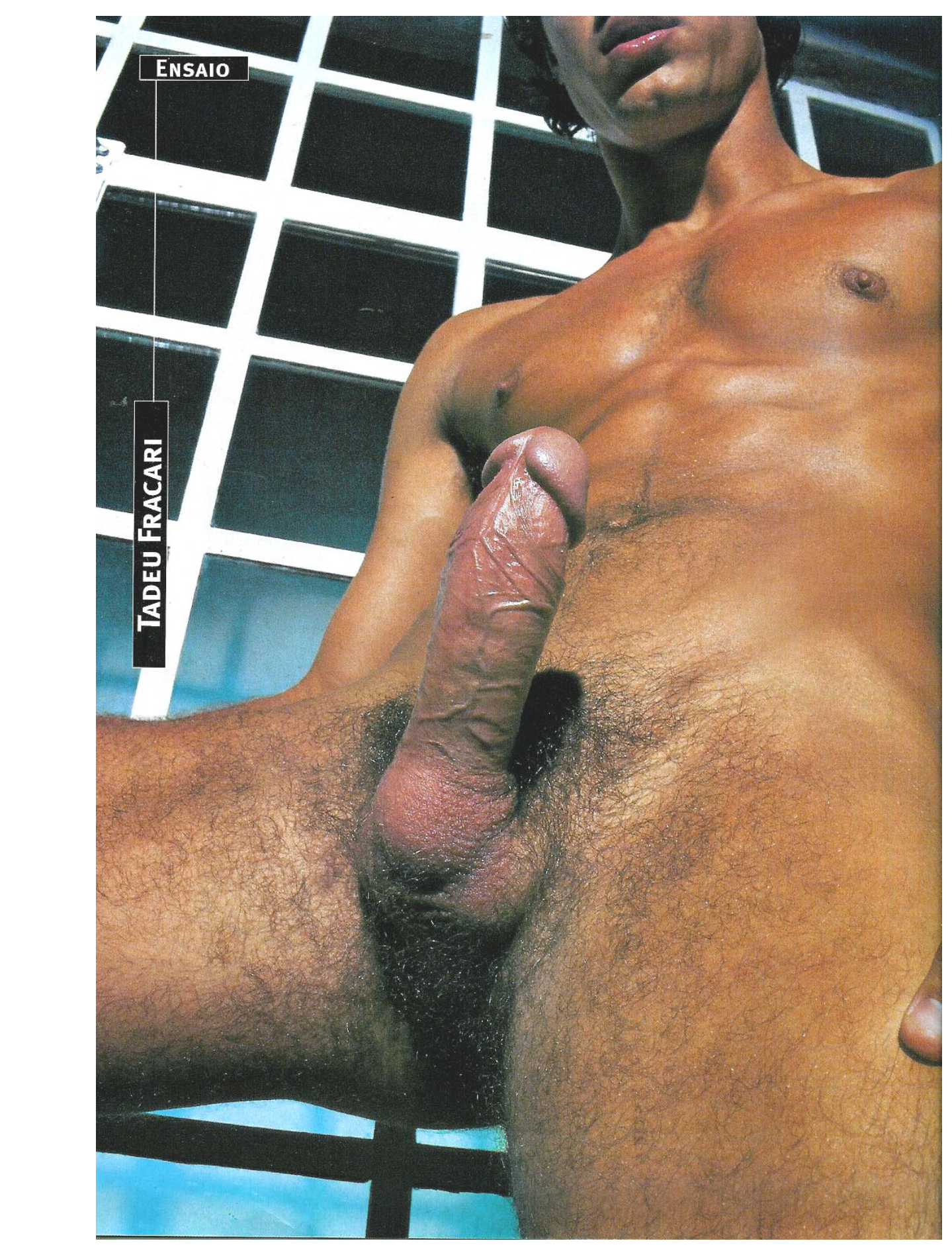

G 52, p. 46

A fotografia pornográfica é "como uma vitrine que mostrasse, iluminada, apenas uma única jóia (...), o sexo: jamais objeto segundo, intempestivo, que venha ocultar pela metade, retardar ou distrair" (BARTHES 1984:67). Nela tudo pode ser omitido - até o rosto do modelo-, mas o sexo é jóia iluminada, foco principal, jamais objeto segundo. 
Na página reproduzida, temos a representação de um corpo masculino jovem. A imagem nos permite a visualização incompleta do corpo-signo do modelo. Como plano de fundo temos apenas uma parede que apresenta linhas brancas verticais e horizontais que formam uma espécie de 'grade'. A fotografia possui um enquadramento que exerce um recorte sobre o corpo-signo, expondo basicamente o seu dorso, partes dos membros (os inferiores acima dos joelhos, 0 bíceps do membro superior direito e o dedo polegar da mão esquerda), além da parte inferior do rosto e, como objeto fisicamente central desta estrutura anatômica, a região pubiana do protagonista, a qual ostenta o pênis em ereção.

Com base na fotografia publicada por $G$ Magazine acima reproduzida, e aplicando a esta o conceito estabelecido por Roland Barthes acerca das noções de erótico e pornográfico, bem como levando em conta as considerações de Arlindo Machado, aplicam-se às imagens analisadas os princípios teóricos de um material com conteúdo pornográfico. Como veremos, os ensaios fotográficos publicados por G Magazine estão, em sua grande maioria, centralizados na exibição de uma única jóia, fazendo do sexo objeto central de representação explícita, e cuja imagem conta com um protagonista que se exibe e se oferece ao olhar do espectador. A maior parte destas imagens exibe o falo como foco principal, mas reserva espaço ao olhar do modelo, que tenta atrair o espectador. 
Partindo dos princípios esboçados por Richard Johnson (2000) acerca do recorte de pautas em mídias contemporâneas, a publicação de material específico por um veículo de comunicação cujo público-alvo é, de forma clara, socialmente segmentado, trata-se de enraizamento e fortalecimento do tom de uniformidade dos leitores como grupo social. O nu masculino explícito e com ereção é a linguagem mais freqüentemente utilizada pela $G$ Magazine na estrutura principal do seu discurso: os ensaios fotográficos. Neste sentido, segundo Luiz Gonzaga Motta (2002), o veículo tem o poder de cumprir o papel de poderoso instrumento legitimador de comportamentos e/ou tendências de consumo.

Umberto Eco, em Apocalípticos e integrados, afirma que "não há forma de criação coletiva que não seja medida por personalidades mais dotadas, feitas intérpretes de uma sensibilidade da comunidade onde vivem" (ECO 1979:54). A mídia segmentada encaixa-se como uma luva neste exemplo de Eco: alguns mantenedores interpretam as exigências do coletivo, representando-as em escala maior pela veiculação. $G$ Magazine pretende-se cumpridora deste papel mediante o público gay e, para tanto, exercerá ativo papel na escolha e manuseio dos corpos-signos estruturais do seu discurso. 


\section{A linguagem do sexo: um corpus de corpos.}

A manipulação do uso do signo é fundamental para nortear o processo de representação, direcionando o sentido que o discurso terá. A escolha da linguagem, composta pelo corpo-signo e sua contextualização no caso dos ensaios fotográficos de G Magazine, exerce função central na elaboração de um discurso voltado especificamente para um público.

Temos utilizado neste trabalho a expressão "corpo-signo" para designar as principais representações imagéticas veiculadas por G Magazine. Assim, no caso desta revista, a manipulação do signo significará, conseqüentemente, a manipulação do corpo, aquele que se exibe na fotografia: um corpo manipulado para se mostrar como explícita e fundamentalmente sexual, tendo como foco central a exibição do sexo, sempre objeto primeiro, nunca oculto.

Eunice Tomé comenta que "o exibicionista do corpo nu pode estar se sentindo erotizado por despertar o desejo no outro, desejo em forma de excitação" (TOMÉ 2002:59). A excitação do outro, do voyeur, alimenta o exibicionista, é combustível que move a ação do apresentar-se como objeto de

observação e, conseqüentemente, de desejo. A anatomia do corpo-signo é manipulada, direcionando o foco da atenção do leitor e, conseqüentemente, a interpretação imaginária construída sobre a representação. 
José Gil lembra que "se o meu corpo se oferece à partida, à vista de outrem, é porque o sei capaz de olhar" (GIL 1996:47). O exibicionista tem consciência do ser olhado, da necessidade do observador em ver, e se embriaga no seu afã de se mostrar.

Estabelece-se, portanto, uma cumplicidade entre o que olha e o que é olhado, entre o exibicionista e o voyeur, cumplicidade estabelecida pela relação entre o que os olhos buscam e o que a imagem pornográfica prontamente exibe. O espectador, inebriado pela sua libido, é dominado pela imagem, pelo que está ali, a olhos vistos, com aparência de muito mais próxima da realidade que uma idéia de produto imaginário, provocada pela interação concebida pela imagem erótica.

A G Magazine, para defender sua postura, escolherá signos com representatividade específica no sistema sígnico pertencente ao grupo social formado pelo seu público-alvo. Pelo contexto, a fotografia torna-se pedaço da linguagem estruturadora de um discurso, nunca neutra. Roland Barthes simbolicamente lamenta: "Ah, se ao menos a fotografia pudesse me dar um campo neutro, anatômico, um corpo que nada signifique!" (BARTHES 1984:24). As fotografias em G Magazine, como ensaio, formam um corpus de corpos que algo significam, uma linguagem cuja exposição pornográfica constrói uma espécie de exacerbação do significado do nu masculino, e tal representatividade existe na impossibilidade destas fotografias exibirem um 'campo neutro'. 
O corpo ocupa lugar de destaque na mídia hoje. Eunice Tomé comenta que o corpo físico "tem sido colocado à venda e mostrado incansavelmente com o objetivo de provocar reações, quer de erotismo nos meios de comunicação, quer no próprio dia-a-dia para provocar desejo e conquista" (TOMÉ 2002:52). A funcionalidade do corpo na comunicação é quase automática, incitada pelo desejo do espectador de posse deste corpo, seja como seu próprio, seja como do outro que o completa. Quem vê, deseja, e quem se exibe também deseja: deseja sentirse admirado.

Este corpo, para além de ser a sede pulsante da vida biológica, envolvido por um tecido que protege o trabalho silencioso dos órgãos, tomou uma importância que expande em muito os horizontes do seu papel na sociedade contemporânea. Maria Rita Kehl analisa brevemente o lugar ocupado pelo corpo hoje, chegando a traçar um paralelo entre este e o nível de felicidade que poderá ser alcançado pelo sujeito. A psicanalista alerta:

"Fique atento, pois o corpo que você usa e ostenta vai dizer quem você é. Pode determinar oportunidades de trabalho. Pode significar a chance de uma rápida ascensão social. Acima de tudo, (...) o corpo que resume praticamente tudo o que restou do seu ser é a primeira condição para que você seja feliz" (KEHL 2002:18). 
Este corpo, alçado à condição sine qua non para se alcançar a felicidade, é colocado em exposição no que a autora chama de 'mercado das trocas imaginárias' (Idem), sendo oferecido ao olhar alheio para garantir um lugar no palco das visibilidades em que se transformou o espaço público no Brasil. O corpo torna-se, portanto, centro de demonstração de poder: se o sujeito ostenta um determinado corpo, a ele são outorgados direitos, inclusive o direito à felicidade. Vias e oportunidades parecem ser abertas pela vida, desde que este sujeito esteja disposto a oferecer seu corpo - cuidadosamente preparado - no mercado das trocas imaginárias.

Tal poder conferido ao corpo faz com que este seja tomado por uma aura de poder: quem possui um corpo de alto valor para o mercado das trocas, possui poder. Este poderoso corpo passa a ser venerado, como um objeto de adoração.

O corpo é como um templo que guarda na sua essência, na sua sexualidade, o objeto de adoração. Como salienta Jean Baudrillard, o corpo é 'objeto de salvação':

"A panóplia do consumo, o mais belo, precioso e resplandecente de todos os objetos, é o corpo. A sua redescoberta (...) sob o signo da liberdade física $e$ sexual, a sua onipresença na publicidade, na moda $e$ na cultura de massa, a obsessão pela juventude, elegância, virilidade, cuidados, regimes, práticas sacrificiais que com ele se conectam, o 'mito do 
prazer' que o circula - tudo hoje testemunha que 0 corpo se tornou objeto de salvação" (BAUDRILLARD 2000:206).

No mundo contemporâneo, o corpo é apresentado para ser consumido, mesmo que no sentido figurado. A perfeição das formas é uma necessidade, que faz com que o objeto de salvação equipare-se à figura religiosa daquele que pode conduzir à salvação espiritual, por sua vez descrito como perfeito. É por intermédio do corpo que o sujeito vai se mostrar à sociedade, e a partir dele que esta criará uma figura imaginária representativa de um todo idealizado: e quanto mais próximo da idealização imaginária estiver este corpo físico, mais ele valerá como moeda de 'trocas imaginárias'. Quanto mais o corpo-signo puder ser objeto para 0 qual a libido penda para suprimento da demanda da pressão orgânica característica da pulsão sexual do sujeito, mais este corpo-signo poderá ser utilizado pela mídia como forma de linguagem persuasiva, como objeto de consumo.

Está criado o que Baudrillard intitula de o 'mito do prazer'. É este corpo preparado que tem alto valor no mercado das trocas imaginárias. Em um mundo onde noções de identidade são relativizadas, e no qual o sujeito encontra-se cada vez mais multifacetado e fragmentado, conforme elementos da pós-modernidade apontados pelos Estudos Culturais, o sujeito precisa se estruturar, se construir a partir de várias perspectivas diferentes. Um corpo-signo que se apresente em meio 
a este caos como a idealização da 'inteireza', com a ilusão de ser completo e de poder corresponder aos anseios das demandas psíquicas, surge como o grande objeto de salvação, como o guia o qual não se pode perder de vista, o qual deve ser seguido de perto e deverá servir como fonte de inspiração, como exemplo a ser glorificado, idolatrado. Está constituído imaginariamente o mito do prazer, que serve como válvula de escape aos perenes anseios do sujeito faltante.

A utilização de artifícios gráficos para 'aperfeiçoar' as formas dos corpos, hoje costumeiros na comunicação, não é novidade para nenhum consumidor medianamente esclarecido. Mas, a este dado não se confere muita importância para a relação de sedução do consumidor no processo de compra/venda. Os corpos perfeitos exibidos espetacularmente são para o consumo imaginário do espectador.

Hal Foster enfatiza que,

"ao contrário de uma representação que trabalha mediante nossa fé em seu realismo, o espetáculo opera mediante nosso fascínio pelo hiper-real, pelas imagens perfeitas que nos fazem inteiros ao preço da ilusão, da submissão" (FOSTER 1996:58).

A ilusão da inteireza, impossível de consumação real, pretende-se conquistada no imaginário com o auxílio de formas e contornos que, igualmente, 
são impossíveis no real, mas com o auxílio gráfico, por exemplo, concretizam-se na imagem e no seu consumo imaginário.

Esta possibilidade de manipulação gráfica da fotografia, na verdade, faz com que esta se afaste daquele teor de aproximação fiel da realidade lembrado por Dubois. Mesmo assim, a ilusão sustentada por esta idéia de conexão física com a realidade se mantém, vendendo um produto que, pelo exagero de suas características 'positivas', só se faz passivo de consumação no imaginário, satisfazendo desejos de consumo e prazer.

Com este leque de fácil manipulação aberto pela imagem, e de abrangência tão reconhecida junto ao público, a fotografia constitui-se em uma ferramenta adequada para o enraizamento e o fortalecimento de idéias, quando publicada por um veículo de comunicação voltado a um segmento social específico. Então, vendo neste fenômeno de consumo um interessante nicho econômico, a sociedade capitalista vai saturar o mercado da informação segmentada alimentando demandas sociais de identificação e diferenciação sócio-político-comportamental.

O resultado deste processo econômico: uma infinidade de tipos de publicações que tratam dos mais variados assuntos, para os mais variados públicos que constituem aquele mosaico social contemporâneo. A sexualidade, como característica da natureza humana que - de alguma forma - atinge a todos, torna- 
se fonte quase inesgotável para representação de suas inúmeras facetas numa mídia voltada para o consumo que cada vez mais se focaliza em prover as respostas para as demandas segmentadas.

O consumo imaginário dos corpos-signos torna-se ainda mais intenso pela atuação da libido e de todo o mecanismo bio-psicológico que estrutura a sexualidade humana. G Magazine expõe corpos-signos a serem co(nsu)midos no imaginário do leitor. 


\section{O nu masculino como linguagem.}

O nu feminino, pela histórica associação da figura da mulher com a beleza estética e a natureza, tem presença constante e socialmente legitimada como objeto de desejo na comunicação. A mitificação do feminino, comumente ligado aos engodos da sensualidade de um ser envolvente pela beleza, começa muito longe na História, passando pelas figuras da persuasiva Eva judaico-cristã, da egípcia Cleópatra, da semi-deusa Afrodite e Helena gregas, a Vênus romana e outras tantas, chegando às atuais estrelas do cinema e da televisão, às misses vencedoras de concursos de beleza e às beldades das passarelas de moda. São traços da oposição entre a mulher-natureza e o homem-cultura, mencionadas pelo historiador francês Jules Michelet.

Esta ligação da mulher com a natureza estudada por Michelet, um dos precursores no resgate desta dimensão do imaginário social construído sobre a mulher, é relevante. Na sua conhecida obra La Sorcière, Michelet indica que foi a Natureza que fez da mulher a feiticeira.

Sem cair na questão levantada pelo autor, que opõe a "mulher-natureza" ao "homem-cultura", pretendemos afirmar que o que se poderia chamar "a natureza feminina" é também uma construção simbólica, fruto de uma representação atribuída e dada pelo olhar dos homens sobre as mulheres, segundo a obra de Michelet. O historiador enfoca bem a questão quando centraliza sua análise num 
aparente paradoxo: é justamente no momento em que a mulher emerge como uma personagem de maior presença na história que é preciso diabolizá-la.

É naquele momento, na passagem do século XIV para o século XV, em que se acentua a sua faceta de bruxa, de sexualidade desregrada, dotada de malícia, capaz de realizar sortilégios e malefícios. Mais do que isso: esta representação feminina trabalha com a idéia de que a mulher é perigosa, por ser capaz de trair e seduzir pela sua beleza instintiva, "natural".

Ao longo dos séculos que comportam as Idades Moderna e Contemporânea, a figura feminina continuou sendo colocada como elemento natural a ser domado. Especialmente nas culturas ocidentais, a criação das meninas tem características mais rígidas que a dos meninos. A mulher idealizada pela estética romântica, por exemplo, deveria se aproximar dos padrões divinos de aspecto e comportamento. O feminino não-divinizado era cercado de engodos, especialmente ligados à carne. Fortalece-se a figura da prostituta, personagem freqüente, marcante e, via de regra, transgressor no imaginário social construído ao longo dos séculos.

Pela natural associação da prostituta ao 'mito do prazer', a construção simbólica desta figura é marginalizada e, ao mesmo tempo, glamourizada. As 'mulheres fatais', que conseguem atingir seus objetivos engodando os homens utilizando-se de sua 'beleza natural', ocupam posição privilegiada nos desejos 
masculinos. O surgimento do cinema e das divas avassaladoras concedeu à figura do feminino um apelo de objeto de desejo dotado de ferramentas que instigam os instintos do 'homem-cultura', fazendo-o muitas vezes perder a razão. Esta ferramenta localiza-se socialmente sob o signo de 'beleza'.

A idolatria pela beleza e fatalidade femininas é bastante difundida, criando verdadeiros símbolos de glamour em torno daquelas que ostentam os padrões físicos vigentes na sociedade, com alto poder de sedução pelos 'adornos naturais'. Suas imagens - independente do grau de fidelidade que têm com seus referenciais - serão utilizadas à exaustão pela mídia, no afã da venda de produtos, da sedução do consumidor. A mulher 'selvagem' se oferta ao homem 'civilizado' como objeto de satisfação, um animal instintivo a ser domesticado pelo dominador.

A posição 'mulher-objeto' consolida-se na mídia contemporânea: a exposição do corpo feminino nos comerciais de cerveja, nas demonstrações de roupas intimas em catálogos, nas propagandas de academias e centros de estética, nos sofisticados desfiles de moda, nos editoriais de revistas famosas, em apresentações de danças, na indispensável ajuda das numerosas assistentes de palco em programas de $\mathrm{TV}$, num sem-fim de situações que apelam à exibição do corpo feminino para deleite daqueles que, por intermédio desta contemplação, suprem a demanda por prazeres proibidos mencionada por Freud. Independentemente do seu sexo biológico, estes contempladores ocupam a 
posição do masculino no consumo destes corpos reificados, postos à disposição como moeda de peso nas trocas imaginárias.

Já o corpo masculino em nu explícito, frontal e com ereção não se configura hoje em uma linguagem convencionalmente utilizada de forma explícita na mídia. O homem-cultura de Michelet, oposto à mulher-natureza, é lógico, racional, nãoinstintivo, não-natural, não passível de se tornar objeto manipulável - isso ocorreria apenas pela perda momentânea da razão e pelo descontrole causados por uma explosão do instinto animalesco. O masculino é agente, controla a natureza, e a mulher-natureza. Homem como objeto não é muito convencional no Ocidente. Este papel de objeto, fora do eixo de comando e poder, comumente cabe à figura feminina. Reflexos de uma sociedade falocêntrica.

Várias questões estão implicadas neste contexto: em sua maioria apontando para a estrutura religiosa da moral judaico-cristã, patriarcal e conservadora. O divino é o poder maior, e é masculino (Deus-Pai). Seu nome não deve ser pronunciado em vão. Sua figura não é visível, portanto, 'nãorepresentável' imageticamente. O pênis sustenta a masculinidade, é o símbolo do poder, é o símbolo do pai, reflexo do divino. Howard Eilberg-Schwartz (2005) discute alguns elementos da psicanálise freudiana acerca do pênis como sustentação da masculinidade e sua influência na cultura religiosa ocidental de fundo judaico-cristão. 
Desta forma, o pênis é divinamente símbolo do pai-poder e não deveria ser vulgarmente representado, exibido, 'publicado em vão'. A aura que envolve o pênis, assim, se aproxima da aura do temor divino, impondo toda a respeitabilidade que se cabe à imagem daquele que é o soberano universal refletida numa espécie de temor piedoso do pai, do poder, do pênis.

Além disso, há o peso religioso da transgressão e do pecado na cultura judaico-cristã que recai sobre a pornografia em geral. Em meados do século XII, o cristianismo instituiu a luxúria como pecado capital e, por conseqüência, a pornografia como representação angular deste pecado. Representações do sexo e dos atos a este ligados, antes um tanto populares no Ocidente pré-pecados capitais, foram relegadas e marginalizadas como práticas condenatórias ao infortúnio daqueles que aderiam a elas. Tais valores morais regem o mundo cristão, estendendo-se até os dias de hoje.

G Magazine destaca-se na mídia contemporânea por utilizar esta linguagem duplamente estigmatizada para construir o seu discurso. É estigma em dobro, primeiramente por ser linguagem pornográfica, pecaminosa, e segundo por ser uma pornografia de representação do masculino, dois elementos localizados fora do eixo social de poder. 


\section{Um discurso de poder.}

As posições da mulher-objeto e do homem-dominador, estabelecidas historicamente e reforçadas pela mídia, podem ser observadas pela forma como ambos os corpos-signos (o masculino e o feminino) são vendidos como moeda de valor para as trocas imaginárias. A simbologia de marcadores anatômicos que estabelecem a diferenciação biológica da sexualidade constrói um discurso de poder por meio da disposição física com que tais corpos-signos são comumente dispostos à contemplação.

G Magazine tem uma linguagem peculiar para representação do corposigno, que mantém um perfil padronizado. Em todas as edições da revista há, em meio aos ensaios fotográficos, a repetição de imagens nas quais os protagonistas anatomicamente se exibem ao leitor explicitando os caracteres biológicos que os qualificam como masculinos. 


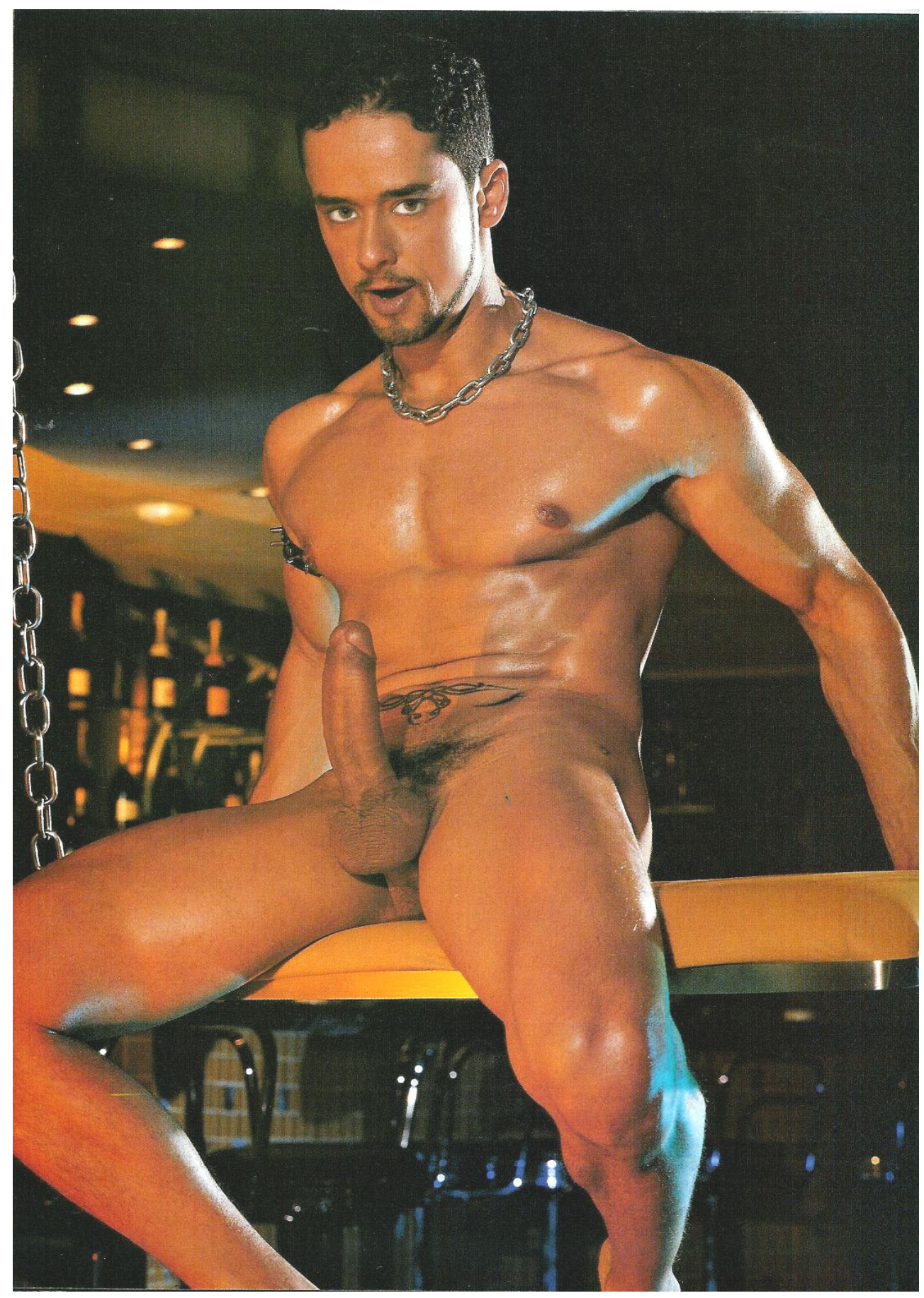

G 72, p. 36

Protagonistas exibem seus caracteres biológicos de masculinidade: a "ereção peniana, em correlação com os temas do 'alto e do baixo', do 'erguido e do curvado', do 'duro e do mole', constituem os símbolos privilegiados da superioridade social e da vontade de poder" (GUIRAUD 1991:50). 
Pierre Guiraud, analisando $A$ linguagem do corpo, detalha aspectos acerca da simbólica da sexualidade. Segundo tais princípios, existe imaginariamente uma associação entre um pênis ereto e as noções de poder e comando. Guiraud estabelece:

"A ereção peniana (...) em correlação com os temas do 'alto e do baixo', do 'erguido e do curvado', do 'duro e do mole', constituem os símbolos privilegiados da superioridade social e da vontade de poder. (...) a etimologia confunde em uma mesma imagem a idéia de 'endireitamento vertical' (erigir, ereção, endireitar, latim directiare etc.) e a de comando (dirigir, diretor, rei, latim rex)" (GUIRAUD 1991:50).

Os ensaios fotográficos da $G$ Magazine têm por característica peculiar a presença da exibição de seus protagonistas com ereção peniana, sendo esta uma clara demonstração de poder, de comando, de ação.

O protagonista do ensaio é o 'rei', aquele que detém o poder, aquele que decide, que comanda, aquele a quem o espectador está subjugado. O rei-sedutor se exibe e domina, toma conta da situação submetendo o olhar do espectadorseduzido.

A relação estabelecida entre eles é de poder, de subjugo. Maria Rita Kehl comenta que "não se pode dizer que o seduzido ame o sedutor - ele é seu prisioneiro. O olhar seduzido é perplexo. Procura recobrar o domínio de si mesmo" 
(KEHL 1995:411). Estabelece-se a relação de domínio, imposta pela demonstração do poderio do masculino representado pelo falo.

O espectador é seduzido pelo poderoso exibicionista, o qual se produziu para obter este resultado de deslumbramento. Em artigo, Maria Rita Kehl reflete sobre a nova relação estabelecida entre o sujeito e o seu corpo na contemporaneidade. Segundo ela, "são corpos em permanente produtividade, que trabalham a forma física ao mesmo tempo em que exibem o resultado" a espectadores atentos e sedentos da exibição.

Ainda, para Kehl,

"são corpos-mensagem, que falam pelos sujeitos. $O$ rapaz 'sarado' (...) ostenta seu corpo como se fosse aqueles cartazes que os homens-sanduíche carregam nas ruas do centro da cidade: 'Compra-se ouro', 'Vendem-se cartões telefônicos', 'Belo espécime humano em exposição'" (KEHL 2002:18).

De acordo com a psicanalista, o discurso por trás desta necessidade da exposição do exibicionista público do corpo produzido é vazio de sentido, e esta visibilidade vazia anula grandemente os sujeitos do desejo e da ação política. "No Brasil de hoje, em que o espaço público foi a um só tempo desmantelado e ocupado pela televisão, a produção dos corpos é a produção da visibilidade vazia", 
finaliza Kehl, indicando ser este processo sinal claro de uma vida fechada diante do espelho (Idem).

O corpo-signo é sinal de poder, em especial quando acompanhado da simbologia divina de demonstração de poder - o pênis. A noção de grandiosidade e poderio exposta pelo protagonista do ensaio de $G$ Magazine é, em linhas gerais, a mesma das arquiteturas pomposas de templos das mais variadas instituições religiosas mundo afora. As formas de demonstração de poder seguem uma mesma linha imagética. Ambas seguem o direcionamento de representação da posse do poder. O falo é o símbolo do poder, e seu proprietário - que vai se preparar, se 'produzir' para exibir seu poder - torna-se digno de idolatria, como um deus.

Por meio das seqüências fotográficas publicadas mensalmente em suas páginas, $G$ Magazine constrói seu discurso oferecendo a seus leitores uma linguagem que mantém o 'lugar do pênis' na rede simbólica. Na sua quase totalidade, as seqüências de fotografias mostram um pênis rígido, ereto, nunca flácido ou aparentemente 'abatido'.

Esta disposição imagética legitima, de forma geral, a noção de poder atribuída socialmente ao pênis e, especialmente, ao seu portador, o masculino. Instauram-se os jogos entre poderes e prazeres designados por Michel Foucault, que outorgam ao macho detentor do símbolo de poder o privilégio de gozar certos 
prazeres barrados àqueles que não são possuidores daquele símbolo e estão, portanto, fora do eixo de poder.

Esta exposição faz parte de um fenômeno que vem se desenvolvendo no mundo contemporâneo há algum tempo. Com um mundo cada dia mais globalizado e, ao mesmo tempo, mais individualista para o sujeito, a construção de um mundo imaginário onde tudo funciona serve como espelho para inspiração daqueles para quem o sistema é mais distante do idealizado. As 'vidas perfeitas' têm de ser falos a servirem de exemplo. A sociedade do espetáculo ganha força, e é uma máquina que não pode parar. 


\section{A sociedade do espetáculo.}

A contextualização dos ensaios fotográficos de G Magazine, que será identificada especialmente pelos trajes, acessórios e ambientações das fotografias, geralmente remete a aspectos da vida profissional e/ou pessoal do protagonista, especialmente o meio pelo qual este se tornou figura de reconhecimento junto ao público. Recuperando as considerações de Pepe Baeza sobre o uso da fotografia na mídia contemporânea, esta é uma forma de legitimar o mundo do espetáculo pela criação/fortalecimento de um processo de mitificação do homem que faz parte deste sistema do entretenimento. O homem mantém-se na mídia, e a mídia lucra com sua exposição não-usual, pornográfica, tudo em nome de manter(-se n)o espetáculo.

Numa das obras mais conhecidas a este respeito, Guy Debord reflete sobre uma Sociedade do Espetáculo que vai muito além da onipresença dos meios de comunicação, que representam somente o seu aspecto mais visível e mais superficial. Debord explica que o espetáculo é uma forma de sociedade paralela em que a vida real é pobre e fragmentária, e os indivíduos são obrigados a contemplar e a consumir passivamente as imagens de tudo o que lhes falta em sua existência real. Eles têm de olhar para outros (estrelas, figuras públicas, políticos etc) que vivem em seu lugar. 
Desta forma, a realidade torna-se uma imagem, e as imagens tornam-se uma realidade; a unidade que falta à vida, recupera-se no plano da imagem. Enquanto a primeira fase do domínio da economia sobre a vida caracterizava-se pelo 'ser em ter', no espetáculo chegou-se ao reinado soberano do 'ser em aparecer'. As relações entre os homens já não são mediadas apenas pelas coisas, mas diretamente pelas imagens.

Para Debord, no entanto, a imagem é uma abstração do real, e o seu predomínio, isto é, o espetáculo, significa um "tornar-se abstrato" do mundo. No espetáculo, a economia, de meio que era, transformou-se em fim, a que os homens submetem-se totalmente, e a alienação social alcançou o seu ápice: o espetáculo é uma verdadeira religião terrena e material.

Expor corpos produzidos no intuito de aguçar o desejo do espectador é uma forma de espetacularizar a sociedade. Em G Magazine, a utilização de certos signos, usualmente embebidos em conotação sexual, será compreendida pelo leitor se este entender a posição ocupada no dado momento por aquele signo no imaginário social: serão signos que remeterão à 'vida real' (pessoal ou profissional) do protagonista do ensaio, levando o sujeito a ocupar automaticamente um lugar nesta paralela sociedade do espetáculo. 
O protagonista aparece no ensaio fotográfico da edição 69 de $G$ Magazine sustentando uma corrente pela base do pênis ereto. Tal signo é referencia de sua participação em um quadro chamado 'Acorrentados 2 - A Revanche', exibido em 2002 pelo programa 'Caldeirão do Huck', da Rede Globo de Televisão. Neste quadro, um grupo de homens jovens manteve-se acorrentado a uma garota durante vários dias, na disputa pelo direito de cortejá-la em namoro. Por intermédio desta participação no programa, o jovem surgiu para o público. 0 modelo é levado da 'realidade' para o espetáculo por intermédio da imagem.

A fotografia mantém o discurso característico do símbolo de poder representado pelo pênis ereto, uma freqüente nas seqüências fotográficas da revista. A espetacularização da exibição dos corpos em imagens profundamente sexualizadas como objetos a serem idolatrados e consumidos, percorrendo Foucault, Guiraud, Kehl e Debord.

A construção de sentido na mente do espectador, dada a predominância imaginária da interpretação aberta pela fotografia, pode ser conduzida por aquele que fotografa, manipulando mecanismos como foco, luz, perspectiva e ambientação, bem como os efeitos gráficos do processo de 'aperfeiçoamento do material'. Estes e outros elementos presentes podem servir como norteadores para direcionar a representação esboçada pela função significante da imagem. 
Como foco principal da fotografia pornográfica, o sexo, bem como o corpo físico que o sustenta, são colocados em perspectivas e ambientações que, em contato com a libido do espectador, ajudam a 'guiar' o entendimento deste, estruturando o discurso e, desta forma, reforçando uma mensagem.

Quanto a este processo de estruturação de um contexto imagético no qual se imbui um signo especifico - neste caso, o sexo -, John Berger enfatiza que a fotografia,

"ao mesmo tempo que faz suas próprias referências à imagem do original, torna-se ela própria o ponto de referência para outras imagens. $O$ significado de uma imagem muda de acordo com o que é imediatamente visto ao seu lado, ou com o que imediatamente vem depois dela. Essa autoridade que ela detém é distribuída por todo o contexto em que aparece" (BERGER 1999:31).

Pelas palavras de Berger entende-se que 0 sexo representado explicitamente na fotografia pornográfica ganha conotações específicas de acordo com o contexto no qual ele está inserido. Assim, o foco central da imagem fotográfica acaba sendo diretamente influenciado, em sua instância de representatividade, por signos que o acompanham, que dividem a cena do enquadramento imagético, bem como pelo todo constituído pela revista - veículo 
segmentado, voltado a um público específico. Desta forma se constrói o contexto de exibição do foco.

Em G Magazine, constrói-se o contexto para a exibição do sexo como a jóia da vitrine. Esta jóia está contextualizada em meio a um cenário e objetos de figuração que criam uma ambientação, auxiliando na lógica do sentido representada pela seqüência do ensaio fotográfico, criando e/ou fortalecendo mitos e estereótipos de virilidade e masculinidade no imaginário social, especialmente do segmento homossexual masculino. As posições e comportamentos ligados ao ato sexual, bem como uma ambientação cenográfica que tende a inflamar a ação da libido, são constantes nos ensaios fotográficos da revista.

Como exemplo do acima, nas próximas páginas foi reproduzido na íntegra de um ensaio fotográfico de capa em $G$ Magazine, seguido de breves considerações. Intitulado As Travessuras do Muleke, o ensaio traz o cantor do grupo de pagode 'Muleke Travesso', e foi publicado na edição 43 da revista, datada de abril de 2001. 

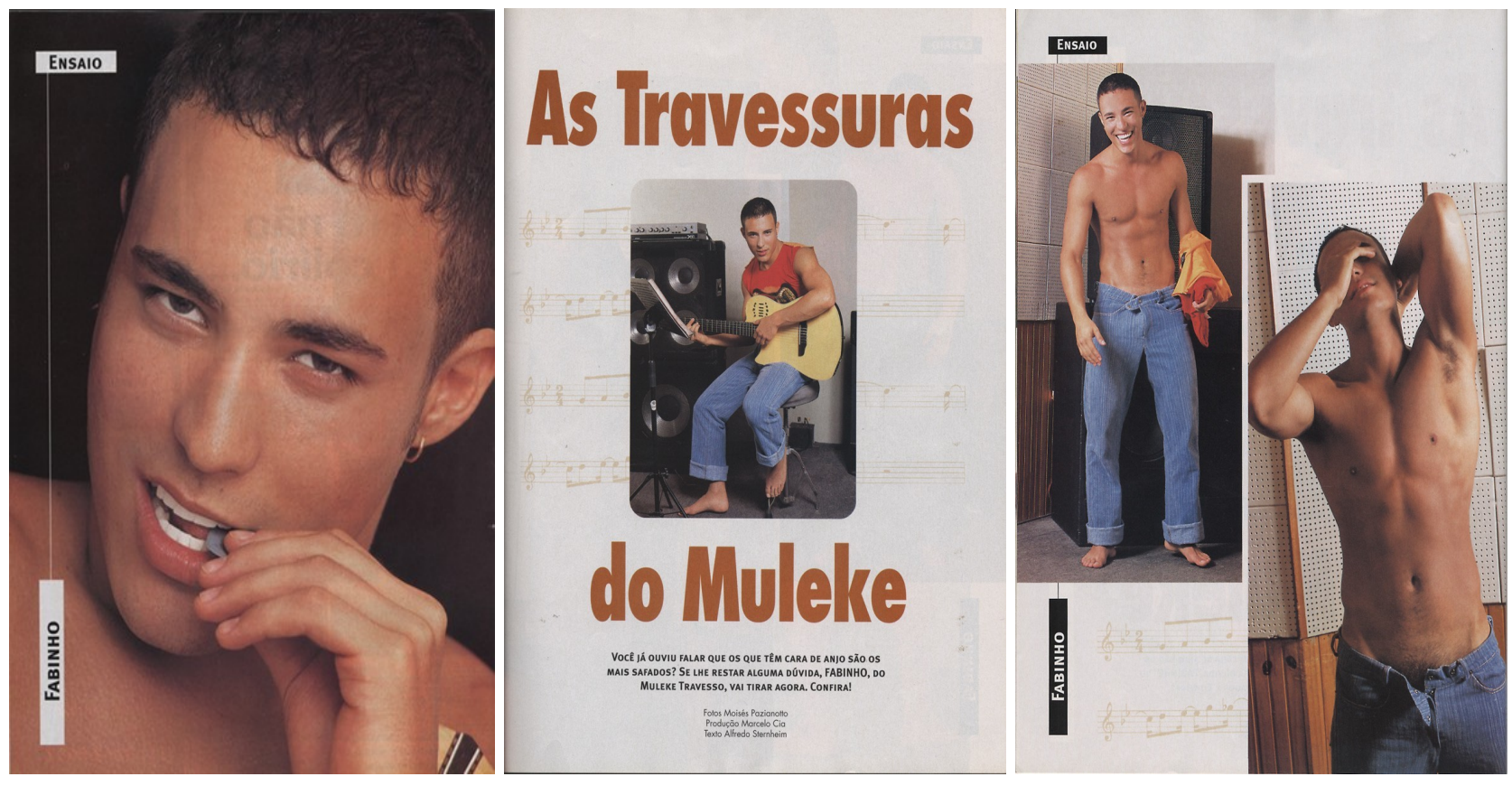

G43, p. 34-6
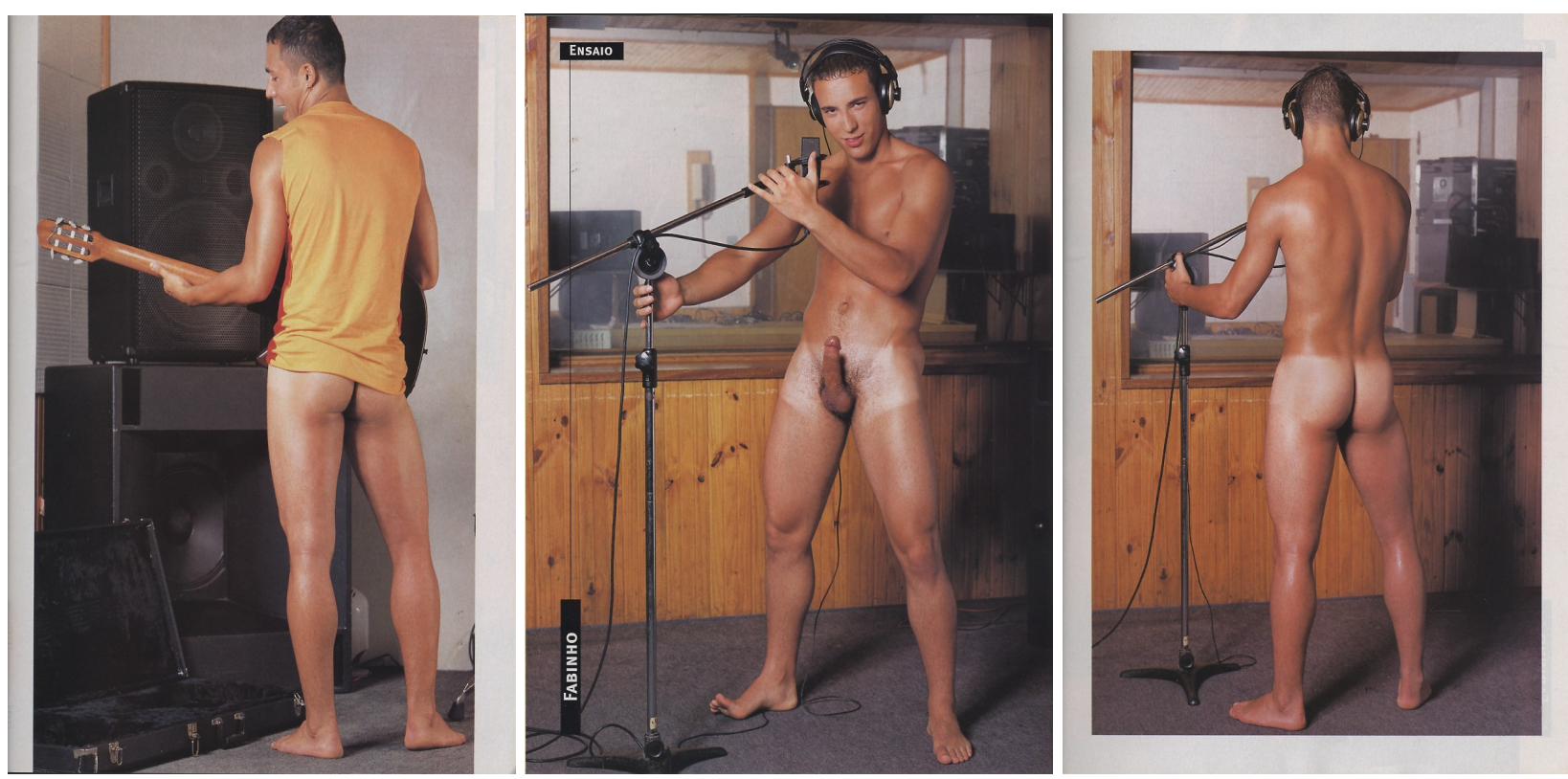

G43, p. 37-9 

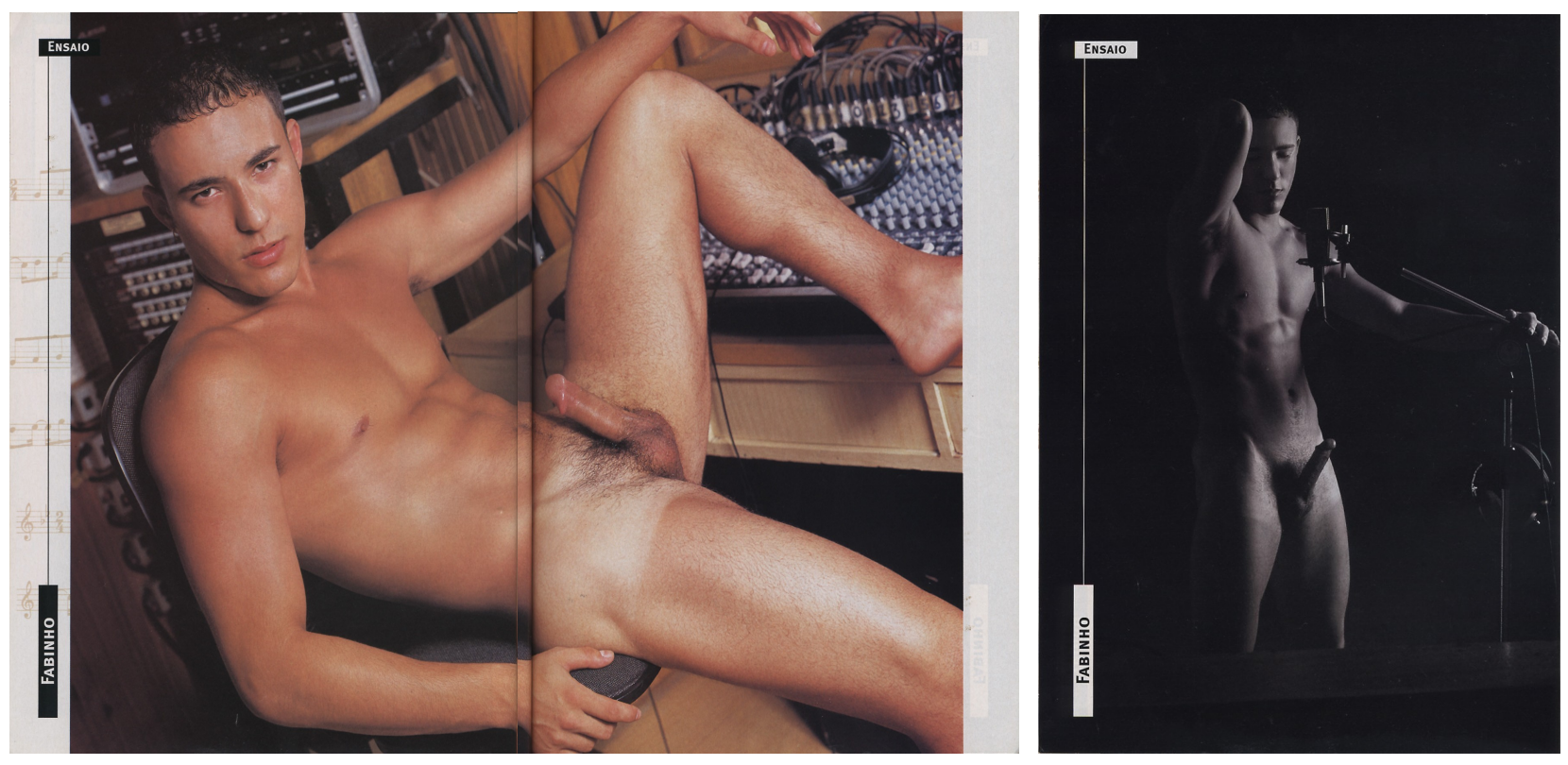

G43, p. 40-2
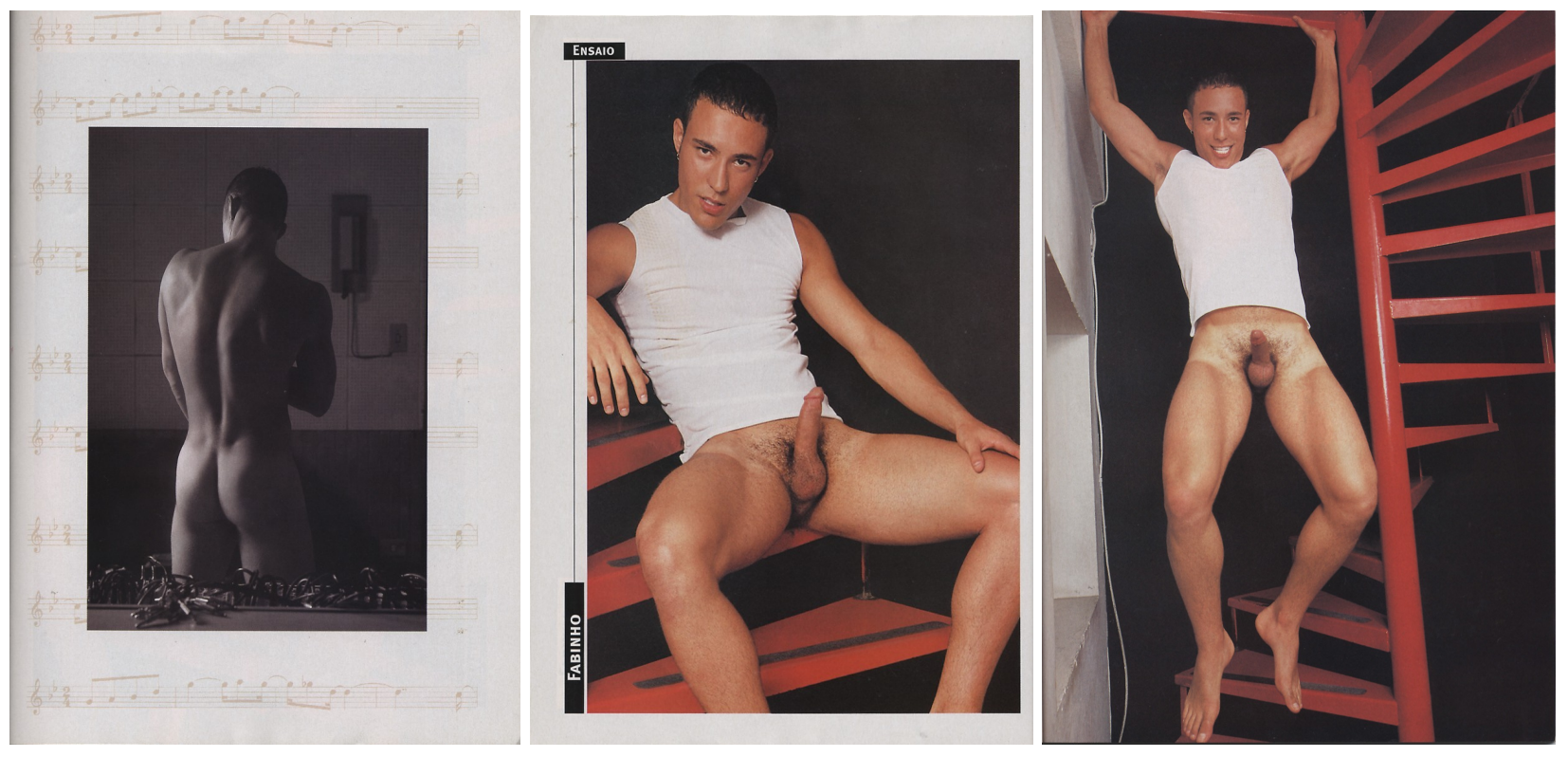

G43, p. 43-5 

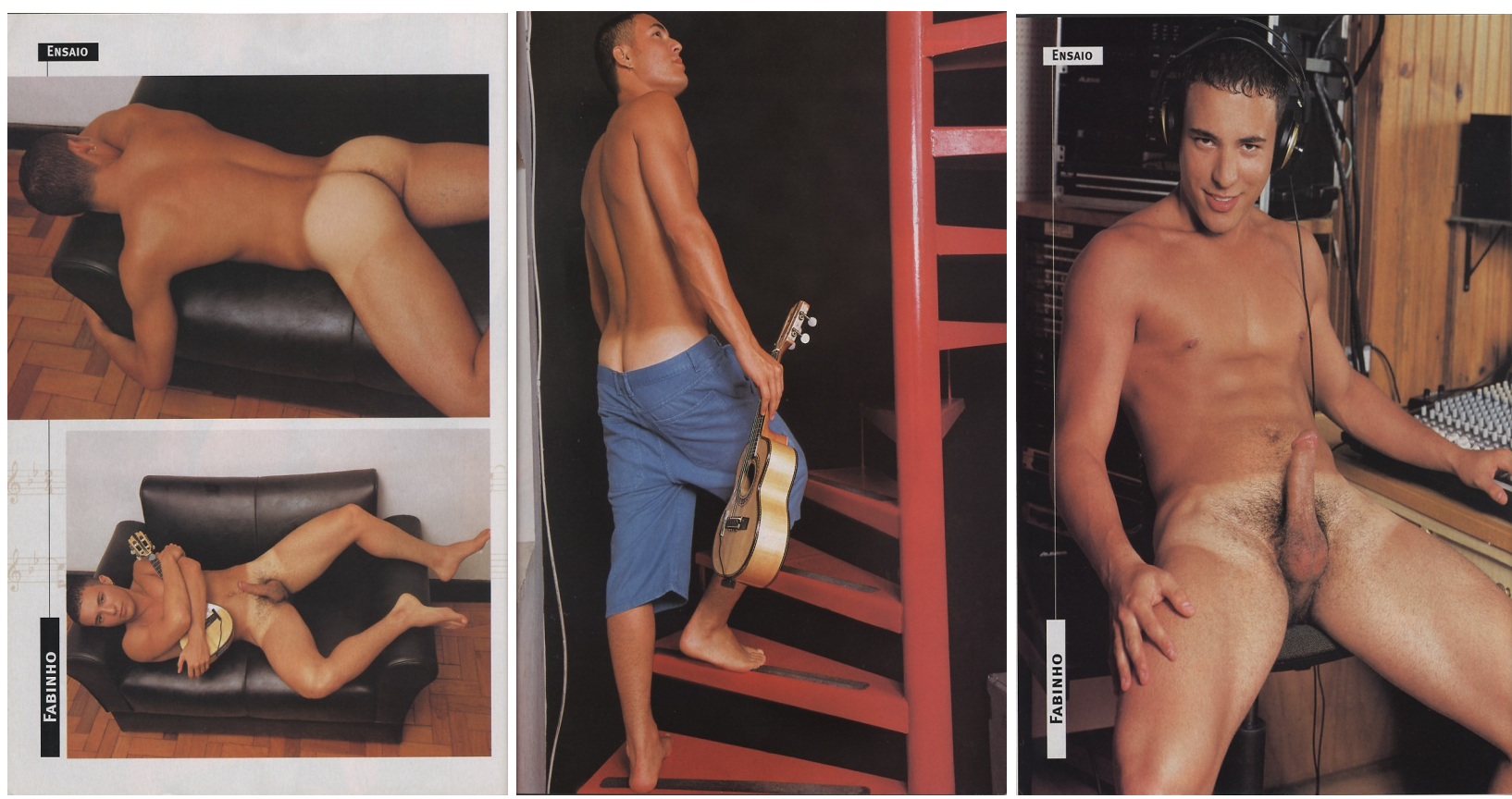

G43, p. 46-8
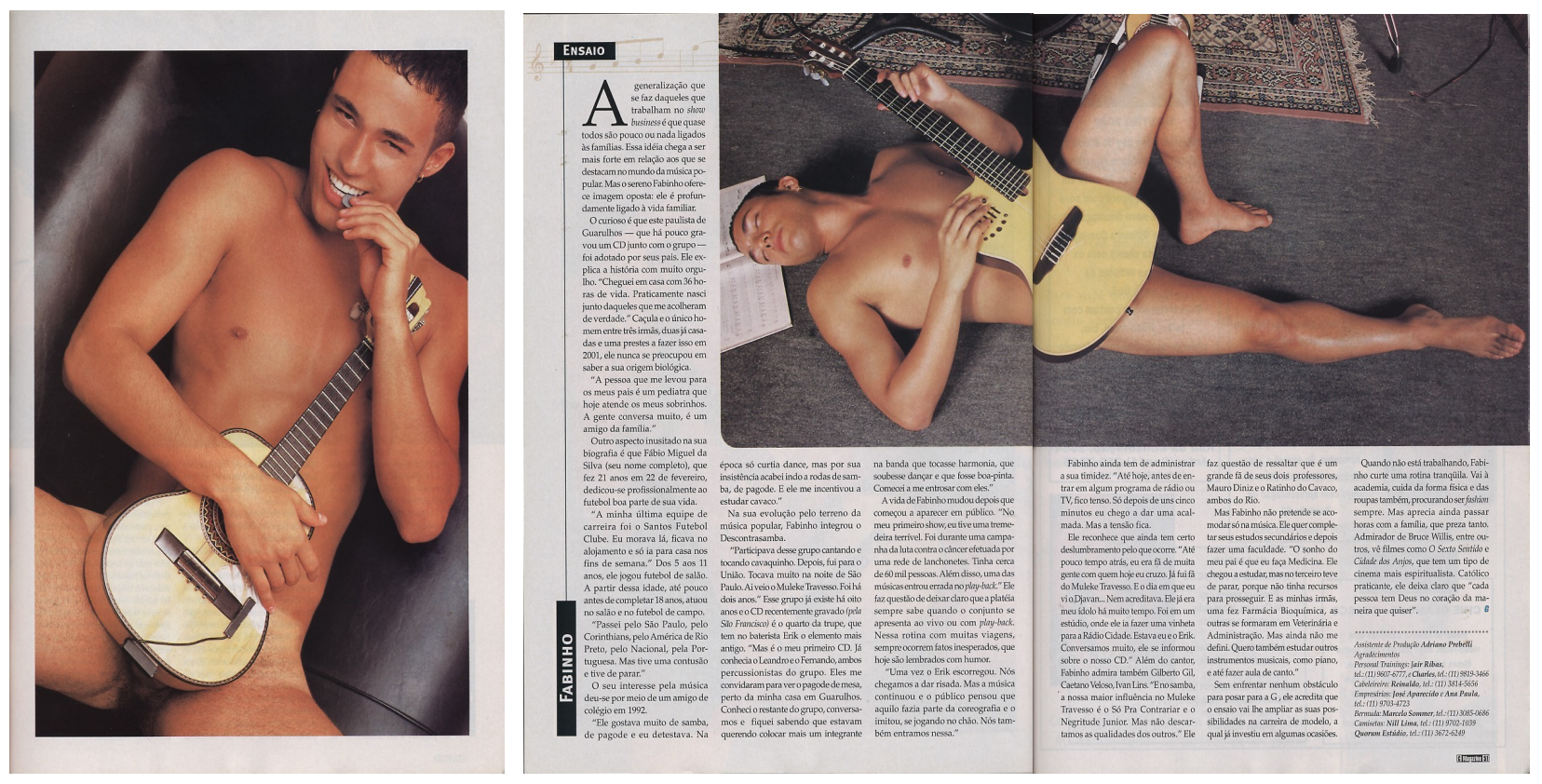

G43, p. 49-51 
Este ensaio fotográfico estende-se por 18 páginas da edição 43 de $G$ Magazine. A seqüência é composta por um total de 18 imagens do protagonista, sendo que nas páginas 36 e 46 são apresentadas duas fotografias em cada, enquanto que uma mesma representação ocupa as páginas 40 e 41, e outra estende-se entre as páginas 50 e 51 . Esta última está acompanhada de um texto que traçaria o perfil "familiar" do modelo, contando com breves citações de falas do protagonista, ao estilo entrevista.

Fabinho aparece totalmente nu em oito imagens (p. 34, 38, 40-41, 42, 43, 46 [superior] e 48), acompanhado de instrumentos musicais de cordas em seis fotografias (p. 35, 37, 46 [inferior], 47, 49 e 50-1). O protagonista está parcialmente vestido em outras seis representações (p. 36 [superior e inferior], 37, 44, 45 e 47), e totalmente vestido apenas na imagem de apresentação do ensaio, na página 35. As fotografias das páginas 42 e 43 foram publicadas em preto e branco, representando a incidência da luz e o reflexo por esta causado na superfície física do corpo do protagonista, exibindo nuances de traços da anatomia deste em contraposição a um fundo negro.

O ensaio foi ambientado em um estúdio de gravação musical, como alusão direta à profissão de Fabinho, vocalista de um grupo de pagode. O uso da imprensa como meio de exposição da imagem junto ao público, descrito por Baeza, bem como a implantação da sociedade do espetáculo de Debord, estão 
presentes nesta seqüência. O sexo é utilizado como linguagem pela exposição do corpo do protagonista, a base sobre a qual se estrutura o discurso da revista nos ensaios. A seqüência de fotografias constrói um sentido lógico baseado nas imagens da anatomia de um corpo masculino, jovem, nu, dentro dos padrões vigentes de beleza e vigor físico. As formas de demonstração desta anatomia masculina refletem uma posição específica para o homem no imaginário do espectador do ensaio, do leitor de G Magazine.

Este discurso, por sua vez, tem um direcionamento bem específico nas páginas do veículo: a exibição explicita do pênis ereto, como característica marcante nos ensaios de $G$ Magazine, faz-se presente em um total de sete fotografias ao longo do ensaio (p. 38, 40-1, 42, 44, 45, 46 [inferior] e 48). 0 ensaio pornográfico - por apresentar o pênis ereto explícito no enquadramento da fotografia - mostra ao leitor o protagonista em sete momentos com o pênis enrijecido, sempre estabelecendo uma reta crescente, como que construindo, da base para a glande, uma linha que sempre aponta para cima, para o alto.

Na quase totalidade destas fotografias, o protagonista olha diretamente para a câmera, para o seu espectador, enquanto exibe seu símbolo maior de masculinidade. Nestes momentos, a captura da liberdade do leitor é exercida pelo protagonista, que cerce aquele de autonomia existencial, dominando-o. 
A linguagem do corpo explanada por Guiraud indica as noções de poder contidas nestas representações. O protagonista demonstra seu poder pela exibição do símbolo de posse deste erguido às alturas, apontando para cima, como o cetro de um rei que legitima sua posição de superioridade hierárquica.

As nádegas do protagonista aparecem em cinco imagens (p. 37 [parcialmente cobertas], 39, 43, 46 [superior] e 47 [parcialmente cobertas]), e em nenhuma destas o modelo estabelece um elo com o leitor por intermédio do olhar. O convite ao leitor para o ato sexual tendo o protagonista como passivo não se estabelece pelo olhar, posto que o cantor naquele momento é representação do masculino, do agente, daquele que detém o poder, legitimado pela posse do 'falo'.

Esta apresentação da parte posterior do corpo pelo protagonista entra, segundo Jacques Aumont (1992), no processo de relação do sujeito com suas identificações formadoras. Refletindo sobre teorias lacanianas, Aumont diz que

"Sólo por mediación de formaciones imaginarias puede efectuarse esta relación: 'figuras del otro imaginario en relaciones de agresión erótica en las que se realizan', es decir los objetos de deseo del sujeto; identificaciones, 'desde la Urbid [imagen primitiva] especular hasta la identificación paterna del ideal del yo' (AUMONT 1992:125).

Aumont ainda menciona que as formações imaginárias do sujeito são imagens, e por intermédio delas este exercerá seu processo de identificação. Ou seja, o 
protagonista dos ensaios fotográficos em $G$ Magazine é objeto de desejo do espectador, o protagonista é modelo, inclusive de identificação do espectador. 0 imaginário deste forma uma imagem idealizada do outro, consumindo-o como objeto de desejo e como ideal do eu.

Assim, as figuras imaginárias do outro produzidas pelo espectador, formadoras da idealização do objeto de desejo deste, somente são possíveis pela mediação estabelecida pelo simbólico, pela linguagem, pela fotografia. Esta identificação obrigatoriamente se dá por intermédio de uma imagem de completude do corpo do outro, o que explicaria a exposição do protagonistas por várias perspectivas.

Mas, mesmo exibindo suas costas para a câmera, o protagonista em geral não se oferece para ser passivo em uma imaginária relação sexual com o espectador, posição que colocaria o exibicionista como objeto a ser manipulado pelo leitor. Sendo este exibicionista representação do masculino, via de regra ele não ocupa a posição objetal passiva no sistema. A estrutura do sistema indicando o masculino como eixo central do poder está mantida no discurso de $G$ Magazine. 


\section{0 poder do masculino.}

A posição do masculino nas fotografias publicadas por $G$ Magazine é fundamental para as reflexões sobre o Imaginário. A exibição do órgão sexual masculino enrijecido, símbolo de demonstração de poder, se faz presente em todos os ensaios publicados pela revista.

Esta posição de atividade do masculino evidencia-se pela freqüente manifestação de poder, enfocando a presença da exibição do pênis ereto como um cetro carregado pelo rei; como o símbolo maior do poder a este masculino conferido pelo coletivo social. A exibição do pênis ereto é um signo embebido numa simbólica construtora de um imaginário que concede ao portador deste cetro a posição de agente, daquele que detém o poder, pois ostenta seu símbolo.

Nas fotografias com o protagonista de costas, este não mantém contato visual com o espectador, como se o modelo o tratasse com indiferença, não depositando neste qualquer atenção e se oferecendo, no máximo, à contemplação, mas nunca anatomicamente a uma relação sexual ocupando a posição passiva.

A rede simbólica construída em torno da posse e exibição orgulhosa do pênis ereto - rede esta consolidada pelos ensaios foto/pornográficos de $G$ Magazine -, como demonstração de poder pertencente ao masculino, mantém imaginariamente nas mãos deste o eixo de decisão. A mulher não possui esta 
capacidade de demonstração física de poder, restando ao feminino um não-lugar na posição de comando no imaginário social, segundo esta linguagem.

No intervalo de abrangência deste estudo, entre janeiro de 2001 e dezembro de 2004, há um desequilíbrio numérico relativo à representação dos protagonistas nas páginas da revista. Ao longo de 48 edições de $G$ Magazine, cada edição contando com dois ensaios fotográficos (mantendo uma média de mais de 20 fotografias por edição), em um número geral que circunda mil fotografias publicadas, observa-se apenas uma imagem que sugere mais explicitamente 0 protagonista em posição de passividade sexual.

Esta imagem 'peculiar' em $G$ Magazine foi publicada na seqüência do chamado 'ensaio interno', não fazendo parte do ensaio de capa. Ou seja, a única fotografia que sugere passividade sexual do protagonista tem como modelo um ilustre desconhecido. Os mais 'famosos', que compõem os ensaios de capa, não aparecem em nenhum momento nos ensaios em posições neste sentido, como que oferecendo seu corpo ao observador para que este aceite um convite a dividir a cena ocupando uma posição de atividade sexual, de acordo com análise das fotografias. 


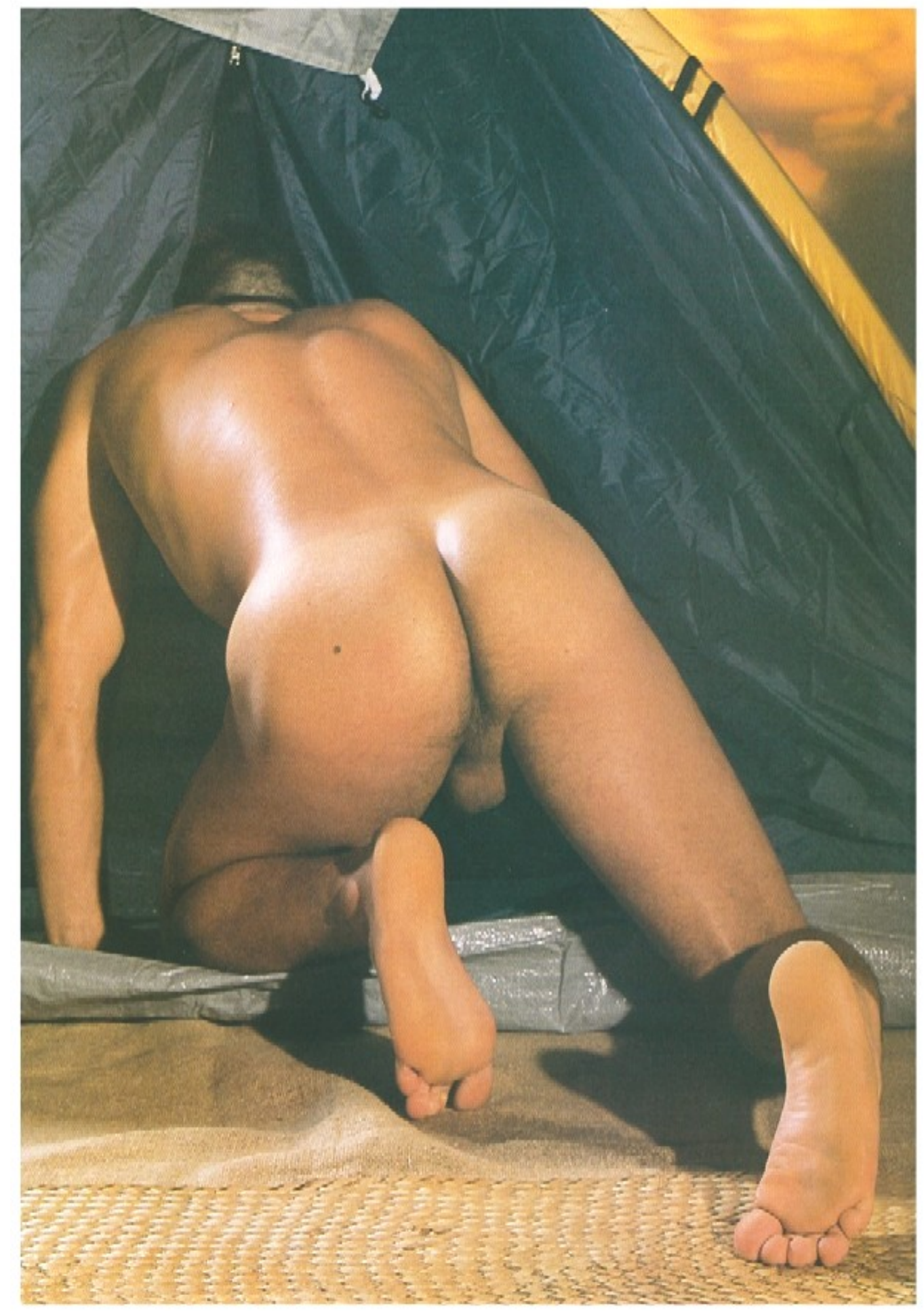

G 77, p. 61

Imagem de protagonista do ensaio em posição de passividade sexual: uma exceção às seqüências características da revista que, de forma geral, legitimam a posição ativa do masculino - o possuidor do pênis e, portanto, do poder - na sociedade. 
A demonstração de poder físico pela posse e exibição do pênis enrijecido, 0 cetro do rei ou 'falo', é uma base de sustentação da masculinidade. A imagem reproduzida da edição 77 de $G$ Magazine causa uma inversão do papel hegemônico do masculino, por representar o corpo-signo do protagonista do ensaio numa disposição anatômica que vai de encontro às idéias de dureza e de verticalidade erguida, que de acordo com Guiraud sustentam noções de virilidade as quais ostentam aqueles que exibem um pênis ereto.

A imagem do protagonista literalmente "de quatro" (com o corpo-signo prostrado à frente, apoiado pelas mãos e joelhos) não reflete o direcionamento de ostentação e exibição de poder por parte do masculino. Este corpo-signo prostrado omite o símbolo maior de masculinidade, o pênis, e dispõe fisicamente o corpo do homem de uma forma que o deixa exposto ao exercício do domínio por parte de outro.

A posição corporal representada naquela fotografia traz consigo noções de curvado, mole e baixo, as quais Guiraud opõe às disposições físicas de demonstração de posse do poder, causando uma 'apassivação' do masculino, papel inverso ao tradicionalmente ocupado por este no sistema. Esta representação é uma exceção à linguagem utilizada por G Magazine para organizar o seu discurso. 
Em imagens com exibição do pênis ereto, o lugar-comum nas seqüências fotográficas de G Magazine, quando há o olhar lançado pelo protagonista sobre o espectador, aquele sugere um convite à passividade deste último.

Com relação ao olhar, o filósofo francês Jean-Paul Sartre (2005) menciona uma espécie de impasse intersubjetivo: especialmente nas relações amorosas, o amante quer ser o olhar no qual a liberdade do outro aceita se perder, olhar sob o qual o outro se aceita transformado em objeto. Este processo ocorre sob a atuação da libido, força-motriz da pulsão sexual. Sartre enfatiza que "identifico-me totalmente a meu ser-olhado a fim de manter diante de mim a liberdade 'olhante' do outro; é apenas este ser-objeto que pode servir-me de instrumento para operar a assimilação, a mim, da outra liberdade" (SARTRE 2005:404). Assim, o filósofo institui uma hierarquia no olhar: o sujeito que olha - especialmente num contexto amoroso - reifica o outro para que este, no seu olhar, aceite amorosamente ser feito objeto, perdendo-se neste olhar.

Este tom inebriante do olhar para Sartre será marcante em G Magazine: na maioria das fotos há o olhar do protagonista diretamente para a câmera, para o espectador. Os modelos dos ensaios exibem seus corpos e, em vários momentos, olham fixamente para o leitor, procurando torná-lo objeto e fazer com que este libidinosamente se perca, abra mão de sua liberdade existencialista e torne-se objeto. Uma vez nesta posição, o leitor subjuga-se ao olhar do protagonista, 
sucumbe a este e passa a ocupar a posição do manipulado, do controlado, daquele que somente é em razão do desejo de quem olha.

Assim, estabelece-se uma relação de poder em que aquele que olha tem o controle, e aquele olhado, que se perde no olhar, tem a sua liberdade aprisionada e coloca-se à disposição do domínio de quem olha. O corpo-signo do protagonista que lança o olhar está fisicamente disposto - via de regra - de forma a ocupar uma posição de atividade sexual por parte deste, que exibe seu pênis ereto e o oferece ao leitor. Este leitor, por sua vez, aprisionado no olhar convidativo lançado pelo protagonista, é levado cativo imaginariamente a ocupar a posição de passividade no estabelecimento da relação entre eles. 




G 68 , p. 37

Imagem do ensaio de capa da edição 68, estabelecendo especialmente através do olhar uma cumplicidade com o espectador: um convite a desfrutar do que suas mãos oferecem; o protagonista ocuparia, no imaginário da ação sexual, a posição ativa. 
Mas, esta mesma cumplicidade do olhar não se estabelece inversamente, quando o fotografado é focado de costas para a câmera, ou em qualquer posição que não denote sua atividade no ato sexual pela demonstração de poder do seu pênis.

Esta indicação generalizada, de ostentação e demonstração de poder do masculino, por intermédio da exibição do símbolo deste poder e pelo controle exercido pelo olhar, é traço explícito na linguagem mais largamente utilizada na representação dos corpos-signos por parte da revista. Estes caracteres ditam o direcionamento da mensagem que $G$ Magazine passa a seus leitores, construindo o discurso do veículo ao longo dos ensaios fotográficos.

Além dos aspectos já citados, ainda há outros traços identificadores que norteiam a interpretação imaginária dos corpos-signos. A jornalista Ana Maria Fadigas, diretora responsável de G Magazine, declarou para este trabalho que existe um certo parâmetro a ser seguido pela revista, que ela preferiu chamar de núcleo: um perfil étnico-etário dominante ou preferido do público-alvo. São homens jovens, brancos, olhos e/ou cabelos claros e fisicamente robustos. São os estabelecidos deste meio outsider.

"Se eu sair do 'núcleo', sou queimada em praça pública", afirma Ana Maria quando perguntada sobre a presença de protagonistas de etnias variadas na capa. 
O núcleo, segundo levantamento deste trabalho, inclui homens cuja pele possui coloração branca, preferencialmente com cabelos e/ou olhos claros (em tons de azul, verde ou mel), idade inferior a 30 anos e corpo atlético ostentando uma anatomia com músculos delineados pelos exercícios físicos. Guardando-se os devidos referenciais, este 'núcleo' mencionado pela jornalista ocuparia a posição estabelecida no sistema gay, tornando outsiders aqueles que não possuem tais atributos. A aplicação de estudos antropológicos sobre estes dados poderia concluir muito a respeito do funcionamento das relações dentro da comunidade gay.

Este indicativo de direcionamento perpassa o processo de interpretação das imagens fotográficas, processo este que necessariamente passa pela atuação do imaginário do leitor, que posicionará simbolicamente o corpo-signo. Desta forma, uma convergência entre campos de estudo sobre a linguagem, em especial a da imagem e da fotografia, bem como processos psíquicos que envolvem a interpretação de um signo por um sujeito faz-se mister neste momento do trabalho. 
CAPÍTULO IV

DAS CATEGORIAS E DOS REGISTROS 


\section{As convergências entre Peirce e Lacan}

Em continuidade, utilizaremos uma aproximação de dois campos importantes para este estudo: o semiótico e o psicanalítico. A possibilidade de tal paralelo foi apresentada em um texto de Lucia Santaella (1999) intitulado As três categorias peirceanas e os três registros lacanianos. Neste artigo, a autora propõe uma comparação geral entre as categorias fenomenológicas universais de Charles Sanders Peirce (primeiridade, secundidade e terceiridade), de um lado, e as três categorias conceituais da realidade humana de Jacques Lacan (Imaginário, Real e Simbólico), de outro.

Santaella faz uma análise comparativa entre Peirce e Lacan, salientando que a lógica da terceira categoria peirceana, que é a lógica do signo, pode funcionar como direcionamento para a compreensão das interações complexas que os registros lacanianos mantêm entre si. Esta proposta de aproximação dos dois campos científicos enriquecerá nossas conclusões sobre os corpos-signos utilizados por G Magazine.

Ao considerar a fotografia como signo, estamos incluindo esta representação como forma de linguagem, um sistema de signos constituído por características específicas que regem sua representação. Partindo da reflexão de teóricos sobre o tema - como Roland Barthes e Arlindo Machado - e aplicando suas conclusões às seqüências que compõem os ensaios fotográficos de $G$ 
Magazine, identificamos neste trabalho o teor pornográfico do conteúdo das imagens constantes nas páginas do veículo.

A interpretação do signo, ou seja, carregá-lo de significação e posicioná-lo na rede simbólica de representações, depende diretamente da interação do sujeito para com este signo. Em se tratando dos corpos-signos de $G$ Magazine, representados em ensaios foto/pornográficos, o posicionamento desta representação dependerá de aspectos ligados à sexualidade do indivíduo-leitor, a como a pulsão sexual nele atuante reage à simbólica do nu pornográfico masculino, produzindo no seu imaginário uma interpretação.

Desta forma, a interação entre as tricotomias fenomenológica de Peirce e psicanalítica de Lacan, proposta por Santaella, é de suma importância para a conclusão deste trabalho. A foto/pornografia publicada por G Magazine é signo que segue a lógica da terceira categoria peirceana, encontrando, assim, um diálogo com os registros lacanianos, fato que auxiliará a obtenção do êxito das aspirações deste estudo.

A fenomenologia, de forma geral, constitui-se de formulações teóricas que buscam ressalvar descritivamente a experiência vivida da subjetividade, em detrimento de princípios, teorias ou valores preestabelecidos. Tais formulações estão especialmente ligadas às Ciências Humanas, Psicologia ou Psicanálise. 
Segundo Santaella, Charles Sanders Peirce levou 30 anos para completar sua teoria das categorias fenomenológicas, dividindo-a em três bases fundamentais. Esta divisão triádica é um ponto de partida importante para a análise de qualquer fenômeno.

Lucia Santaella explica brevemente as categorias fenomenológicas peirceanas, enfatizando que

"a categoria da primeiridade inclui as idéias de acaso, originalidade, espontaneidade, possibilidade, incerteza, imediaticidade, presentidade, qualidade $e$ sentimento. Na secundidade, encontramos idéias relacionadas com polaridade, tais como força bruta, ação e reação, esforço e resistência, dependência, conflito, surpresa. Terceiridade está ligada às idéias de generalidade, continuidade, lei, crescimento, evolução, representação e mediação" (SANTAELLA 1999:84).

Por serem apenas noções gerais que indicam o perfil lógico dentro do qual algumas classes de idéias se incluem, as categorias universais não substituem nem excluem a variedade de outras categorias que podem ser encontradas em todos os fenômenos.

Para Peirce, a fenomenologia é ponto de partida para a análise de um fenômeno qualquer, mas as ferramentas analíticas vêm dos conceitos semióticos. 
A decodificação de signos, paralelamente, passa por três estágios, ou categorias do pensamento: índice (primeiridade - signo que denota o referente baseado na conexão física entre ambos), ícone (secundidade - signo que denota o referente simplesmente em virtude das características que ele possui, quer esse referente exista realmente, quer não) e símbolo (terceiridade - signo que denota seu referente em virtude de uma lei, associação de idéias, convenção) (SANTAELLA 2003b).

Assim, temos um paralelo estabelecido com relação ao nascimento da Semiótica dentro da Fenomenologia:

$\begin{array}{lll}\text { FENOMENOLOGIA } & \rightarrow & \text { SEMIÓTICA } \\ \text { PRIMEIRIDADE } & \rightarrow & \text { ÍNDICE } \\ \text { SECUNDIDADE } & \rightarrow & \text { ÍCONE } \\ \text { TERCEIRIDADE } & \rightarrow & \text { SÍMBOLO }\end{array}$

Para Santaella, "a semiótica nasce no coração da fenomenologia", já que a lógica da terceira categoria fenomenológica corresponde à noção de signo, "ela é o signo" (SANTAELLA 1999:89). Assim, o signo como representação simbólica estaria situado na categoria universal fenomenológica da terceiridade.

Em seu artigo, após traçar a aproximação entre fenomenologia e semiótica peirceanas, Santaella salienta que

"dada a generalidade lógica dessas categorias, entretanto, elas não são capazes de especificar o 
conteúdo desses registros, pois essa especificação só pode vir do campo da psicanálise. Conseqüentemente, a fenomenologia e a semiótica só podem fornecer o substrato lógico, sem poder indicar quais são as características específicas que a primeiridade, secundidade e terceiridade adquirem na psicanálise" (Idem).

Com o auxilio de conceitos psicanalíticos, as categorias fenomenológicas adquirem características especificas que auxiliam a apontar o conteúdo dos fenômenos por ela registrados. Lucia Santaella, a partir deste ponto, estabelece um paralelo entre as categorias fenomenológicas e os registros psicanalíticos. "Assim, primeiridade, secundidade e terceiridade podem ser proeminentemente percebidas no imaginário, real e simbólico respectivamente" (Idem, p. 87).

Temos, portanto, um segundo paralelo:

FENOMENOLOGIA

PRIMEIRIDADE

SECUNDIDADE

TERCEIRIDADE

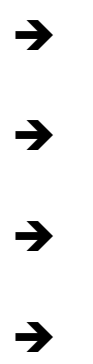

PSICANÁLISE

IMAGINÁRIO

REAL

SIMBÓLICO

Esta aproximação proposta por Santaella vem ao encontro do presente estudo. As fotografias de $G$ Magazine são signos - ou corpos-signos, como os temos chamado. Então, lidamos com processos semióticos de significação, já que 
estamos tratando de representação. O teor destas imagens é pornográfico, atiçando a atuação da libido que leva o sujeito à busca pelo suprimento da demanda criada pela pulsão sexual, ações de ordem psíquica. Assim sendo, o processo fenomenológico da subjetividade na interpretação imaginária destes corpos-signos por parte do sujeito depende diretamente do desencadeamento de aspectos psíquicos ligados à sexualidade.

Um quadro mais completo da proposta de Santaella seria como segue:

$\begin{array}{lllll}\text { PSICANÁLISE } & \leftarrow & \text { FENOMENOLOGIA } & \rightarrow & \text { SEMIÓTICA } \\ \text { IMAGINÁRIO } & \leftarrow & \text { PRIMEIRIDADE } & \rightarrow & \text { ÍNDICE } \\ \text { REAL } & \leftarrow & \text { SECUNDIDADE } & \rightarrow & \text { ÍCONE } \\ \text { SIMBÓLICO } & \leftarrow & \text { TERCEIRIDADE } & \rightarrow & \text { SÍMBOLO }\end{array}$

Como próximos passos, analisaremos estes paralelos entre as categorias semióticas e os registros psicanalíticos. 


\title{
O símbolo semiótico e o registro simbólico.
}

Sabendo-se que 'a semiótica nasce na fenomenologia', sobre este paralelo pode-se construir a seguinte estrutura: pela ligação de ambos com a categoria fenomenológica da primeiridade, o índice semiótico é da ordem psíquica do Imaginário; partindo da secundidade, o ícone semiótico é da ordem do Real; e o símbolo semiótico, da ordem do Simbólico a partir da terceiridade.

O símbolo semiótico, nascido na terceiridade fenomenológica, é signo que representa seu referente em virtude de uma lei, associação de idéias ou convenção. Segundo Santaella,

\begin{abstract}
"Terceiridade está ligada às idéias de generalidade, continuidade, lei, crescimento, evolução, representação e mediação. (...) A correspondência do registro simbólico com a terceiridade é óbvia. $O$ grande Outro em todos os seus sentidos é sempre terceiridade. É lei, mediação, estrutura regulada que prescreve o sujeito" (Idem, p. 83, 87).
\end{abstract}

O registro do Simbólico é o lugar do código fundamental da linguagem, regido por leis específicas. A terceira categoria corresponde exatamente à noção de signo, dadas as qualidades da terceiridade de representação e mediação, papéis exercidos pela linguagem por intermédio do signo, elo de ligação entre um interpretante e um objeto. 
O símbolo semiótico, dada a ligação que estabelece entre o signo e seu referente ter como base a associação convencional de idéias, nasce na categoria fenomenológica da terceiridade e, portanto, tem relação direta com a instância psíquica do Simbólico. É a partir desta instância que o sujeito tenta organizar o caos de tudo que o rodeia, procurando montar uma teia ou rede que interligaria e estruturaria todas as idéias. Estas idéias teriam representações, ou signos, que passariam a ocupar um lugar específico e desempenhar um papel definido, para que o caos torne-se minimamente organizado. Nasce, desta forma, uma linguagem construída sobre uma cadeia de significantes. A partir do domínio da linguagem, o sujeito psíquico passa a existir.

Desta forma, a 'construção' de uma determinada realidade para um sujeito depende da forma como este posicionará os signos que o cercam na rede simbólica, o que servirá de matriz para uma interpretação do mundo. Conseqüentemente, a escolha dos signos que representarão uma realidade influencia diretamente nesta visão de mundo que o sujeito construirá. Os signos, formadores da linguagem, são os mediadores entre o sujeito e o referente, e determinar os signos utilizados para passar uma mensagem é ferramenta importante para moldar uma idéia a ser disseminada. 
Assim, a mediação que a fotografia em $G$ Magazine estabelece entre o sujeito-leitor e o corpo nela representado é de ordem simbólica. O corpo-signo é a principal linguagem utilizada pela revista para estruturar o seu discurso. Em $G$ Magazine o corpo masculino nu representado na fotografia é corpo-signo anatomicamente exibido de forma a simbolizar uma idéia e passá-la como mensagem, estruturando o discurso da revista.

Conforme vimos, a fotografia em $G$ Magazine representa corpos masculinos nus fisicamente dispostos tendo como foco a exibição explícita do pênis ereto. Segundo Guiraud (1991), tal disposição física tem relação com as idéias de direção, de posse e ostentação de poder, referenciando o masculino como detentor do controle. Esta é a base sobre a qual se estrutura o discurso da revista. O masculino em posições de demonstração de poder é o signo - ou corpo-signo escolhido pela revista para posicionar sua idéia no sistema.

Baseados em Foucault, podemos identificar nas seqüências fotográficas publicadas pelo veículo um discurso do sexo embasado numa linguagem corporal que posiciona simbolicamente o masculino no sistema, tendo como reflexo no imaginário social a identificação da posição, ou do papel deste masculino no sistema, gerando um discurso de controle baseado na sexualidade. 


\section{0 índice semiótico e o registro imaginário.}

A escolha do signo que estabelece a mediação entre o sujeito e o mundo influencia diretamente a construção mental que o indivíduo elaborará de uma dada realidade. A mediação é de ordem simbólica, e dá luz a uma interpretação imaginária por intermédio de processos de identificação do signo para com o seu referente.

O índice semiótico, nascido na primeiridade fenomenológica, é signo que representa seu referente pelo estabelecimento de uma conexão física entre ambos. Esta conexão física desencadeia o processo de identificação. Para Santaella, qualquer processo de identificação é de ordem imaginária, pois identificar é

"obliterar a distinção entre o sujeito e o objeto da identificação, como um estado monádico que almeja a completude e sempre à beira da dissipação, pois um dos pólos desta pretensa unidade está sempre à beira do desaparecimento. (...) Tal iminência de dissipação é uma das principais características da primeiridade", (Idem, p. 86).

O processo de identificação procura a correspondência entre o referente e o signo que o representa pelos indícios apresentados que possam conectá-los. 0 modelo do Imaginário é a imagem do corpo, uma imagem ilusória de inteireza. Com esta base, toda interpretação imaginária alude à criação de uma totalidade 
perfeita, ignorando diferenças reais. Por intermédio desta instância o sujeito 'filtra' o mundo, construindo uma interpretação ilusória deste por inteiro. O grau de inteireza é tão profundo que o mundo parece duplicado, porém, sua réplica imaginária é ideal: o mundo é um sistema e funciona como tal.

No caso das fotografias de $G$ Magazine, tal conexão física do signo com o referente se dá pelo reconhecimento da imagem de uma pessoa representada naquela fotografia. Porém, este reconhecimento criará uma interpretação ilusória, imaginária. O corpo-signo ocupa o lugar do protagonista fotografado no momento da leitura da imagem, e por intermédio da identificação oblitera-se a distinção entre o sujeito e o objeto da identificação. Aumont (1992) menciona o processo de identificação entre o espectador e a imagem do outro que ele observa. Mas, esta identificação pela imagem do corpo dá-se com tons de inteireza, de idealização do corpo.

Tal identificação é extremamente frágil, prestes a deixar de existir, já que se estrutura sobre uma representação de natureza ideal e completa, que só é possível na instância psíquica do Imaginário, dada a visão de inteireza do corpo do protagonista. A idealização é passível de quebra iminente, especialmente pela atuação circular da tricotomia psíquica de Lacan: o abrupto Real ou o mediador Simbólico podem atuar, fazendo com que esta interpretação imaginária do leitor esteja à beira da dissipação a qualquer momento. 
Este fundamento de identidade é que permite ao signo que ele funcione como tal. Os indícios que a representação fotográfica exibe na revista constroem uma realidade psíquica ao observador do corpo-signo, uma forma de este enxergar e interpretar aquele momento, posicionando simbolicamente a imagem como forma de linguagem. A fotografia como índice semiótico, então, pertenceria à instância do Imaginário.

Tendo em vista que, para a identificação são utilizadas conexões físicas do signo com o seu referente, o leitor interpreta imaginariamente aquela reprodução fotográfica como a imagem do protagonista do ensaio de G Magazine e vê um corpo idealizado, fazendo uma interpretação e impondo sobre a imagem uma visão parcial, idealizada.

A linguagem utilizada para apresentar esta 'dada realidade', moldada na instância do Simbólico pelo manuseio do corpo-signo, influencia diretamente na estrutura ilusória construída imaginariamente pelo leitor. As noções de posse e demonstração de poder intrínsecas à disposição anatômica do corpo, bem como à exibição explícita do pênis ereto pelo protagonista dos ensaios de G Magazine, direcionam a visão imaginária do mundo. O masculino é o possuidor legítimo de um status hierarquicamente superior no sistema, pois seu corpo apresenta indícios diretamente ligados a noções divinas de manifestação e ostentação de poder. 
$\mathrm{Na}$ instituição imaginária da sociedade, explicada por Castoriadis, o homem ocupa 'naturalmente' a posição central do eixo sobre o qual gira o sistema. Esta visão é facilmente identificável na constante manifestação corpóreo-sígnica que constrói o discurso de G Magazine, e este é o cerne significante que direciona a leitura da linguagem publicada pela revista. Em uma sociedade patriarcal, tal discurso androcêntrico, mesmo estruturado sobre uma linguagem não-usual, vai ao encontro da cultura imaginariamente construída e legitimada no mundo ocidental. 


\section{O ícone semiótico e o registro do Real.}

Avançando sobre o paralelo proposto por Santaella, a fotografia como ícone corresponderia à instância do Real. O ícone semiótico, por um processo de aproximação, é signo que apresenta as características gerais do referente. 0 referente torna-se, portanto, algo aproximado, porém não capturado, tendo em vista que o Real não pode ser simbolizado.

"O real é aquilo que sobra como resto do imaginário e que o simbólico é incapaz de capturar. O real é o impossível, aquilo que não pode ser simbolizado. (...) Esta polaridade, esta fratura entre o imaginário e o real, entre o simbólico e o real corresponde exatamente à categoria da secundidade. O real é sempre bruto e abrupto. É causação não governada pela lei do conceito" (Ibidem).

O ícone semiótico não é o mesmo que uma imagem mental que representa um objeto. No caso da imagem mental, ter-se-ia de abstrair, dentre muitas imagens particulares, uma geral. Lacan reconheceu que, para o falante, há inadequação na relação entre o objeto e sua imagem, entre as partes do corpo e a imagem que se tem dele, por exemplo.

O ícone peirceano é o fenômeno que funda cada possível juízo de semelhança, pelas características do objeto e aproximação deste com o signo. Dessa forma, pode-se inferir que o ícone corresponderia ao fenômeno sob o qual é possível construir uma representação do objeto, sendo, portanto, a base sob a 
qual o fenômeno é percebido. Assim, evidencia-se que o ícone configura-se em elemento fundamental ao processo de percepção, representando o suporte sobre o qual ocorre tal processo. Em suma, ele é a razão do signo.

Segundo Dubois, a fotografia não concede ao seu espectador qualquer significação relativa ao referente nela imagetizado, centrando seu foco na simples apresentação da existência (em um ponto qualquer do espaço/tempo) daquela imagem (DUBOIS 2004:84). Assim, a fotografia foca no objeto, na ação de um fato qualquer no seu 'aqui/agora', no seu puro acontecer, no ato de acontecer, enfatizando o fato em si mesmo e desconsiderando qualquer causalidade ou lei que pudessem tê-lo determinado. Desta forma, o foco na apresentação pura e simples do objeto posiciona a fotografia na categoria fenomenológica da secundidade, que enfatiza as relações de ação e reação, de polaridade bruta e que, segundo Santaella, pode ser percebida na instância psicanalítica do Real, sem representação significativa deste objeto fotografado, apenas sua apresentação.

É necessário um nível mais alto de abstração para que, sobre uma base icônica de semelhança, possamos representar simbolicamente uma idéia qualquer, e desta construirmos uma leitura imaginária. 
A semelhança de um objeto é definida pelo grau de adequação deste com um segmento constitutivo do objeto real, numa relação que é estabelecida pelo campo perceptivo. Desse modo, a semiótica se introduziria neste foco de estudo do ícone, no qual a semelhança se manifesta enquanto a maneira por meio da qual o sujeito conhece e, posteriormente, ressignifica o mundo.

Esta ressignificação já não mais pertence à instância do Real e, portanto, o signo não se tratará mais de ícone semiótico, pois a busca pela identificação é de ordem imaginária, enquadrando-se, assim, como índice semiótico. O Real corresponde ao objeto a ser representado em outra instância, o Real é aquilo que determina o signo e, ao mesmo tempo, é representado por ele a partir do momento em que este objeto corresponde simbolicamente a um nó no imaginário.

Em linhas gerais, a fotografia de $G$ Magazine exerce esta relação indissociável de um fundamento imaginário de identificação daquela representação com um corpo que, por sua vez, era real, pois determina o signo e é por ele representado simbolicamente, surtindo o efeito de representação imaginária para o leitor. Daí a importância desta aproximação proposta por Lucia Santaella para o desenvolvimento deste trabalho.

Para finalizar, Santaella explica a lógica triádica do signo da seguinte forma, levando em consideração o fundamento (o processo de identificação), o objeto 
(aquilo que o signo representa em outra instância) e o interpretante (processo de representação por meio da linguagem):

"O imaginário, isto é, a categoria da demanda do amor, ocupa a posição lógica do fundamento do signo. O real, a categoria da pulsão sexual, ocupa a posição lógica do objeto do signo, enquanto o simbólico, a categoria do desejo, ocupa a posição lógica do interpretante" (Idem, p. 89).

Para Peirce, o signo é uma relação indissociável entre um fundamento (Imaginário), que permite ao signo funcionar como tal; um objeto (Real), que determina o signo; e um interpretante (Simbólico), o efeito que o signo pode produzir em uma mente interpretadora qualquer.

No que diz respeito a este trabalho, a correlação entre estes três complexos campos do conhecimento humano dá-se na perspectiva de identificar o discurso de um veículo de comunicação que se utiliza da linguagem de corpos-signos embebidos em teor pornográfico. Pelo teor pornográfico do material, aspectos psíquicos da sexualidade tornam-se fundamentais para melhor compreensão dos caminhos utilizados para $G$ Magazine atingir seu objetivo de comunicação por intermédio desta linguagem peculiar: o corpo masculino em nu explícito, frontal e com ereção. 
A imagem do corpo-signo publicada nas páginas da revista é representação por excelência. Este corpo é um signo que pretende penetrar no Imaginário do leitor e obter como resultado o suprimento de uma demanda: fazer-se ilusoriamente inteiro e proporcionar ao espectador a manifestação de um prazer proibido. O corpo masculino nu assume significados concedidos por disposições anatômicas dos modelos durante os ensaios, e tal anatomia direciona ao entendimento de que estes modelos, como possuidores do falo, são os legítimos representantes do poder estabelecido no sistema social vigente. Eles são masculinos, e ao homem caberia - pela imaginária posse e demonstração do poder do falo - a posição central do eixo de decisões.

A exibição do pênis ereto sendo oferecido explicitamente ao espectador coloca o protagonista do ensaio em posição de atividade sexual e como o detentor do poder, posto que este poder está representado pelo órgão sexual, imaginariamente confundido com o falo que a todos falta.

Concernente a isso, o discurso da sexualidade de G Magazine torna-se ainda mais persuasivo quando temos uma cultura que se direciona para uma mudança importante de comportamento. A demonstração dos prazeres proibidos na sociedade contemporânea está sofrendo uma metamorfose profunda, segundo análise do psicanalista Charles Melman, na sua forma de encarar o gozo. 


\section{Um gozo no Real.}

Quando o termo 'gozo' é empregado psicanaliticamente, não se deve entendê-lo em sua acepção corriqueira, mesmo que haja uma associação entre ambas. Comumente, gozar remete ao gozo sexual e, por isso, tem parcialmente uma ligação com o prazer. Mas, simultaneamente, o gozo está além do prazer. Lacan (1992a) indica que o prazer é uma forma de se proteger do gozo, e Freud indica a existência de um além do princípio do prazer.

Assim, degustar uma boa bebida pode ser um prazer, mas o alcoolismo transporta o sujeito para um gozo do qual ele se vê escravo. Este mesmo gozo pode ser encarado como o funcionamento de um sujeito que repete um comportamento sem saber o que o obriga a assim permanecer, mas que the confere uma satisfação temporária.

O gozo é de ordem simbólica, já que o próprio Lacan, no seminário $O$ avesso da psicanálise, estabeleceu que "natural ou não, é efetivamente como ligado à própria origem da entrada em ação do significante que se pode falar de gozo" (LACAN 1992b:168), colocando a gênese do gozo na ação do significante, ou seja, na linguagem, no território simbólico.

Importante, conforme já analisado, que a disposição física do objeto - o corpo-signo - na seqüência dos ensaios fotográficos de G Magazine direciona o 
interlocutor a uma leitura de certos indícios constantes das imagens, que o levam a posicionar simbolicamente o objeto fotografado na cadeia de significantes, fazendo com que este ocupe um lugar específico no imaginário.

Mas, no que é chamado por algumas linhas de pensamento de período da pós-modernidade, esta estrutura do gozo explanada por Lacan parece sofrer alguma alteração. Charles Melman sugere um homem atual que seguiria a cartilha do que chama de 'nova economia psíquica'. Para Melman, "a nova economia psíquica privilegia o gozo do objeto em detrimento do gozo fálico" (MELMAN 2003:142), retirando, desta forma, o gozo da instância simbólica (da representação, do Falo), posicionando-o no objeto, no ícone da instância do Real.

O psicanalista continua sua análise, explicando que nesta nova estrutura "estamos lidando com uma mutação que nos faz passar de uma economia organizada pelo recalque a uma economia organizada pela exibição do gozo. Não é mais possível hoje abrir uma revista, admirar personagens ou heróis de nossa sociedade sem que eles estejam marcados pelo estado específico de uma exibição do gozo" (Idem, p. 16).

A práxis do comportamento deste homem pós-moderno, fragmentado em sua existência, de forma geral passa de uma organização sobre recalcadas regras religiosas de cunho moral a uma outra, estruturada numa exibição do gozo. A 
manifestação daqueles prazeres classificados por Freud como proibidos está perdendo seu grau de interdição, segundo direcionamento dado por Melman. 0 recalque está cedendo lugar à exibição, e a sociedade contemporânea parece direcionar-se a um nível de permissividade da experiência e, mais ainda, à exibição pública deste gozo.

Tornou-se lugar-comum o 'estado específico de uma exibição do gozo', especialmente por meio da mídia. Assim, utilizar-se do discurso do sexo como ferramenta de persuasão toma tons mais imperativos, mais explícitos, tendo em vista este enfraquecimento do recalque, da lei que proíbe a demonstração de determinados prazeres.

De acordo com Melman, na nossa sociedade

"é bem evidente que cada um pode publicamente
satisfazer todas as suas paixões e, além do mais,
pedir que elas sejam socialmente reconhecidas,
aceitas, até legalizadas. (...) Estamos no exato ponto
do abandono de uma cultura, ligada à religião, que
obriga os sujeitos ao recalque dos desejos e à
neurose, para nos dirigir a uma outra em que se
propagandeia o direito à expressão" (Idem, p. 29,
107).

Esta nova economia configura-se numa prova evidente de exibição do gozo, talvez disfarçada sob a acepção do que é comumente chamado de liberdade de 
expressão', difundida pelo discurso burguês pós-Revolução Francesa e concedida principalmente pela queda do poder do recalque religioso no Ocidente. Esse processo levaria a civilização contemporânea a seguir um caminho de busca - livre e legitimada - de manifestação do gozo, uma forma de exposição da intimidade, já não tão 'íntima'. Assim, como sugere o subtítulo do livro de Charles Melman, este processo levaria o homem à procura de um gozar a qualquer preço.

O direito propagado por esta nova economia psíquica à livre expressão e plena satisfação dos desejos inclui, logicamente, o campo da sexualidade, um dos pontos centrais de atuação do recalque moral religioso. Melman deixa claro que "a nova economia psíquica faz dele [o sexo] uma mercadoria entre outras" (Idem, p. 48). Nesta ordem, o sexo é produto a ser manipulado na troca de valores do mercado, visando à busca do gozo e sua exibição.

Importante salientar que, em se tratando de uma economia psíquica, o sexo é mercadoria de alto valor nas trocas imaginárias, ou seja, não estamos lidando aqui com o corpo como mercadoria de troca física, mas com o corpo-signo como mercadoria de troca imaginária. G Magazine utiliza-se desta importante faceta da nova economia psíquica para estruturar seu discurso sobre uma linguagem que utiliza o sexo como mercadoria de troca imaginária.

Neste sentido, Melman define: 
"Em outras palavras, trata-se de exibir permanentemente o que ordinariamente se encontra mascarado, reservado, por exemplo, no momento da efusão amorosa, e de fazer de forma a que, de cara, o interlocutor seja convidado ao gozo explícito, partilhado, desse objeto. Ora, parece que se tornou, nos dias de hoje, um, até mesmo o comportamento comum. Esse dispositivo participa do que alimenta a economia do mercado, quer dizer, a constituição de comunidades que se agrupam em torno do mesmo objeto explícito de satisfação" (Idem, p. 52).

Neste momento, falando especificamente da 'economia do mercado', Melman avalia que a exibição pública do que um dia foi considerado privado configura-se num convite explícito ao gozo, segmentando a sociedade em grupos de indivíduos que partilhariam de um mesmo objeto de satisfação. A manifestação de prazeres, outrora mais proibidos que hoje, tem seu reflexo na economia do mercado pela criação do que o autor chama de 'comunidades' que processam tal manifestação e se satisfazem em torno do mesmo objeto. As noções de fronteira entre o público e o privado no que se refere ao obsceno tornam-se tênues.

Assim, pela 'exibição permanente' do objeto que imaginariamente supre a demanda criada pela pressão orgânica leva o sujeito ao gozo. Para Melman, este seria o comportamento mais corriqueiro do homem fragmentado da pósmodernidade. 
A criação de uma espécie de nicho em torno de um mesmo objeto explícito de satisfação contribui para um aumento da estigmatização entre os grupos - ou comunidades, como sugeriu Melman - na sociedade atual: sujeitos com gozos específicos constroem verdadeiras irmandades para partilha em torno do suprimento de uma demanda peculiar, grifando ainda mais o teor fragmentado do mosaico social da contemporaneidade. No caso dos leitores de G Magazine, a exibição do gozo dá-se por intermédio da contemplação do sexo inscrito no corpo do protagonista e explicitamente exibido nas imagens que compõem os ensaios fotográficos da revista. Esta contemplação reflete no desencadeamento de uma interpretação imaginária na mente do leitor, que momentaneamente supre sua demanda.

Tal contemplação, nesta nova economia psíquica, tem uma qualidade peculiar. A fotografia pornográfica permite "um acesso mais direto ao objeto real, quer dizer, ao pênis", configurando-se numa "exibição permanente do objeto explícito de satisfação" (Idem, p. 52). Neste sistema, "o que o objeto é vale mais do que representa" (Idem, p. 55). Assim, a apresentação pornográfica do sexo - e não o que ele representa - exerce um importante papel no eixo principal de interpretação da mensagem em G Magazine. 
É como se a terceiridade fenomenológica fosse deixada de lado, e o símbolo semiótico perdesse em muito seu valor, pois as noções de representação não mais teriam um papel a cumprir. O que o objeto (secundidade) sugere em uma mente (primeiridade), sem mediações, direcionaria o sujeito ao gozo do objeto, e não do que ele representa.

Este foco no objeto apresentado, e não em uma representação dele, aproxima o corpo-signo estampado na fotografia pornográfica da categoria fenomenológica da secundidade (do bruto e abrupto, do instantâneo, da reação, do surpreendente, sem mediações) e, portanto, da instância lacaniana do Real, pois nestes casos a fotografia não representaria, mas apresentaria o objeto explícito de gozo a ser partilhado pelos interlocutores. A presentação do protagonista (exibindo-o como se não houvesse a mediação simbólica da linguagem, ou seja, como que o fazendo presente ao espectador) exibindo explicitamente o pênis em ereção é a manifestação do objeto de satisfação, que convida o leitor ao gozo explícito, e este gozo não necessita de uma representação do objeto, mas da simples presentação deste ao sujeito.

Como estamos num sistema no qual 'o que o objeto é vale mais do que o que representa', exibir explicitamente este objeto à partilha do gozo, sem leis mediadoras, sem representações simbólicas, concede ao ser mais valia que o simplesmente representar. Nas fotografias de G Magazine o corpo-signo - com 
foco especial no pênis ereto - é presentado ao leitor sem regras convencionais que impeçam o livre acesso deste à visão do objeto: o convite ao gozo não é dado a entender, ele simplesmente se faz.

Este convite direto, abrupto, impactante, causa no imaginário do leitor uma interpretação ilusória de momentânea cumplicidade, até mesmo de intimidade com o protagonista, que prende o sujeito na contemplação de sua demonstração fálica de poder. Estabelece-se, assim, a perda da liberdade do sujeito-leitor, capturado pela imagem, inebriado pela sua interpretação, satisfazendo sua demanda em torno da imagem reproduzida do objeto do qual ele imaginariamente é colocado como compartilhador, rompendo as balizas do gozo simbólico. 


\section{CAPÍTULO V}

\section{ÚLTIMAS CONSIDERAÇõES}




\section{Um jeito diferente de dizer a mesma coisa.}

A disposição anatômica dos corpos-signos dos protagonistas nos ensaios fotográficos de G Magazine, em sua grande maioria, concede aos fotografados uma posição de domínio, de atividade perante o interlocutor que consome 0 produto.

O corpo-signo é objeto de desejo do espectador, ao mesmo tempo que também serve para a construção do processo de identificação deste, segundo Aumont. Este corpo-signo possui nas fotografias um discurso caracterizado pela demonstração de poder dos protagonistas, pela exibição do órgão genital que, imaginariamente, é lido como o falo faltante. O dono deste corpo é colocado como legitimamente ativo, dominante. Conforme Pierre Guiraud, o pênis ereto exibido é símbolo de demonstração de poder. O homem em G Magazine está lá para protagonizar tal exibição, presente em todos os ensaios publicados pela revista até hoje.

Quanto a esta linguagem do nu em G Magazine, nota-se um desequilíbrio numérico no que se refere às imagens publicadas nas quais a disposição anatômica do corpo do protagonista demonstra a possessão do poder em relação às imagens nas quais esta demonstração não ocorre. Nas 48 revistas editadas

entre janeiro de 2001 e dezembro de 2004, foram estampadas cerca de mil fotografias pertencentes aos ensaios dos protagonistas nas páginas da publicação. 
No meio dessas centenas de imagens, apenas uma sugere mais explicitamente o fotografado representando uma posição de passividade sexual em relação ao consumidor da revista. Esta peculiaridade em $G$ Magazine foi publicada na seqüência de um ensaio interno. Os mais 'famosos', que compõem os ensaios de capa, não aparecem em nenhum momento nas seqüências fotográficas em posições de passividade, como que oferecendo seu corpo ao observador para que este aceite um convite a dividir a cena ocupando uma posição de atividade sexual. A demonstração do poder do pênis é uma constante quase absoluta na revista.

Nas fotos com exibição do pênis ereto, o olhar estabelecido entre protagonista e espectador sugere um convite à passividade deste último, paralelamente à demonstração de poder do anterior. E este olhar do protagonista é dominador, cerceando a liberdade do observador, que 'se perde' libidinosamente na ilusória cumplicidade estabelecida entre ambos por intermédio deste olhar. Mas, esta mesma cumplicidade não se estabelece inversamente, quando o fotografado é focado de costas para a câmera, ou em qualquer posição que não denote sua atividade no ato sexual pela demonstração de poder do seu pênis.

Mesmo exibindo o dorso para a câmera, o protagonista em geral não se oferece para ser passivo em uma imaginária relação sexual com o espectador, posição que colocaria o exibicionista como não-detentor do poder: ele não seria o 
agente, aquele que exerce a ação, ou por meio da vontade do qual esta se faz. Em G Magazine, sendo o exibicionista uma representação do masculino, via de regra este não ocupa a posição passiva nas seqüências fotográficas que compõem os ensaios, o que reflete a estrutura do sistema. As posições hierárquicas e de valores da sociedade patriarcal, androcêntrica, são mantidas ao longo do discurso imagético da revista.

A linguagem utilizada por G Magazine, do corpo-signo masculino nu com exibição explícita do pênis ereto, é demonstração de certa liberdade de expressão no sistema, sem dúvida. A pornografia na revista trabalha a manifestação de prazeres proibidos ao sujeito, que busca a satisfação desta demanda pela partilha da exibição de um gozo. A fotografia pornográfica cristaliza representações de explícito teor sexual para o deleite do interlocutor, que sobre a imagem imaginariamente construirá uma significação com o auxílio de processos psíquicos e que lhe permitirá satisfazer a demanda reprimida socialmente.

Esta demanda reprimida é alimentada com uma linguagem de exibição de um gozo real, linguagem esta que, de forma geral, legitima a posição do masculino no eixo de poder, servindo de base para um discurso de fundo conservador. Este conservadorismo legitima uma estrutura já consagrada, colocando a imagem do protagonista, a figura do masculino, numa posição de domínio e de exibição do gozo pela posse deste poder. 
Durante nossa entrevista, a diretora de G Magazine Ana Maria Fadigas foi clara: "A $G$ é conservadora, o gay não é revolucionário". Desta forma, a principal responsável pelo direcionamento do discurso do veículo decretou que a $G$ Magazine - como também o seu público-alvo - não tem o intuito de revolucionar a estrutura consagradamente estabelecida.

Os discursos revolucionários têm em comum a idéia da construção de um novo sistema, de uma nova estrutura na qual o que se considera 'injustiça' na ordem estabelecida deixaria de ocorrer. Assim, por meio de uma revolução, a construção de "um novo mundo é possível" - conforme prega[va] o discurso do Fórum Social Mundial, evento que intenta se contrapor ao Fórum Econômico Mundial e, portanto, ao vigente sistema econômico, capitalista e globalizado, e que, segundo visões socialistas, seria a principal causa das imensas desigualdades sociais observadas hoje no mundo inteiro.

A sociedade contemporânea é culturalmente estruturada sob uma perspectiva sexual heterocêntrica, concedendo ao indivíduo heterossexual a posição central (portador do poder de decisão, do 'comportamento normal'), restando às demais nuances da sexualidade humana a posição à margem (fora do eixo de poder, com um 'comportamento dissonante'). E, ainda, nesta estrutura heterocêntrica, por meio de uma falsa aproximação do falo faltante com o pênis, o 
homem em posição sexual ativa é legitimado como central, por ser o possuidor do 'falo' e por utilizá-lo como ferramenta de demonstração e legitimação de seu papel. Aos demais humanos, que não exercem tal demonstração fálica de poder por questões anatômicas ou comportamentais, cabe o papel não-central.

Assim, numa estrutura social complexa, o homem ativo é 'estabelecido entre os estabelecidos'. Naturalmente, à imagem construída em torno deste signo (homem ativo) são outorgados os direitos de legítimos detentores do poder de decisão, cabendo a eles a grande maioria das principais posições para demonstração e exercício de poder nas mais diferentes esferas do sistema, em especial no Ocidente.

Pois é justamente a esta mesma imagem, a de um homem em posição ativa, que aludem as disposições anatômicas dos corpos-signos nos ensaios fotográficos de $G$ Magazine. A quase onipresença dos protagonistas em demonstrações de vigor físico e exibições de gozos tipicamente masculinos constrói a base do discurso da revista que, apoiado na fala de sua diretora, é absolutamente conservador.

Neste sentido, G Magazine é nada transgressora, anulando a possibilidade de construção de um discurso revolucionário no que se refere à hierarquia imposta pelo sistema, e especialmente ao lugar do homossexual. Nas páginas da revista o 
macho é o ativo, o sujeito que executa a ação, o que demonstra poder pela exibição do pênis ereto. 0 eixo do poder gira em torno dele, e o sistema deve por ele ser guiado.

O protagonista é o deus a ser adorado, e sua vontade deve ser executada. O seu corpo em evidência serve como objeto de veneração, concedendo a seu ostentador um poder divinizado. O masculino ativo é o eixo que faz girar o sistema, é quem ocupa o lugar do 'rei', daquele que decide, que manda, pois ele é portador deste símbolo máximo de superioridade, e o expõe com orgulho por meio de um discurso imagético de imposição deste poder. G Magazine, assim, mantém um discurso conservador, confirmado nas palavras da diretora da revista, Ana Maria Fadigas.

O sistema mantém, desta forma, seu eixo central de poder nas mãos do masculino ativo. O possuidor do pênis é legitimado como possuidor do poder, e a ele são outorgados o direito de domínio e a devoção idólatra da contemplação, como a confirmação do jogo entre poderes e prazeres mencionado por Foucault. Esta legitimação se processa por intermédio da leitura imagética dos ensaios fotográficos em G Magazine. Mantém-se, desta forma, o eixo de poder vigente no sistema desde muito tempo, não transgredindo junto à estrutura estabelecida de poder na sociedade. 
Os corpos-signos, por serem imagens de forte apelo de consumo em uma cultura profundamente visual e consumista, tornam-se poderosas ferramentas com capacidade de persuasão de um público que prefere um acesso mais direto ao objeto (uma imagem) que uma simples representação deste (como palavras). Os corpos-signos estampados nas páginas da revista dizem, com uma linguagem diretamente ligada à sexualidade, que o poder pertence ao homem ativo, ostentador de um símbolo máximo de devoção imaginária: o pênis, comumente confundido com o falo faltante, confusão esta que dá sustentação à masculinidade como ocupante da posição central no eixo de liderança do sistema. 


\section{Considerações finais.}

Por um lado, o espaço para as minorias dentro do sistema parece estar se abrindo, com oportunidades de manifestações para grupos outsiders tornando-se legítimas pela sociedade. Mas, quem está mais atento pode perceber que a movimentação não se direciona para uma abertura às diferenças, a não ser que estas diferenças possam se transformar em atrativo nicho de mercado. Se os outsiders não possuírem determinado poder de capital de giro para a economia de mercado, dificilmente conquistarão dos estabelecidos qualquer espaço para qualquer tipo de expressão.

No caso do público gay, além do fator acima, a crescente despolitização e conseqüente carnavalização da Parada do Orgulho Gay, por exemplo, remete-nos à idéia do desperdício de um possível espaço para vozes dissonantes que, engolido pelo mercado, torna-se interessante vitrine de negócios, um evento turístico que movimenta milhões de reais: para o comércio em geral pelo afã consumista, e para os cofres públicos na conversão de impostos. Com isso temos, na realidade, a perda da oportunidade de ouvirmos (ou mesmo de nos fazer ouvir) essas vozes realmente outsiders e que lutam pela modificação desta estrutura de poder, que se caracteriza pelo massacre daqueles que se posicionam fora do eixo das decisões. 
Por intermédio do seu discurso imagético, G Magazine, assim como a Parada do Orgulho Gay, parece deixar esta sensação de oportunidade perdida na construção de um espaço para as vozes dissonantes ou, numa liberdade poética, espaço para as imagens destoantes para o grupo estabelecido dentre os gays no Brasil. A linguagem do nu masculino, frontal e com ereção utilizada pela revista, que a princípio poderia introduzir um discurso transgressor contra a estrutura e os valores estabelecidos pelas amarras do sistema, parece apenas seguir a lógica do gozo consumista da nova economia psíquica.

A exibição do gozo, comportamento de lugar-comum hoje segundo Melman, constitui-se no carro-chefe de G Magazine. Após vencido o tabu 'religioso' referente ao pênis como objeto de divindade, o discurso agora é de oferecimento do gozo e da ilusão de posse do falo. A imagem do pênis é utilizada não como movimento transgressor, mas como conseqüência da nova economia psíquica, que tomou o lugar da economia do recalque religioso.

No que se refere ao discurso em $G$ Magazine, o conservadorismo apresentase como a tônica principal na construção do eixo de poder, fazendo eco às vozes mantenedoras do masculino como fonte divina de emanação da superioridade. 0 veículo não transgride, não se faz uma voz diferente em meio ao coro cultural que constrói imaginariamente o lugar do pênis, do seu possuidor, de sua exibição 
explicita como demonstração de poder e da legitimação da leitura equivocada do pênis como o equivalente ao falo faltante.

A figura do homem oferecido para consumo de $G$ Magazine ocupa sexualmente a posição ativa, culturalmente já ocupada pelo masculino na sociedade. A posse do pênis como signo de virilidade, que socialmente suporta a masculinidade, é exibida nos ensaios fotográficos da revista almejando cumprir o mesmo objetivo: referendar a hierarquia do macho como rei.

Por intermédio da linguagem do corpo, o veículo impõe a figura do masculino, do possuidor do pênis, como a legítima ostentadora do poder, do falo que a todos falta. O pênis, como um cetro, é o símbolo desta posição hierarquicamente superior aos demais humanos - àqueles que não ostentam poderio pela exibição do pênis ereto - e é exibido orgulhosamente, como a comprovação da virilidade, da potência.

G Magazine, à primeira vista um veículo totalmente aberto às discussões voltadas ao tema da igualdade de direitos à diversidade sexual, não consegue imageticamente representar esta igualdade sem preconceitos em seus ensaios. Os homossexuais masculinos sexualmente passivos estão excluídos da linguagem utilizada pelo veículo. Neste sentido, a revista faz coro ao discurso hegemônico do patriarcado, do poder nas mãos do macho ativo, dominante. 
PÁGINA 32

G Magazine. São Paulo, n. 84, capa, set. 2004.

PÁGINA 48

G Magazine. São Paulo, n. 84, p. 30-1, set. 2004.

PÁGINA 93

G Magazine. São Paulo, n. 52, p. 46, jan. 2002.

PÁGINA 110

G Magazine. São Paulo, n. 72, p. 36, set. 2003.

PÁGINA 120

G Magazine. São Paulo, n. 43, p. 34-9, abr. 2001.

PÁGINA 121

G Magazine. São Paulo, n. 43, p. 40-5, abr. 2001.

PÁGINA 122

G Magazine. São Paulo, n. 43, p. 46-51, abr. 2001.

PÁGINA 129

G Magazine. São Paulo, n. 77, p. 61, fev. 2004.

PÁGINA 133

G Magazine. São Paulo, n. 68, p. 37, mai. 2003. 


\section{REFERÊNCIAS BIBLIOGRÁFICAS}

AUMONT, Jacques. La imagen. Barcelona: Ediciones Paidos, 1992.

BAEZA, Pepe. Por una función crítica de la fotografía de prensa. Barcelona: Editorial Gustavo Gili, 2001.

BALBURE, Brigitte. Dicionário de Psicanálise: Freud e Lacan. Salvador: Ágalma, 1994.

BARTHES, Roland. A câmara clara: nota sobre a fotografia. Rio de Janeiro: Nova Fronteira, 1984. . Elementos de Semiologia. São Paulo: Cultrix, 1989.

BAUDRILLARD, Jean. $A$ sociedade de consumo. Lisboa: Edições 70, 2000.

BERGER, John. Modos de ver. Rio de Janeiro: Rocco, 1999.

BOURDIEU, Pierre. O poder simbólico. 6. ed. Rio de Janeiro: Bertrand Brasil, 2003.

BUITONI, Dulcilia. Aids: falas e silêncios em revistas masculinas e femininas. Revista USP, São Paulo, n. 33, p. 148-57, 1997.

. Imprensa feminina. 2. ed. São Paulo: Ática, 1990.

. Mulher de papel: a representação da mulher na imprensa brasileira. São Paulo: Loyola, 1981.

CASTORIADIS, Cornelius. A instituição imaginária da sociedade. São Paulo: Paz e Terra, 1986.

CESAROTTO, Oscar Angel. O discurso lacaniano. Viver Mente\&Cérebro - edição especial Memória da Psicanálise. São Paulo, v. 1, n. 4, p. 23-9, 2005.

COURTÉS, Joseph \& GREIMAS, Algirdas Julien. Dicionário de Semiótica. São Paulo: Cultrix, 1979.

DEBORD, Guy. A sociedade do espetáculo. Rio de Janeiro: Contraponto Editora, 1997.

DUBOIS, Philippe. O ato fotográfico e outros ensaios. 8. ed. Campinas: Papirus, 2004. - (Série Ofício de Arte e Forma). 
ECO, Umberto. Apocalípticos e integrados. 2. ed. São Paulo: Perspectiva, 1979.

EILBERG-SCHWARTZ, Howard. O falo de Deus e outros problemas para o homem e o monoteísmo. Rio de Janeiro: Imago, 1995.

ELIAS, Norbert e SCOTSON, John. Os estabelecidos e os outsiders. Rio de Janeiro: Jorge Zahar, 2000.

FOSTER, Hal. Recodificação - arte, espetáculo, política cultural. São Paulo: Casa Editorial Paulista, 1996.

FOUCAULT, Michel. A ordem do discurso. São Paulo: Loyola, 1996. . História da Sexualidade. Vol. I-A vontade de saber. 15. ed. Rio de Janeiro: Graal, 2003a.

. História da Sexualidade. Vol. II - O uso dos prazeres. 10. ed. Rio de Janeiro: Graal, 2003b.

. História da Sexualidade. Vol. III - O cuidado de si. 7. ed. Rio de Janeiro: Graal, 2002a. . Vigiar e punir. 26. ed. Petrópolis: Vozes, 2002b.

FREITAS, Jeanne Marie Machado de. Comunicação e Psicanálise. São Paulo: Escuta, 1992.

FREUD, Sigmund. "O mal-estar na civilização". In: Obras psicológicas completas de Sigmund Freud. Vol. XXIII. Rio de Janeiro: Imago, 1974.

GIL, José. A imagem nua e as pequenas percepções. Lisboa: Relógio D'água, 1996.

GUIRAUD, Pierre. A linguagem do corpo. São Paulo: Ática, 1991. - (Série Fundamentos; 70).

JOHNSON, Richard. "Estudos Culturais: uma introdução". In: SILVA, Tomaz Tadeu da (org.). O que é, afinal, Estudos Culturais?. Belo Horizonte: Autêntica, 2000.

KEHL, Maria Rita e BUCCI, Eugenio. Videologias. São Paulo: Boitempo, 2002. . "Masculino/feminino: o olhar de sedução". In: NOVAES, Adauto (org.). O olhar. São Paulo: Companhia das Letras, 1995. 
KOSSOY, Boris. Realidades e fiç̧ões na trama fotográfica. Cotia: Ateliê Editorial, 1999.

LACAN, Jacques. Escritos. São Paulo: Perspectiva, 1992a.

. Seminário XI: Os quatro conceitos fundamentais da Psicanálise. Rio de Janeiro: Jorge Zahar, 1998.

. Seminário XVII - O avesso da Psicanálise. Rio de Janeiro: Jorge Zahar, $1992 b$.

LAPLANCHE \& PONTALIS. Vocabulário da Psicanálise. São Paulo: Martins Fontes, 1995.

MACHADO, Arlindo. A ilusão especular: introdução à fotografia. São Paulo: Brasiliense, 1984.

MARTÍN-BARBERO, Jesús. Dos meios às mediações: comunicação, cultura e hegemonia. 2. ed. Rio de Janeiro: Editora UFRJ, 2003.

MELMAN, Charles. O homem sem gravidade: gozar a qualquer preço. Rio de Janeiro: Companhia de Freud, 2003.

MICHELET, Jules. La Sorcière. França: Flammarion: 1966.

MILLER, Gerárd (org.). Lacan. Rio de Janeiro: Jorge Zahar, 1999.

MOTTA, Luiz Gonzaga (org.). Imprensa e poder. Brasília: Editora UnB, 2002.

MOUSSEAU, Jacques. Dicionário do inconsciente. São Paulo: Verbo, 1984.

NOVAES, Adauto (org.). O olhar. São Paulo: Companhia das Letras, 1995.

RYCROFT, Charles. Dicionário crítico de Psicanálise. Rio de Janeiro: Imago, 1975.

PEIRCE, Charles Sanders. Semiótica. São Paulo: Perspectiva, 1977.

SANTAELLA, Lucia. As três categorias peirceanas e os três registros lacanianos. Revista de Psicologia da USP. São Paulo, v. 10, n. 2, p. 81-91, 1999.

- Da cultura das mídias à cibercultura: o advento do pós-humano. Revista FAMECOS. Porto Alegre, n. 22, p. 23-32, dez. 2003a. 
. Matrizes da linguagem e pensamento: sonora, visual, verbal. São Paulo: Iluminuras, 2001.

. O que é Semiótica. São Paulo: Brasiliense, 2003b. - (Coleção

Primeiros Passos; 103).

e NÖTH, Winifried. Imagem: cognição, semiótica, mídia. 4. ed. São Paulo: Iluminuras, 2005.

SARTRE, Jean-Paul. O ser e o nada. Ensaio de ontologia fenomenológica. 13. ed. Petrópolis: Vozes, 2005.

SCALZO, Marilia. Jornalismo de revista. São Paulo: Contexto, 2003.

SILVA, Tomaz Tadeu da (org.). Identidade e diferença. A perspectiva dos Estudos Culturais. Petrópolis: Vozes, 2000.

SONTAG, Susan. Ensaios de fotografia. Rio de Janeiro: Arbor, 1981.

TOMÉ, Eunice. O corpo da mulher: verdades e mitos sobre $o$ ato fotográfico na revista 'Playboy'. Dissertação de Mestrado, ECA/Universidade de São Paulo, 2002.

ZIMERMAN, David. Vocabulário contemporâneo de Psicanálise. Porto Alegre: Artmed Editora, 2001. 